Revised and resubmitted to Quaternary International on 21 June 2015

\title{
Formal subdivision of the Quaternary System/Period: past, present, and future.
}

\author{
Martin J. Head ${ }^{\text {a, }}$, Philip L. Gibbard ${ }^{\text {b }}$ \\ ${ }^{a}$ Department of Earth Sciences, Brock University, 500 Glenridge Avenue, St. \\ Catharines, Ontario L2S 3A1, Canada \\ ${ }^{\mathrm{b}}$ Cambridge Quaternary, Department of Geography, University of Cambridge, \\ Downing Place, Cambridge CB2 3EN, UK \\ * Corresponding author \\ E-mail address: mjhead@ @rocku.ca (M. J. Head) \\ Key words: Quaternary, Pleistocene, Holocene, Anthropocene, GSSP
}

\begin{abstract}
The Quaternary System/Period represents the past 2.58 million years and is officially subdivided into the Pleistocene and Holocene series/epochs, with the base of the Holocene assigned an age of 11,700 calendar years before AD 2000. The two lowest stages of the Pleistocene, the Gelasian (base 2.58 Ma) and the Calabrian (base 1.80 Ma), have been ratified and these effectively constitute the Lower Pleistocene Subseries. All other official subdivisions are pending. For the Middle Pleistocene, three candidate global boundary stratotype sections and points (GSSPs) are under consideration: the Valle di Manche in Calabria and Montalbano Jonico in Basilicata, both in southern Italy, and the Chiba section in Japan. The Matuyama-Brunhes Chron boundary ( $773 \mathrm{ka})$ serves as the principal guide for the base of the Middle Pleistocene. The base of the Upper Pleistocene is generally agreed coincide approximately with that of the last interglacial (Marine Isotope Substage 5e 130 ka): the Fronte section near Taranto in southern Italy represents a possible candidate GSSP, but an Antarctic ice core might also serve this purpose. Another important task is the subdivision of the Holocene for which a tripartite scheme, with boundaries at 8200 and 4200 years B.P., has been suggested. Additional fine-scale formal subdivision of the Quaternary is being explored, with the Last Glacial Maximum serving as a good example. The "Anthropocene" is both an informal and undefined interval of time that includes the present day. Its duration, formal/informal status, rank, and method of definition are all under debate, with proponents suggest that it be defined as a formal unit beginning with the world's first nuclear bomb explosion, on July 16th 1945. Suggested and proposed GSSPs are compared and critiqued. The history leading to the ratification of the Quaternary Period in 2009 is examined drawing upon published and unpublished material.
\end{abstract}




\section{Introduction}

The Quaternary Period/System represents the past $2.58 \mathrm{Ma}$ and is officially subdivided into the Pleistocene and Holocene series/epochs. The Quaternary Period/System, Pleistocene Series/Epoch, and Gelasian Stage/Age are all defined by a global boundary stratotype section and point (GSSP) at Monte San Nicola in Sicily (Gibbard and Head, 2010; Gibbard et al., 2010; Fig. 1). The Pleistocene is traditionally subdivided into Lower, Middle, and Upper Pleistocene subseries/subepochs, and although these subdivisions are not yet officially defined, the Calabrian Stage has been defined by the Vrica GSSP in Calabria, southern Italy, effectively completing the definition of the Lower Pleistocene (Cita et al., 2012). The Holocene is defined by a GSSP in the Greenland NGRIP ice core (Walker et al., 2009). No other GSSPs have yet been designated for the Quaternary. The current official time scale for the Quaternary, as sanctioned by the International Union of Geological Sciences (IUGS), including both ratified and suggested and proposed GSSPs, is shown in Figure 2.

We draw a distinction between the terms "formal" and "official" with respect to chronostratigraphic units. Here, "formal" refers to a unit whose boundaries are widely understood and accepted, whereas "official" refers to a unit whose lower boundary is defined by a GSSP proposed by the International Commission on Stratigraphy (ICS) and ratified by the Executive Committee (EC) of the IUGS. In this sense the Lower, Middle and Upper Pleistocene subseries are formal but not official units; the Holocene Series is both.

The objective is for all major boundaries of the Quaternary System to be defined by GSSP. This requires recommendations to pass up through a "chain of command".

The initiative begins with the Subcomission on Quaternary Stratigraphy (SQS), one of currently 16 constituent subcommissions of the ICS. The SQS establishes an international boundary working group (officially an ICS “task group"), led by a convener, and tasked with proposing a GSSP. This task itself is preceded by a decision by the working group on the primary guide to be used for the boundary. The primary guide might be a paleomagnetic boundary, or a geochemical excursion, or a paleontological event, or some other marker that can be recognized widely, and its selection will determine the appropriateness of a candidate GSSP, which is why such a decision is taken first (the principle of "correlation precedes definition"; Cowie, 1986; Cowie et al., 1986; Remane et al., 1996). The boundary must satisfy several criteria. As a first priority, it must facilitate global correlation. It should also reflect the narrative of Earth history by separating one chapter in that story from another, while respecting historical usage as far as is reasonable. Once the primary guide has been decided, the best stratotype is sought. In reality, multiple criteria are used to recognize a boundary, and a candidate GSSP ideally will display these in a well exposed, expanded, and accessible section. The full range of ideal criteria is listed in Table 1. A decision on whether to recommend a particular candidate GSSP is made first by the relevant boundary working group (officially a "task group"), next the SQS, and subsequenly the full voting membership of the ICS, this being the ICS executive and the chairs of the constituent subcommissions. A $60 \%$ supermajority is needed for a GSSP proposal to proceed to the next level, and at any level the proposal can be returned for clarification or revision. 
Once approved by ICS, a proposal is forwarded to the executive committee of the IUGS for ratification, which is granted only after final scrutiny especially to ensure that correct procedures have been followed. Immediately ratification is granted, the candidate GSSP has full legitimacy as a chronostratigraphic standard.

In spite of steady progress achieved over the past seven years in subdividing the Quaternary, much work remains to be done. This includes defining the Middle and Upper Pleistocene, subdividing the Holocene, and resolving the issue of the Anthropocene. Consequently, it seemed timely to organize a special session on "The Quaternary System and its formal subdivision" at the First International Congress on Stratigraphy, STRATI 2013, held in Lisbon, Portugal, during 1-7 July, 2013 (Rocha et al. (2013). Most of the papers presented are included in this special volume. The full-day session was sponsored by the ICS Subcommission on Quaternary Stratigraphy (SQS), which is charged with recommending Quaternary GSSPs to the ICS, and the Stratigraphy and Chronology Commission of INQUA (SACCOM). It was convened by Martin J. Head (Chair, SQS), Philip L. Gibbard (President, SACCOM), and Thijs van Kolfschoten (Secretary, SACCOM). Further details are given in the guest editorial (Head et al., this volume).

The present paper documents the fraught and tortuous history of the Quaternary as an official period/system (below, Table 2, and Appendices 1 and 2), comprehensively reviews its formal subdivision, and examines the tasks and challenges that lie ahead. In doing so, we have attempted to place the various contributions of this special volume within a broader context.

\section{The status and base of the Quaternary System/Period (2.58-0 Ma)}

\subsection{Initial phase: $1759-1854$}

The Quaternary was first introduced by the mining engineer Giovanni Arduino in 1759 (Arduino 1760), as a "fourth order" (quarto ordine) in his fourfold (chrono)lithostratigraphic subdivision of geological time, based on his observations of the Venetian and Tuscan regions of Italy. This "fourth order" comprised alluvial deposits, some of which were stratified, that he observed on the Po plain. Although he never actually used the term "quaternario", this concept has been used for 255 years (Vaccari, 2006; Head et al., 2008a). It was Desnoyers (1829, p. 193) who applied the term Quaternaire or tertiaires récens to strata of the Loire, Gironde, Hérault, and Rhône basins and in Italy that were younger than the "older Tertiary" of the Seine (Paris) Basin (Bourdier, 1957, p. 99; Farrand, 1990; Berggren, 1998), although he used this term only for brevity and ironically waived it in the same publication because of its transitional nature with the "older Tertiary" (footnote to p. 193 in Desnoyers, 1829). De Serres (1830) considered the Quaternaire synonymous with the term Diluvium, and noted that humans were contemporaneous with these deposits. It was finally defined on paleontological grounds in 1833 by $\mathrm{H}$. Reboul who remarked "This is why one had to call quaternary, the subsequent period, which is characterised by plant and animal species similar to those that occur in the same places today" (Reboul, 1833, p. 1, 2). Reboul credited Desnoyers as being first to use the term Quaternaire, which he used 
unequivocally to distinguish from the Tertiary. The extent of the Quaternary was vaguely and variably applied in these early usages (Berggren, 1998).

In the early $19^{\text {th }}$ century, prompted by Louis Agassiz's then new Glacial Theory (Agassiz, 1840, 1841), widespread erratics in Alpine and northern Europe were seen as having been deposited by extensive ice; and deposits comprising sands, gravels and boulder clays (previously labeled as "Diluvium" under the belief that they were the product of a Biblical flood or deluge) were attributed to deposition from floating ice and hence called "Drift" (Harland et al., 1982). Consequently, the Quaternary became synonymous with what Goethe had termed the Ice Age (Pillans and Gibbard, 2012), and indeed Morlot (1854/56) defined and subdivided his Quaternary on the basis of glaciation. Incidentally, Morlot (1859) introduced the term Quartaire (an "r" before the "t") as being more etymologically apt, given that "quaternary" refers to something composed of four parts, and indeed the German Quartär and Swedish kvartär capture the more appropriate spelling of Quaternary (Farrand, 1990).

In spite of the long ensuing usage of the Quaternary, the validity of the Quaternary as a chronostratigraphic unit came to be questioned by some stratigraphers on account of its early conceptualization as a climatostratigraphic unit. This objection did not apply to the Pleistocene, a term introduced informally by Lyell (1839) as an abbreviation for his Newer Pliocene, and based on biostratigraphic criteria (more than $70 \%$ of marine molluscs still living). Indeed, Lyell, who took 25 years to embrace his term Pleistocene formally (Lyell, 1873), determined it to be equivalent to the older strata of Desnoyers' Quaternary (Lyell, 1839; Lourens et al., 2005). Hence, the base of the Pleistocene and that of the Quaternary became inextricably linked over time. Forbes (1846) meanwhile had proposed equating the term Pleistocene (or Glacial Epoch) with the Diluvium, thus linking the Pleistocene with glaciation as had already been done for the Quaternary.

The term Quaternary became firmly established during the late 19th century and throughout the 20th century, as described in detail by Walsh (2008).

\subsection{Middle phase: $1948-2000$}

The linkage between the base of the Pleistocene and that of the Quaternary was reaffirmed during the 18th International Geological Congress in London in 1948, where it was agreed to place the "Pliocene-Pleistocene (Tertiary-Quaternary) boundary ... at the horizon of the first indication of climatic deterioration in the Italian Neogene succession." (King and Oakley, 1949a, p. 186). As an aside, later authors (e.g. Lourens, 2008) were to use this statement as implication that King and Oakley indended the Neogene to extend above the Tertiary-Quaternary boundary, although this interpretation was refuted by Walsh (2006, p. 214-215). When the Pleistocene GSSP was eventually established, in Vrica, Calabria, southern Italy, in 1985 (Bassett, 1985), this guiding principle was upheld (Aguirre and Pasini, 1985) and the boundary was placed at the top of the sapropelic layer "e", just below the lowest occurrence of the ostracode Cytheropteron testudo, which was considered to be a "northern guest" in the Mediterranean (Aguirre and Pasini, 1985; see Section 4, below). The Vrica GSSP is presently dated at $1.8 \mathrm{Ma}$.

The question of the Quaternary was set-aside during deliberations on the base of the Pleistocene (Aguirre and Pasini, 1985), presumably because several authors (e.g., 
Berggren and Van Couvering, 1974) had already advocated extending the Neogene to the present. The rationale for this position was the belief that when Hörnes (1851) coined the term "Neogene", he intended it to extend to the Holocene, which would have included the Quaternary. However, Hörnes seems not to have intend his Neogene to extend this far (Walsh, 2008 but see McGowran et al., 2009 for an alternative interpretation), but more importantly by the end of the $19^{\text {th }}$ century the term had widely come to refer exclusively to the Miocene and Pliocene and therefore exclude the Pleistocene and Quaternary (Walsh, 2008). Claims that the Quaternary lacked legitimacy because it had not been defined using marine biochronological criteria, and that the term is part of an outmoded and inappropriate nomenclature (e.g., Berggren and Van Couvering, 1974; Berggren, 1998; Aubry et al, 2005), were later dismissed (Walsh, 2008; Head et al., 2008; Appendix 2 , point 1 ).

The omission of the Quaternary from the definition of the Pleistocene was particularly remarkable because the effort made by the "IGCP [International Geological Correlation Program] working group that did much of the work leading to the formal proposal on the Vrica stratotype (approved at the 1982 INQUA Congress) was designated for the Neogene-Quaternary Boundary, not for the Pliocene-Pleistocene Boundary (IGCP Project 41, Neogene-Quaternary Boundary). The proposal sent to ICS referred consistently to the Neogene-Quaternary Boundary-stratotype.” (INQUA EC, 2005). The work of IGCP Project 41 and the Neogene-Quaternary Boundary is discussed by Nikiforova and Alekseev (1997).

Meanwhile, there had always been objections over the placement of the PliocenePleistocene boundary at Vrica on grounds that significant cooling had occurred earlier, at around 2.6 Ma (reviewed in Bowen and Gibbard, 2007; Head et al., 2008a). In order to resolve the question of the Vrica GSSP, a small ad-hoc committee consisting of three members each of the SNS and SQS was established in 1996 by the IUGS EC. However, by 1997 this committee had failed to reach a solution. The matter was then returned to the ICS, which duly held a ballot in 1998 comprising the full voting membership of both the SNS and SQS. The issue was whether to maintain the Pliocene-Pleistocene boundary at Vrica, or to lower it to the Gauss-Matuyama boundary. Although the normalized vote (50.1\% yes, $2.2 \%$ abstain, $47.8 \%$ against) was in favour of lowering the boundary, the requirement of a supermajority (60\% or more) was not met (Remane and Michelsen, 1998). But by not involving the entire ICS voting membership, it would have been difficult to achieve a supermajority decision in spite of the claim by Remane and Michelsen (1998) that bipartisan voting between SNS and SQS was not a significant issue. The status quo for theVrica GSSP was accordingly reaffirmed by the IUGS EC (in January 1999), and a 10-year moratorium then applied following ICS guidelines (Remane, 1996). Ironically, just a few years before, in 1996, the Gelasian Stage had been ratified as the highest stage of the Pliocene on grounds of major cooling and because the historical Piacenzian ranged no higher than its base (Rio et al., 1998). This in hindsight was a missed opportunity to lower the Pliocene-Pleistocene boundary, define the Quaternary, and circumvent the many problems that were to follow (see also Bowen and Gibbard, 2007).

This moratorium delayed progress in formalizing the Quaternary, although it continued to be used extensively as a unique and necessary term comprising both the Pleistocene and Holocene. Indeed, the Quaternary significantly appeared as a 
period/system on the ICS/IUGS-sanctioned global stratigraphic chart published in 1989 (Cowie and Bassett, 1989) albeit with its base coincident with that of the Pleistocene, and similarly in the IUGS chart compiled by Remane (2000; Fig. 3a). Indeed, Remane et al. (1996) had already stated that the Quaternary was defined by a GSSP, albeit by association.

\subsection{Under threat: $2000-2008$}

It came as an unwelcome surprise, therefore, to many Quaternary researchers when the Quaternary was excluded as a formal unit from the influential Geologic Time Scale 2004 (GTS2004) published by Gradstein and Ogg (2004) and Gradstein et al. (2004, 2005) (Fig. 3b). This approach had in fact been aired two years earlier (Gradstein and Ogg, 2002) on grounds that it was essentially a climatostratigraphic unit. Up to this point, the division of Quaternary time had been the responsibility of the INQUA Commission on Stratigraphy. This commission also served as the de facto Subcommission on Quaternary Stratigraphy of ICS. Although it served two masters, the commission officers were appointed by INQUA. On 19 December 2001, the Commission Secretary, Philip Gibbard received an e-mail message from Davide Castradori (then vice-president of the Subcommission on Neogene Stratigraphy [SNS]) informing him that he was "now the Chairman of the WG [working group] on Pleistocene Subdivisions, organized under the umbrella of SNS after the decision by ICS to disband the Subcommission on Quaternary Stratigraphy (to say better: to transfer their task to SNS ...)". He continued: "I am asking you, on behalf of former SQS and present INQUA Commission on Stratigraphy, to suggest a few names to be incorporated in the new WG, so that the expertise of your group will be of advantage to the progress of the new WG". The intention was to merge the SNS and SQS and "to remove the antiquated name Quaternary from the Global Chronostratigraphic Scale" (Zachariasse, 2001). Since the decision to suppress the Quaternary and subsume the Pleistocene (and presumably the Holocene) into an extended Neogene Period had apparently already been made on 21 August, 2001, "the ICS proposal has since been accepted with open arms by the INQUA" (Zachariasse, 2001), but actually without informing INQUA until after the decision had been made. The news spread rapidly through the Quaternary community, angry exchanges culminating in the immediate resignation of Castradori as Neogene workinggroup chair on 2 January 2002. Something had to be salvaged from the terminological wreckage. With this goal in mind, initial discussions were held at Utrecht in May 2002 between Philip Gibbard and Thijs van Kolfschoten, representing INQUA, and the SNS chair Willem Jan Zachariasse and secretary Fritz Hilgen. Here it was agreed to consider the possible inclusion of the Quaternary as a climatic or chronostratigraphic sub-division of the Neogene, of uncertain status. On 14-16 June of that year, a meeting of the full ICS was convened in Urbino in Italy, Philip Gibbard being invited to represent INQUA. At the insistence of the IUGS, it was decided here to re-establish a new ICS Subcommission of Quaternary Stratigraphy (SQS), independent of INQUA, to oversee the discussion of the status, and possible definition of Quaternary and its divisions. Initially Philip Gibbard was asked to chair the Subcommission, but later the ICS Executive attempted to appoint others. However, pressure from INQUA, under its then president Nicholas 
Shackleton (letter dated 19 July 2002), led to agreement that Gibbard should be reappointed.

In spite of these developments, the GTS2004 book extended the Neogene Period to the present day, and the Quaternary was relegated to the status of an unranked and essentially informal chronostratigraphic unit. Gradstein et al. (2004, table 1) noted that "the Quaternary is traditionally considered to be the interval of oscillating climatic extremes (glacial and interglacial episodes) that was initiated at about 2.6 Ma, therefore encompasses the Holocene and Pleistocene epochs and Gelasian Stage of Late Pliocene. This composite epoch is not a formal unit in the chronostratigraphic hierarchy". GTS2004 published in Gradstein et al. (2005) and the geological time scale charts included in Gradstein and Ogg (2004) and Gradstein et al. (2004) all claimed to be issued under the auspices of the ICS, but in reality they breached ICS's own statutes with regards to the treatment of the Quaternary (Finney, 2010) and therefore lacked official authority in this regard. Nonetheless, they exposed the need to resolve the question of the status, rank and duration of the Quaternary, and several options were illustrated by Ogg (2004).

As a compromise, Pillans (2004) proposed that the Quaternary be defined as a subperiod/subsystem, with its base at the pre-existing GSSP for the Gelasian Stage (uppermost stage of the Pliocene) at 2.6 Ma (see also Pillans and Naish, 2004; Fig. 3c). However, this would have accepted a lengthened Neogene Period/System, extending to the present day, and decoupled the base of the Quaternary from that of the Pleistocene (then at $1.8 \mathrm{Ma}$ ). It would have creating a "composite" unit spanning both the Pliocene and Pleistocene and thus violated the hierarchical principles of the time scale. Moreover, the INQUA Executive Committee had already expressed its interim preference for the Quaternary to remain as a period/system, separate in duration from the Neogene and comprising both the Pleistocene and Holocene (Pillans and Naish, 2004, p. 2274), albeit with a base at $1.8 \mathrm{Ma}$ (the status quo; Fig. 3a). A well-attended open SQS business meeting, held during the 32nd International Geological Congress in Florence in August 2004, overwhelmingly rejected the Pillans (2004) proposal, and affirmed the prevailing support for the Quaternary as a system/period, as did an email survey reported by the International Subcommission on Stratigraphic Classification (ISSN, 2004). As noted by M. Cita (ISSN, 2004, p. 18), if the Quaternary is a climatostratigraphic unit, then so is the Ediacaran System, which is defined not by the Ediacaran biota itself but by the top of the Marinoan (Varanger) glaciation. The INQUA Executive Committee, moreover, found widespread support for defining the Quaternary at 2.6 Ma. To resolve the Quaternary controversy, a joint ICS-INQUA Task Group (initially task force) was struck in November 2004, with a remit to report its recommendations to an ICS meeting in Leuven in September 2005. However, by March 2005, this group had not met, so a discussion meeting including most of the members of the Task Group was held in Cambridge on 24 March 2005. Here it was unanimously agreed that the Quaternary should be retained as a formal chronostratigraphic unit, a broad consensus that it should have full system status, and begin at $2.6 \mathrm{Ma}$, with the proviso that the marine community would find it difficult to move the base Pleistocene from its current 1.8 Ma position and that this would lead to a decoupling from the base of the Quaternary at 2.6 Ma. This solution, although nonhierarchical, was then seen as the best compromise (Gibbard, 2005). Following a series of votes, the Task Group finalized its report on August 2005, with the recommendations 
to the ICS and INQUA that the Quaternary should 1) be recognized as a formal chronostratigraphic/ geochronologic unit, 2) have its base defined by the Gelasian GSSP (at 2.6 Ma), and 3) have the rank of: a) System/Period (following Pillans, 2004), or b) Sub-erathem/Sub-era (following Aubry et al., 2005).

The response from the INQUA EC on 31 August was prompt, decisive, and reflected an insistence: that the Quaternary must be retained as a formal chronostratigraphic term, and that the current situation is that the Quaternary is unarguably a Period above the Neogene. It requested the establishment of a joint ICSINQUA working group to redefine the age of base of the Quaternary, from 1.8 to $2.6 \mathrm{Ma}$, proposing two solutions: 1) include the Gelasian Stage in the Pleistocene; (2) redefine the Gelasian as an Epoch between the Pliocene and Pleistocene (INQUA EC, 2005).

With INQUAs position at hand, the recommendations of the Task Group were discussed and voted upon during the ICS workshop in Leuven, Belgium, in September. The outcome of this meeting was that the Quaternary should indeed be recognized as a formal chronostratigraphic/geochronologic unit, with its base defined by the Gelasian GSSP (at 2.6 Ma), but that its status should be that of Sub-erathem/Sub-era. This was considered to be the best compromise that would allow the Quaternary to exist as an official term, while satisfying the Neogene marine comminity. The votes were 12 yes, 5 no, and 1 abstain. In October 2005, shortly after the meeting, ICS submitted these recommendations to the INQUA EC for approval by its membership and also to the IUGS EC (Gradstein, 2005; Fig. 3d).

On December 7, 2005, the INQUA EC canvassed opinion on the ICS proposal among its members. On March 24, 2006, taking these responses into account, the INQUA EC communicated to the ICS its position, that: 1) the Quaternary must be full formal chronostratigraphic unit at the rank of Period (or System), 2) the base of the Quaternary should be defined by the Gelasian Stage GSSP, and 3) base of the Pleistocene should be lowered to 2.6 Ma, coincident with that of the Quaternary boundary. Moreover, INQUA noted that "the top of the Neogene has never been defined and [INQUA] therefore insist that ICS not extend it to the present. An attempt to do this would be a unilateral and hostile action to the Quaternary community". INQUA appreciated that the base of the Pleistocene could not be lowered until 2009 at the earliest owing to a 10-year statutory moratorium, but indicated that it could wait (INQUA EC, 2006). This was to be the final position of INQUA, and had indeed been the position of SQS since 2004 (the "Quaternary" proposal, Fig. 3h).

On 25 August 2006, the IUGS EC rejected the ICS recommendations on grounds that they did not respect the long-held principle of hierarchy inherent within the standard geological time scale, nor indeed ICS's own guidelines and protocols. The ICS was urged to maintain dialogue with INQUA and to meanwhile ensure that the Quaternary be depicted on its time scale charts as published by IUGS in 2000 (Remane, 2000), namely the Quaternary as a period with a base coincident with that of the Pleistocene at $1.8 \mathrm{Ma}$ (IUGS EC, 2006).

The IUGS EC in February 2007 rebuked the ICS over its "dysfunctional" operation including the mishandling of a variety of procedural issues, and expressed dissatisfaction with ICS's treatment of the Quaternary issue. It withheld financial support to ICS pending resolution of these issues (IUGS EC, 2007a). This prompted the ICS, on 14 April 2007, to conduct a new ballot on the Quaternary in which the following 
elements, assembled as a single proposal for voting, were approved by supermajority: 1) the Quaternary established as a full formal chronostratigraphic unit at the rank of Period/System, 2) the base of the Quaternary defined by the Gelasian Stage GSSP (at 2.6 $\mathrm{Ma}), 3$ ) the base of the Pleistocene lowered to coincide with that of the Quaternary boundary, and 4) the GSSP at Vrica (the former Pliocene-Pleistocene boundary) retained as the base of a newly defined Calabrian Stage, serving then as the second stage of the newly defined Pleistocene (Fig. 3f). This proposal was submitted to the IUGS EC on 13 May, 2007. The IUGS EC responded on 28 May 2007 that while it granted approval for the Quaternary to be recognized as a system/period, the proposed base of the Quaternary had not been subject to consultation, discussion, or separate voting and so could not be ratified by the IUGS EC. IUGS EC recommended that the matter not be rushed, that due process be followed especially with respect to the 10-year moratorium on the base of the Pleistocene (which was due to expire at the end of January 2009), and should be a key topic for discussion at the $33^{\text {rd }}$ International Geological Congress (IGC) in Oslo during August 2008 (IUGS EC 2007b). All the above correspondence is available online from the website of the Subcommission on Quaternary Stratigraphy (http://quaternary.stratigraphy.org/meetings/task.html). Meanwhile, in July-August, 2007, at the $17^{\text {th }}$ INQUA Congress in Cairns, Australia, approximately 700 delegates unanimously endorsed the SQS/INQUA position (INQUA, 2009; Fig. 3h).

\subsection{A fresh start with ICS under new management: 2008-2009}

The ICS under incoming Chair, Stanley C. Finney, organized an open discussion meeting on the Quaternary at the Oslo IGC. This meeting was chaired by Stanley Finney for ICS and John Clague (Past-President INQUA) for INQUA. It followed the session "Pliocene-Pleistocene correlations and global change" held earlier on the same day and at which presentations served as a basis for positions and arguments in the discussion meeting. Philip Gibbard as Chair of SQS opened presentations supporting the SQS/INQUA position, and Fritz Hilgen as Chair of SQS led presentations of alternative positions. Following the Oslo IGC, proponents were invited to submit formal proposals and supporting cases. Philip Gibbard and Martin Head submitted the "Quaternary" proposal (Fig. 3h), essentially providing justification for the SQS/INQUA position and supported by scientific arguments given by Head et al. (2008a). Fritz Hilgen and several coauthors submitted the counter "Neogene" proposal that would extend that system to the present (Hilgen et al., 2008; Fig. 3f). It was supported by alternative perspectives given by Aubry et al. $(2005,2009)$ and Lourens $(2008)$. The full texts of the "Quaternary" and "Neogene" proposals are reproduced in Gibbard and Head (2009a). The Neogene proposal (Hilgen et al., 2008) contained both a preferred option (Fig. 3f) and an alternative option (Fig. 3g), although only the preferrd option was to go forward for voting. The "Quaternary" and "Neogene" proposals were then voted upon and approved, overwhelmingly, by their respective subcommissions, and forwarded in December 2008 to the ICS voting membership for consideration (Finney, 2010). A period of intense open discussion via email and the ICS website was provided prior to voting. On 17 February 2009, the SNS submitted to Stanley Finney, as Chair of ICS, its objections to the "Quaternary" proposal. A rebuttal by Martin Head and colleagues on behalf of SQS was submitted to ICS on 27 February, 2009. These submissions represent the closing 
arguments for the SNS and SQS respectively and, having not been published previously, are reproduced herein (Appendices 1 and 2). Of the many other submissions received by ICS, one was a letter on behalf of the INQUA EC (2009) providing strong and unequivocal support for the "Quaternary" proposal, and reminding ICS that: 1) INQUA claims significant jurisdiction over the Quaternary Period, 2) INQUA and IUGS are equal partners under the International Council for Science (ICSU) [INQUA has been a full Scientific Union member of ICSU since 2005], 3) the 2007 INQUA Congress in Cairns, Australia, had unanimously endorsed the "Quaternary" proposal, and 4) the IUGS EC had already approved the ICS's own request that the Quaternary be accepted as a period/system, so this issue should not be subject to further voting.

Just prior to voting, the SNS asked to modify their proposal substantially but this was not permitted (Finney, 2010). A "status quo" proposal was included. The proposals as they appeared on the ballot form were as follows.

"Status Quo" Proposal: Pleistocene Series/Epoch remains defined by Vrica GSSP. The base of the Quaternary System/Period is formally defined also by the Vrica GSSP, corresponding to the base of the Pleistocene Series/Epoch and Calabrian Stage/Age, and serving also as the Neogene-Quaternary boundary (Fig. 3a).

"Quaternary" Proposal: Base of Pleistocene Series/Epoch is lowered such that the Pleistocene includes the Gelasian Stage/Age and its base is defined by the Monte San Nicola GSSP, which also defines the base of the Gelasian. In addition, the base of the Quaternary System/Period, and thus the Neogene-Quaternary boundary, is formally defined by Monte San Nicola GSSP and is coincident with the bases of the Pleistocene and Gelasian. With these definitions the Gelasian Stage/Age is transferred from the Pliocene Series/Epoch to the Pleistocene (Fig. 3f).

"Neogene" Proposal: Pleistocene Series/Epoch remains defined by Vrica GSSP. The Pliocene Series/Epoch is split into two series/epochs named Lower/Early Pliocene and Upper/Late Pliocene, with the later composed of the Gelasian Stage/Age and with its base defined by the Monte San Nicola GSSP. The rank of the Quaternary is changed from system/period to subsystem/subperiod; its base is formally defined by the Monte San Nicola GSSP. As a result, the Quaternary is composed of the Upper/Late Pliocene, Pleistocene, and Holocene series/epochs. The Neogene System/Period extends upwards such that it includes the Miocene, Lower/Early Pliocene, Upper/Late Pliocene, Pleistocene, and Holocene series/epochs (Fig. 3e).

Ballots were distributed on 24 March 2009, and results compiled on 22 April 2009. Only the "Quaternary" proposal achieved a supermajority. A second round of voting was then held within ICS in which the "Quaternary" proposal (Fig. 3h) alone was considered. An overwhelming majority of $89 \%$ approved the proposal. Full details of both rounds of voting are given in Gibbard and Head (2009a) and Finney (2010). ICS then forwarded the proposal to the IUGS EC on 2 June, and it was ratified by the IUGS EC on 29th June 2009 (Gibbard and Head, 2009b). Under ICS guidelines, revisions to a GSSP cannot normally be made until at least 10 years have elapsed, and then only under exceptional 
circumstances (Remane et al., 1996). Documents relating to ICS voting are archived on the SQS website at: http://quaternary.stratigraphy.org/Temporary\%20Items/

As a postscript, it should also be noted that the Tertiary remains an unresolved issue, with proponents recommending that it be reinstated as a period/system beneath and contiguous with Quaternary (Salvador, 1994; Salvador 2006a, b; Walsh, 2006, 2008; Head et al., 2008a, b; Fig. 3e). The Paleogene and Neogene would then revert to the rank of subperiod/subsystem. As far back as 2007, in the lead up to the 2008 IGC Congress in Oslo, the Secretary-General of the IUGS wrote to the ICS saying "IUGS now suggests that you follow the established protocol for defining the base of the Quaternary with due consideration and respect for the issue of the "Tertiary" (IUGS EC, 2007b)". The issue of the Tertiary regrettably, however, remains neglected. It must be remembered that, unlike the Quaternary controversy, there is no dedicated subcommission within ICS to lobby for the Tertiary: the initiative will need to come from outside, such as from a consortium of national geological societies and agencies.

Looking back over the five fraught years taken to reinstate and redefine the Quaternary, several key points become clear:

1. There was early and near unanimous consensus that the Quaternary should begin at $\sim 2.6 \mathrm{Ma}$, broadly in conjunction with the intensification of Northern Hemisphere glaciation. While this conceptually represents a climatic or paleoenvironmental event, the same in reality is true of many officially-defined chronostratigraphic units, including the original Pleistocene GSSP. The base of the Quaternary is, in any case, defined by a preexisting conventionally-defined GSSP (that of the Gelasian Stage).

2. The principle of hierarchy for the international geological time scale is sacrosanct. Lowering the Pliocene-Pleistocene boundary to the level of the base Quaternary was therefore inevitable once the base of the Quaternary was decided.

3. Vague historical concepts and definitions should not have been allowed to hinder progress, given that there is no regulation of formal priority in stratigraphy (Remane et al., 1996). Furthermore, there is no historical justification for extending the Neogene to the present day (Walsh, 2008).

4. A failure by the ICS EC to conduct its own business transparently and cooperatively and follow its own stated procedures (until 2008 when a new EC took over; Finney, 2010) contributed significantly to the delay in resolving the question of the Quaternary. Ironically, the initial failure by the ICS as far back as 2000 to acknowledge the legitimacy of the Quaternary exposed the need to deal with this and relates issues, and acted as a catalyst to bring about a final resolution.

5. Finally, owing to the principle of "base defines unit", the SQS always had primary responsibility over the nature of the base of the Quaternary.

\section{The GSSP for the Gelasian Stage, Pleistocene Series, and Quaternary System (2.58)}


The Gelasian Stage is now the lowest stage of the Quaternary, but was initially conceived as the highest stage of the Pliocene System (Rio et al., 1998). It is defined by the GSSP at the Monte San Nicola section, near Gela, in Sicily (Figs. 1, 4, 5), and was ratified by the IUGS EC in August 1996. The avowed motivation for establishing the Gelasian Stage was that: 1) no previously assigned standard stage covers the interval of time between the top of the historical Piacenzian and the Vrica GSSP (then the base of the Pleistocene); 2) the top of the historical Piacenzian falls at a critical point in the evolution of Earth's climate system, namely close to the final build-up of Northern Hemisphere glaciation; and 3) that there are multiple signals available for global correlation to establish a new stage (Rio et al., 1991, 1994, 1998). The GSSP occurs at the base of the marly layer overlying Mediterranean Precession Related Sapropel (MPRS) 250 (the "Nicola bed"; Fig. 5) which has a midpoint astrochronological age of 2.588 Ma. The GSSP itself, being positioned slightly above this midpoint, has an estimated age of 2.58 Ma (Gibbard and Head, 2009b). The GSSP corresponds to Marine Isotope Stage (MIS) 103, and is about $1 \mathrm{~m}$ above the Gauss-Matuyama boundary. The most useful marine biostratigraphic marker in lower latitudes is the highest occurrence of the nannofossil Discoaster pentaradiatus considered to be $\sim 80$ kyr above the boundary (Rio et al., 1998).

As noted by Lourens et al. (2005, p 417), "The Gelasian marks a crucial period in the evolution of Earth's ocean-climate system due to the occurrence of major obliquitycontrolled northern hemisphere glacial cycles", and it is for this reason that the base of the Quaternary at $\sim 2.6 \mathrm{Ma}$ was not seriously contested during the recent Quaternary controversy. In fact, while significant intensification of northern-hemisphere glaciation during the MIS G7-G6 (2.74 Ma) transition is well known, a major shift in the position of the North Atlantic Current occurred at MIS 104 ( 2.6 Ma) and suggests a major climatic reorganization within the Northern Hemisphere almost precisely at the base of the Quaternary (Hennissen et al., 2014).

\section{The GSSP for the Calabrian Stage (1.80 Ma)}

The Calabrian is the second stage of the Pleistocene. It is defined by the former Pleistocene GSSP at Vrica, Calabria, southern Italy (Aguirre and Pasini, 1985; Pasini and Colanongo, 1997; Fig. 1), and was ratified on 5 December 2011 (Cita et al., 2012). This GSSP was originally chosen to reflect cooling in the Mediterranean, as discussed above, although the major signals for cooling in the Mediterranean, and elsewhere, occur earlier (e.g. Head et al., 2008a; Gibbard and Head, 2010). For example, the cold-water ostracode Cytheropteron testudo has its lowest occurrence in the Vrica section just above the GSSP (Aguirre and Pasini, 1985), but this species has since been recorded from the Gelasian stratotype at Monte San Nicola locality in Sicily at around 2.4 Ma (Bonaduce and Sprovieri, 1985; Aiello et al., 1996, 2000; Pasini and Colanongo, 1997). Similarly, the cold-water mollusc Arctica islandica, the "most renown "northern guest"" and one of the main criteria for defining the base of the Pleistocene in the Mediterranean area (Aguirre and Pasini, 1985), had in fact been recorded at $2.0 \mathrm{Ma}$ in Italy (Arias et al., 1980). 
The GSSP is placed at the base of the marine claystone conformably overlying sapropelic bed 'e' (assigned to MPRS 176; Fig. 6), and has an estimated age of 1.80 Ma based on the astronomical age of $1.806 \mathrm{Ma}$ for the midpoint of sapropelic bed 'e' and allowing for the delay in deposition of the overlying claystone (Cita et al., 2012). The GSSP coincides with the transition from Marine Isotope Stage 65 to 64. The top of the Olduvai Subchron is identified $\sim 8 \mathrm{~m}$ above the GSSP, but diagenetic overprinting has obstructed efforts to locate the boundary more precisely (Roberts et al., 2010). Primary guides to global correlation are therefore marine isotope stratigraphy and magnetostratigraphy, with sapropel stratigraphy available for correlation throughout the eastern Mediterranean. Calcareous plankton bioevents are present as secondary markers (Cita et al. 2012).

\section{Subseries for the Pleistocene and Holocene series}

Subseries are not currently represented in the International Geological Time Scale, the closest comparison being the ratified subdivision of the Carboniferous System into Mississippian and Pennsylvanian subsystems. The ICS-sanctioned 1989 Global Stratigraphic Chart (Cowie and Bassett, 1989) shows subseries for the Miocene, Pliocene and Pleistocene, and although no subseries are shown in the IUGS chart of Remane (2000), they again appear in the (unofficial) GTS 2004 (Gradstein et al., 2004, 2005; Lourens et al., 2005; Gibbard and van Kolfschoten, 2005). However, GTS 2004 is inconsistent with regard to the Pliocene subseries, e.g., Piacenzian either as Late (with the Gelasian) or Middle Pleistocene.

The subdivisions Lower, Middle and Upper Pliocene were indicated in the respective definitions of the Zanclean (Van Couvering et al., 2000), Piacenzian (Castradori et al., 1998), and Gelasian (Rio et al., 1998), even though these subdivisions were not named explicitly as subseries. The Gelasian Stage is referred to the Upper Pliocene in Lourens et al. (2005) and Upper Pliocene or Lower Pleistocene in Hilgen et al. (2012).

The terms Lower, Middle, and Upper Pleistocene have been used quasi-formally since the 1930s, beginning with the Second INQUA Congress in Lenningrad 1932 (Woldstedt, 1962), although they may have been used loosely before then (Gibbard and van Kolfschoten, 2005). Zeuner $(1935,1959)$ and Hopwood (1935) were the first to use these terms in English in a formal sense, based on the European vertebrate record. In the former USSR and in Russia, essentially beginning with the Leningrad Congress, a parallel terminology evolved for the subdivision of the Quaternary (Anthropogene in the Russian literature), as reviewed by Gerasimov (1979) and Vangengeim (2010). The Pleistocene is divided into two subseries, the Eopleistocene (initially equivalent to the Calabrian Stage, now broadly equivalent to the Gelasian and Calabrian) and Neopleistocene (approximately equivalent to the Middle and Upper Pleistocene). The Neopleistocene has Lower, Middle and Upper subdivisions, the Upper Neopleistocene being exactly equivalent to the Upper Pleistocene (Vangengeim, 2010, fig. 2; Shik, 2014).

The Holocene Series has long been divided into three informal units, and in 2010 a Joint Working group of SQS and INTIMATE (Integration of ice-core, marine and 
terrestrial records, an INQUA International Focus Group) was established to explore whether the Holocene should be officially divided. The ensuing discussion paper proposed that indeed it should (Walker et al., 2012), and the current view is that the Holocene Series should be subdivided into three subseries and their corresponding stages.

\section{The Lower-Middle Pleistocene Subseries boundary (0.7 Ma)}

The Early-Middle Pleistocene transition (EMPT) is a major climatic transition in Earth's history occurring between 1.4 and $0.4 \mathrm{Ma}$ and characterized primarily by a progressive increase in the amplitude of climate oscillations and a shift from 41-kyr to quasi-100 kyr frequency. Changes during this transition are perhaps most intense near to its midpoint at around MIS 24-22 (900 ka) which is also close to the Matuyama-Brunhes boundary at $\sim 773 \mathrm{ka}$. The EMPT is reviewed by Head and Gibbard (submitted).

Although several several positions for the Early-Middle Pleistocene boundary have been suggested (see Head and Gibard, 2005 for discussion), support has been greatest for the Matuyama-Brunhes boundary. For example, participants at the Burg Wartenstein Symposium "Stratigraphy and Patterns of Cultural Change in the Middle Pleistocene, held in Austria in 1973, recommended that "The beginning of the Middle Pleistocene should be so defined as to either coincide with or be linked to the boundary between the Matuyama Reversed Epoch and the Brunhes Normal Epoch of paleomagnetic chronology" (Butzer and Isaac, 1975, appendix 2), and a similar conclusion was reached by the INQUA Working Group on Major Subdivision of the Pleistocene at the 12th INQUA Congress in Ottawa in 1987 (Richmond, 1996). The Matuyama-Brunhes boundary (MBB) has since been widely used in defining the EarlyMiddle Pleistocene boundary (e.g., Bowen, 1988; Berggren et al., 1995; Pillans, 2003; Gradstein et al., 2005; Head and Gibbard, 2005; Head et al., 2008c; Gradstein et al., 2012), and in their redefinition of Italian marine stages, Cita et al. (2006) and Cita (2008) proposed the Matuyama-Brunhes boundary as the guiding criterion for the base of the Ionian Stage.

At the 14th INQUA Congress in Berlin in 1995, the search for a suitable boundary stratotype section was narrowed to three sections in Japan, New Zealand, and Italy. However, the New Zealand section contained unconformities and was removed from consideration (Head et al. 2008c).

In 2002, a Working Group of SQS was established to review all aspects of the boundary, including its position within the EMPT and selection of a suitable GSSP. At the $32^{\text {nd }}$ International Geological Congress in Florence in 2004, the Working Group recommended that (Head et al. 2008c):

"1. The E-M Pleistocene boundary be defined in a marine section at a point 'close to' the Matuyama-Brunhes boundary. The definition of 'close' was agreed to mean within plus or minus one isotope stage of the MBB.

2. The GSSP should be located in a marine section exposed on land, not in a deep sea core." 
With respect to the principle of "correlation precedes definition" (Remane et al., 1996), these recommendations cemented the long-held tradition of accepting the MatuyamaBrunhes boundary as the primary guide for the Early-Middle Pleistocene boundary (Head and Gibbard, 2005; Head et al., 2008c).

Three candidate sections are presently being considered by the Working Group: 1. Montalbano Jonico section in Italy (Ciaranfi and D'Alessandro, 2005; Marino et al., this volume).

2. Valle di Manche section in Italy (Capraro et al., 2005; Scarponi et al., 2014; Capraro et al., this volume).

3. Chiba section in Japan (Kazaoka et al., this volume; Suganuma et al., 2015).

Of the first two, the Montalbano Jonico section is expanded relative to the Valle di Manche section, but diagenesis has compromised the magnetostratigraphy at Montalbano Jonico. All sections, however, have orbital stratigraphic control. Neither Mediterranean site has sapropel stratigraphy close to the boundary because sapropels were not developed in the Mediterranean at this time. Each candidate section is discussed in turn.

\subsection{Montalbano Jonico (Basilicata, southern Italy)}

Located in the Lucania Basin, a minor basin of the Bradano Trough, the Montalbano Jonico composite section is about $450 \mathrm{~m}$ thick and consists of marine-deposited muddy clays and muddy sands intercalated with nine volcaniclasic layers, V1 to V9 (Ciaranfi et al., 2010). The composite section is divided into two intervals, a lower interval A (MIS 36-23) which contains sapropel layers, and an upper interval B (MIS 22-16) that does not, with a gap of $<20 \mathrm{kyr}$ between the two intervals. The composite section spans an interval from 1240 to $600 \mathrm{ka}$, potentially allowing it to serve along with the Vrica section, with which it just overlaps, as a unit stratotype for the Calabrian Stage (Miaorano et al., 2010).

The Montalbano Jonico composite section (Fig. 1) is orbitally-resolved throughout using benthic marine oxygen isotopes augmented with marine biostratigraphy and radiometric dating of the volcaniclasic layers. The Montalbano Jonico composite section therefore has an exceptionally well-resolved chronology, is very well studied, and has very high sedimention rates $(0.5-2.0 \mathrm{~m} / \mathrm{ka})$ in the vicinity of MIS 19 (Ciaranfi et al., 2010; Marino et al., this volume).

Unfortunately the Matuyama-Brunhes boundary, the primary criterion for recognizing the Early-Middle Pleistocene boundary, is not recognized owing to late diagenetic remagnetization associated with the growth of greigite (Sagnotti et al., 2010). However, it is known to occur within MIS 19, and this part of the composite sectionbest exposed in the Ideale section (Fig. 7) - has been studied in exceptional detail for pollen (Bertini et al., this volume) and ostracodes (Aiello et al., this volume). In addition, the volcaniclastic layers V1-5 and 7 have been mineralogically characterized, and the V4 layer ${ }^{40} \mathrm{Ar} /{ }^{39} \mathrm{Ar}$-dated to $773.9 \pm 1.3 \mathrm{ka}$ (Petrosino et al., this volume). The V4 layer is significant because its age is close to the 770-773 ka age determined for the MatuyamaBrunhes boundary elsewhere (Suganuma et al., 2015; Head and Gibbard, submitted). It occurs in the upper part of MIS 19, and is questionably correlated with SUL2-16 (776.7 \pm 
$2.3 \mathrm{ka}$ ) of the Sulmona Basin in central Italy. However, no correlative layer has been found in the Valle di Manche section (below).

Latest research on the Ideale section shows the pollen stratigraphy and the paleodepth reconstruction from ostracodes to be in good accord with the benthic $\delta^{18} \mathrm{O}$ record, the paleodepth and temperate forest expansion both increasing just before the initial peak of MIS 19. Marino et al. (this volume) make the case that even without the previously agreed Matuyama-Brunhes boundary, the Montalbano Jonico composite section should still be considered for the GSSP on account of its highly resolved multiproxy characterization of MIS 19, high sedimentation rate, and presence of the precisely dated V4 volcaniclastic layer.

In summary, the positive features of the Montalbano Jonico composite section are:

1. Continuous marine sedimentation from 1240 to $600 \mathrm{ka}$.

2. Marine oxygen isotopes (benthic and planktonic) (MIS 36-16) recorded throughout.

3. Detailed marine biostratigraphy including foraminifera and nannofossils.

4. Detailed pollen stratigraphy across boundary interval.

5. Extensive published record of the composite section.

6. Very high sedimentation rates of around $0.5-2.0 \mathrm{~m} / \mathrm{kyr}$ in the Ideale section.

7. Nine tephra layers throughout, including V4 $(773.9 \pm 1.3 \mathrm{ka})$ that matches the age of the Matuyama-Brunhes boundary.

8. With the Vrica section, it could form a unit stratotype for Calabrian Stage.

9. The section has excellent preservation and access.

The negative feature is:

1. No magnetostratigraphy due to diagenetic overprinting.

\subsection{Valle di Manche (Calabria, southern Italy)}

The Valle di Manche section (Fig. 1, 8, 9), near San Mauro Marchesato, is located in a forearc basin known as the Crotone Basin that contains more than $3 \mathrm{~km}$ of Upper Miocene through Pleistocene deposits. The San Mauro area lies within a fault-controlled sub-basin that experienced persistent and high tectonic subsidence rates. The San Mauro succession extends from $\sim 1.5 \mathrm{Ma}$ to $\sim 0.3 \mathrm{Ma}$, becoming marginal- to non-marine from $\sim 0.65 \mathrm{Ma}$. The Valle di Manche section extends from MIS 23 to $\sim$ MIS 18.3 based on the interpretation of cyclothems. The ongoing work of Capraro et al. (this volume) updates an earlier study by Capraro et al. (2005; see also Rio et al., 1996; Massari et al., 2007; Scarponi et al., 2014) with a revised lithological log and higher-resolution sampling.

Particularly important features of this section are a detailed benthic marine isotope stratigraphy from MIS 21 to 18.4, detailed pollen analysis throughout, the identification of the Matuyama-Brunhes boundary, and the presence of a volcaniclastic layer (the "Pitagora ash" of Rio et al., 1996; Fig. 9) within 0.5-1.0 m of the MatuyamaBrunhes boundary. Unfortunately, the "Pitagora ash" is redeposited from an earlier ash layer, and therefore has no correlative value beyond the San Mauro sub-basin, and no potential for radiometric dating. It appears to be older than the V4 layer at Montalbano 
Jonico judging from its earlier position within MIS 19. Nonetheless, the "Pitagora ash" does enable the horizon of the Matuyama-Brunhes boundary to be traced within the subbasin, and its base has therefore been suggested for the position of the GSSP (Capraro et al., this volume). The sediment accumulation rate across the Matuyama-Brunhes boundary is estimated to be $\sim 13 \mathrm{~cm} / \mathrm{kyr}$ (Capraro et al., 2005).

The occurrence of the Matuyama-Brunhes boundary before the peak of MIS 19 is presently unexplained. A global survey of high-quality published records shows that the Matuyama-Brunhes boundary usually occurs after the peak of MIS 19 (Head and Gibbard, submitted). Paleobathymetry reconstructions based on benthic (mostly mollusc) macrofossils show peak water depth above the Matuyama-Brunhes boundary (Scarponi et al., 2014), in broad concurrence with the marine isotope stratigraphy. Furthermore, the pollen record is in phase with the marine isotope stratigraphy. Some discrepancies exist with the Montalbano Jonico pollen record, such as cool and wet (rather than arid) conditions during glacial phases of MIS 20 and 18.4, but local environmental and geographic factors seem to explain these discrepancies (Capraro et al., 2005; this volume).

Although not relevant to its prospects as a GSSP, the Valle di Manche section cannot be used with the Vrica section as unit stratotype for Calabrian Stage because there is a gap between their respective records: The Valle di Manche section begins at MIS 23 whereas Vrica ends at MIS 37 (Cita et al., 2012, fig. 7).

In summary, the positive features of the Valle di Manche section are:

1. Matuyama-Brunhes boundary recognized.

2. Continuous marine sedimentation from 900 to $\sim 750 \mathrm{ka}$ (MIS 23 to $\sim \mathrm{MIS} 18.3$ ) based on the interpretation of cyclothems.

3. Marine oxygen isotopes (benthic and planktonic) recorded from MIS 21 to 18.4.

4. A moderately high sedimentation rate of $\sim 13 \mathrm{~cm} / \mathrm{kyr}$ across the $\mathrm{M}-\mathrm{B}$ boundary.

5. The "Pitagora ash" is within $0.5-1.0 \mathrm{~m}$ of the M-B boundary.

6. Detailed marine biostratigraphy including foraminifera and nannofossils.

7. Detailed pollen stratigraphy.

8. Section has good access.

The negative features are:

1. No isotope stratigraphy above MIS 18.4 , and short time span covered by the section.

2. A cyclothem boundary close to the Matuyama-Brunhes boundary.

3. An unexplained stratigraphically low position of the Matuyama-Brunhes boundary, before the MIS 19 peak.

4. Boundary layer ("Pitagora ash") not amenable to radiometric dating or extrabasinal correlation, and represents abrupt deposition.

5. Potential problems with preservation due to regolith creep.

\subsection{Chiba section (Chiba Prefecture, central Japan)}

The Chiba composite section is exposed along deeply incised river valleys on the Boso peninsula just south of the city of Chiba in central Japan. Here the Kazusa Group, which 
is Early to Middle Pleistocene (2.4-0.5 Ma) in age, is $\sim 3 \mathrm{~km}$ thick and continuously deposited, and mostly consists of marine sands and silts (Fig. 10). It is subdivided into 14 formations that are intercalated with around 50 tephra layers of which at least 18 are widespread. The Kazusa Formation is constrained by foraminiferal, calcareous nannofossil, and diatom biostratigraphy, and by benthic and foraminiferal oxygen isotope stratigraphy from MIS 34 to the MIS 16/15 transition. Magnetostratigraphy is recorded throughout, including the top of the Olduvai Subchron, the Jaramillo Subchron, and the Matuyama-Brunhes Chron boundary. A large literature exists on the Kazusa Group but is published mostly in Japanese and therefore not readily accessible. Kazaoka et al. (this volume) have addressed this limitation by synthesizing the geology of the Kazusa Group, including the Kokumoto Formation which spans the Early-Middle Pleistocene boundary.

The Kokumoto Formation varies from 350 to $400 \mathrm{~m}$ in thickness and was deposited on the slope and shelf edge. It contains the Matuyama-Brunhes Chron boundary, which has recently been studied in detail for magnetostratigraphy, marine isotope stratigraphy, and tephra analysis. The Matuyama-Brunhes boundary is located above the initial MIS 19 peak, and a distinctive tephra later, the Byakubi-E, which occurs $\sim 0.8 \mathrm{~m}$ below the midpoint of the boundary, has a U-Pb zircon age of $772.7 \pm 7.2 \mathrm{ka}$. Based on a sedimentation rate of $32.0 \pm 9.3 \mathrm{~cm} / \mathrm{ky}$ for this part of the section, the Matuyama-Brunhes boundary is estimated to have an age of $770.2 \pm 7.3 \mathrm{ka}$ (Suganuma et al., 2015), which is in agreement with most published high-sedimentation rate records (Head and Gibbard, submitted). The Matuyama-Brunhes directional transition has a duration of $2.8 \mathrm{kyr}$ (not $3.1 \mathrm{ka}$ as stated in Suganuma et al., 2015), which is within the range of reported durations. The primary magnetization carrier is magnetite (titanomagnetite). Takeshita et al. (2015) have shown that the Byakubi-E tephra can be traced widely across central Japan and is derived from the Older Ontake volcano 250 $\mathrm{km}$ to the west (Takeshita et al. (2015). It serves as a potential marker for the GSSP, and a useful guide for the Matuyama-Brunhes boundary particularly between the Tabuchi (proposed location of GSSP), Yanagawa, and Kogusabata sections that comprise the Chiba composite section (Suganuma et al., 2015 supplementary data).

In summary, the positive features of the Kazusa Group / Chiba composite section are:

1. Kazusa Group is $\sim 3 \mathrm{~km}$ thick, $2.4-0.5 \mathrm{Ma}$.

2. Marine oxygen isotopes (benthic and planktonic) recorded from MIS 34 to MIS $16 / 15$.

3. Detailed marine biostratigraphy including foraminifera and nannofossils.

4. Extensive published record of the composite section.

5. High sedimentation rates of $\sim 32.0 \mathrm{~cm} / \mathrm{ky}$ near the boundary.

6. Around 50 tephra layers present in the Kazusa Group, of which at least 18 are widespread.

7. Matuyama-Brunhes boundary recognized, and transition documented in detail.

8. The Byakubi-E tephra has a U-Pb zircon age of $772.7 \pm 7.2 \mathrm{ka}$ and occurs $\sim 0.8 \mathrm{~m}$ below the midpoint of the Matuyama-Brunhes boundary.

9. The Byakubi-E tephra can be traced across central Japan.

10. The section has excellent access and preservation, and is only $80 \mathrm{~km}$ from Tokyo.

The negative features are: 
1. Most of the older primary literature is in Japanese.

2. There is no detailed pollen record across the boundary interval.

3. Not able to serve as the unit stratotype for the Calabrian Stage, but the Kazusa Group does extend below base of Calabrian.

\section{The character of the Matuyama-Brunhes paleomagnetic transition}

The literature on the Matuyama-Brunhes boundary has been reviewed by Head and Gibbard (submitted) who show that most high-quality records estimate the boundary at around $772-773 \mathrm{ka}$, rather than the often cited age of 780-781 ka. These ages are mostly based on astronomically-tuned deep ocean records that place the Matuyama-Brunhes boundary in the middle to upper part of MIS 19 (above the initial MIS 19c peak), with a typical directional polarity duration of 2.9-7.0 kyr for the North Atlantic (Head and Gibbard, submitted). Most records show a relatively smooth directional transition, although a well documented "precursor" event precedes the boundary by $\sim 18 \mathrm{kyr}$ (Suganuma et al., 2015).

Not all records, however, are consistent with the above observations (Head and Gibbard, submitted). For example, the Matuyama-Brunhes boundary in the Valle di Manche section in southern Italy occurs before the peak of MIS 19c (see above). The directional polarity change in the lacustrine deposits of Sulmona in central Italy (Fig. 1) has an estimated duration of less than 100 years (Sagnotti et al., 2014).

Hyodo and Kitaba (this volume) have examined the MIS 19 and the timing of the Matuyama-Brunhes boundary from a long marine core taken from Osaka Bay in Japan. This record is unusual in that there are several paleomagnetic reversals through MIS 19c, and the peak in temperature, as determined from the rise in pollen of temperate trees (Quercus), occurs in the latter half of MIS 19c, representing a delay of 4000 years between the peak in sea level and the climatic thermal maximum. Hyodo and Kitaba attribute this delay to cooling caused by a weak magnetic field intensity, whereby an increased flux of cosmic radiation causes an enhanced cloud cover (see also Kitaba et al., 2013). These and other anomalies clearly require further investigation.

\section{The Middle-Upper Pleistocene Subseries boundary (0.7 Ma)}

It was during the $2^{\text {nd }}$ INQUA Congress in Leningrad in 1932 that a decision was made to define the base of the Upper Pleistocene at the base of the last interglacial (Eemian Stage in Europe). The 12th INQUA Congress in Ottawa in 1987 approved a proposal of the INQUA Working Group on Major Subdivision of the Pleistocene to use the base of MIS 5 to define the boundary (Anonymous, 1988; Richmond, 1989).

This presupposed a synchronicity between the base of MIS 5 and the base of the last interglacial, as implied by the general equivalence between MIS 5e, the lowest substage of MIS 5, and the Eemian Stage (Shackleton, 1977). However, a detailed palynological study of a marine core off Portugal (Sánchez-Goñi et al., 1999) later showed that the base of the Eemian pollen stage is about $6 \mathrm{kyr}$ younger than the base of 
MIS 5 and about 2 kyr younger than the plateau of lightest isotopic values for MIS $5 \mathrm{e}$ (Shackleton et al., 2003).

\subsection{Eemian (Amsterdam Terminal) proposal}

Consequently, Gibbard (2003) and Litt and Gibbard (2008) proposed that the Upper Pleistocene GSSP should be placed in a core from the Amsterdam Terminal, Netherlands - which is both the parastratotype and unit-stratotype for the Eemian Stage (van Leeuwen et al., 2000) - as this would respect the original definition of the boundary. This borehole had been drilled specifically by the Rijks Geologische Dienst (The Netherlands Geological Survey) in 1997 to document the Eemian as fully as possible (van Kolfschoten and Gibbard, 2000). The borehole was sited in the Amsterdam glacial basin, revealing a succession of Late Saalian lake and finally shallow pool deposits passing into Eemian freshwater and then brackish and shallow marine sediments (van Leeuwen et al., 2000). The proposed GSSP in this core was placed at the steep rise in tree pollen, especially that of Betula, that marks a synchronous response to climatic amelioration and characterizes the beginning of the Eemian across Europe (Pillans and Gibbard, 2012). Stratigraphically, the proposed GSSP was placed at $63.50 \mathrm{~m}$ depth at the base of a laminated greyish green diatomite underlain by a thin sand layer. The sand layer was interpreted to have been redeposited following erosion of coarse material from the nearby margins of what by now was a shallow pool (van Leeuwen et al., 2000). This ceased when denser vegetation cover associated with an ameliorating climate stabilized the margins (Litt et al., 2008). The deposition of a laminated greyish green diatomite above the thin sand layer marks the beginning of the Eemian, diatom assemblages reflecting a return to a deeper lake proper in the earliest Eemian (van Leeuwen et al., 2000), although there is no evidence of emergence at the boundary.

The proposal by Litt et al. (2008), representing the SQS Working Group on the Middle/Upper Pleistocene Boundary, received a $100 \%$ vote in favour by the SQS (18 voting, two not responding) and a $71 \%$ vote in favour by the ICS Full Commission (10 in favour, 4 against) (Ogg and Bown, 2008). The proposal was submitted by ICS to the IUGS Secretariat on 26 August, 2008 for ratification (Ogg and Bown, 2008). This request was denied by the IUGS EC on 22 September, 2008 (Riccardi, 2008) for various reasons, among which the observation that the proposed GSSP did not respond to the required "absence of vertical facies changes at or near the boundary" (Remane et al., 1996, p. 79), and the unclear potential of the proposed GSSP for precise long-range correlation, were particularly intractable. It may also be noted that a GSSP should represent a marine section (Salvador, 1994) whereas the proposed GSSP was placed in freshwater deposits, although it is pertinent of course that the Holocene GSSP, which is the next highest ratified GSSP, has been placed in an ice core (Walker et al., 2009). A revised version of the Litt et al. proposal was not submitted to the IUGS EC, and it was made clear that a revised version of the Litt et al. (2008) proposal would require resubmission to the SQS as a new proposal (Head et al., 2013). Hence, the search for an Upper Pleistocene GSSP was reopened.

\subsection{Tarentian (southern Italy) proposal}


The Tarentian is a regional (Italian) marine stage first proposed (as "Tarantian") by Cita and Castradori $(1994,1995)$ and Van Couvering (1995) for the interval spanning the MIS 6/5 transition to the base of the Holocene (Cita, 2008), and hence the Upper Pleistocene Subseries. It is a substitute for the Tyrrhenian stage, which is conceptually different (Cita, 2008). The Tarentian, from Tarentum the ancient Roman name for the type locality of Taranto, Apulia, southern Italy, has not yet been formally defined even for local application, and a reference section has not yet been designated. The Tarentian is hence a nomen nudum (Negri et al. this volume). The Tarentian is well exposed along the Fronte composite section in the vicinity of Taranto.

The paper by Negri et al. (this volume) follows Antonioli et al. (2008) in proposing the Tarentian deposits from the Fronte composite section as a potential GSSP for the Upper Pleistocene (Figs. 1, 11, 12). The Fronte section has been described in detail by Amorosi et al. (2014). The base consists of Middle Pleistocene Blue Clay, the upper part of which is assignable to MIS 13 (about $0.5 \mathrm{Ma}$ ). It is unconformably overlain by a thin fine-sandy bioclastic mud (unit 1), a highly fossiliferous shallow-marine grey mud (unit 2), a cemented, fossiliferous calcarenite regionally called panchina that is characterized by a warm-water "Senegalese" fauna mostly represented by molluscs (unit 3), a thick reddish to greenish open-shelf mud (unit 4), and a second fossiliferous calcarenite (unit 5) at the top. Units 1-5 span most of MIS 5e. The Garitta section is an adjacent exposure described by Negri et al. (this volume). It is just $20-30 \mathrm{~m}$ east of the section already detailed by Amorosi et al. (2014), but contains a thicker unit 4 (6.25 m vs. $4.5 \mathrm{~m}$ in Amorosi et al., 2014) that is shown from foraminiferal, dinocyst, and benthic $\delta^{18} \mathrm{O}$ studies to represent the MIS 5e peak/plateau. From a sequence stratigraphic perspective, the base of unit 1 represents a sequence boundary, units 1,2, 3 and the base of unit 4 represent a transgressive systems tract, the lower part of unit 4 (but excluding its lowermost part) represents the maximum flooding zone, and the upper part of unit 4 and unit 5 represent a highstand systems tract (Amorosi et al., 2014; Negri et al., this volume). No erosional surface was recognized at the top of unit 3. From a promising pilot study, Negri et al. show that unit 4 could yield a detailed paleomagnetic record including the Blake excursion at $123 \pm 3 \mathrm{ka}$ (see below) that would aid in marine and terrestrial global correlation of this potential global stratotype section. These authors suggest that the GSSP could be placed at the base of the maximum flooding zone, which is recognized $\sim 70 \mathrm{~cm}$ above the base of unit 4 , and $\sim 3.7 \mathrm{~m}$ above the base of the Late Pleistocene deposits. It is identified by an increase in the planktonic/benthic foraminiferal ratio, and a shift in the benthic foraminiferal assemblage composition. Negri et al. (this volume) interpret this to represent the second of two global sea-level rises documented for the last interglacial by Hearty et al. (2007, fig. 10, sl\#4) which these authors dated to 124-121 ka. However, the pattern of eustatic highstands for MIS 5e is uncertain (Ávila et al., 2015) and there are also uncertainties in the global $\delta^{18} \mathrm{O}$ signature. The suggested position of the GSSP occurs within the MIS 5e plateau. Unfortunately, the benthic $\delta^{18} \mathrm{O}$ record from the Fronte section is available only through unit 4, and shows little change. It is presumably entirely within the MIS 5e plateau, and does not capture the steep inflection characterizing the MIS 6-5 boundary.

\subsection{Northern European versus North American Last Interglacial records}


Otvos (this volume) assesses the northern European and North American Last Interglacial records, known respectively as the Eemian and Sangamonian regional stages, and discusses the problems arising from the confusion of these terms on the two continents. This confusion owes its origin to the fact that in North America, the Sangamonian Stage was originally identified from fossil soil in the mid-western states, whereas in northern and latterly southern Europe, the evidence is based principally on palynological subdivision. The result has been that the Sangamonian includes what in Europe is regarded as the Early Weichselian (glacial or cold) regional Substage sequences. That the latter includes two stadial and intervening interstadial events which are instead included within the Sangamonian in North America, means that the "Last Interglacial" on the two continents is of significantly different duration, causing unfortunate confusion. This article considers this problem from the perspective of the author who has studied coastal and littoral sequences along the southern coasts of the USA: it therefore brings a fresh approach to its resolution - the sea-level record being important in the absence of long pollen profiles from the North American continent.

The concept of the "Last Interglacial" has evolved considerably since its early establishment by Harting in the Netherlands in the late nineteenth century. Today, we are in the somewhat awkward situation whereby the original meaning, and therefore origin of the term "Eem(ian)", taken from the Eemnes area from where it was originally described, has been applied over large regions of the world, often without a clear understanding of the term's first use or definition. Running in parallel with the terrestrial (chrono-) stratigraphy is the marine isotope stratigraphy with the term Marine Isotope Stage (MIS) 5, the subdivisions of this stage being defined from the earliest works by Emiliani and Shackleton. In North America, the Sangamonian Stage was defined from the Sangamon Geosol but has been taken as the equivalent of the whole of MIS 5, whereas the Eemian is broadly equivalent only to MIS 5, Substage e. Attempts to correct the mismatch between the Eauropean and North American sequences by proposing an Eo-Wisconsinan Substage have not found favour. As Otvos rightly notes, the current usage is confused and inconsistent and certainly requires modification.

Central to the problem of the "Last Interglacial" sensu lato relates to the role of climate in the division and correlation of the events, which is addressed in this article. The desirability of separating time (i.e. chronostratigraphy) and climate (i.e. climatostratigraphy) is repeatedly stressed, as different events could then be placed more meaningfully on a time scale and rates of change, diachronism etc., could be properly assessed.

As Otvos states, there is evidence for glaciation during the Early Weichselian/Wisconsinan (or MIS 5, substages a-d) interval. Indeed, according to Hughes et al. (2013) "In numerous mountainous regions at high-, mid- and lowlatitudes across the world, glaciers reached their maximum extent before Marine Isotope Stage (MIS) 2, in MIS 5, 4 and 3. This is in contrast to most sectors of the Laurentide Ice Sheet, the Cordilleran Ice Sheet, the SE sector of the Fennoscandinavian Ice Sheet and the Alpine Ice Sheet in central Europe, which appear to have reached their maximum close to the global LGM in MIS 2." These points strongly support Otvos' thesis concerning the status of the Early Weichselian/Eo-Wisconsinan Substage. 
A single inshore-nearshore marine sediment and highstand interval is welldocumented in the region he studied in the southern USA, correlating with varied Eemian marine and paralic MIS 5e deposits encountered along northern and western European, Siberian, and additional shores. Apart from reliably dated Sangamonian South Florida coral reefs, identification and dating of Last Interglacial highstand deposits remain highly problematical in southeastern Atlantic shore terraces.

Problems of correlation for the Eemian interglacial event nonetheless remain.

They have arisen following detailed paleomagnetic studies by Sier et al. $(2011,2015)$ and Sier and Dekkers (2013) that have identified and compared the palaeomagnetic Blake Event at sites in northwestern, central, and southern Europe. This event can be applied as a chronostratigraphic marker for comparison of records from marine and terrestrial sequences, and between high and low latitudes, although published durations vary from $\sim 1$ kyr to more than 7 kyr. Sier et al. (2015) determined from an analysis of a research core at Rutten, about $75 \mathrm{~km}$ northeast of the Amsterdam terminal borehole, that the Blake Event has a minimum duration of 8000 years, but that there is also large geographic variability in the nature of this event. These authors concluded that it began $\sim 121.5 \mathrm{ka}$ and lasted to at least $113.5 \mathrm{ka}$. The results presented by Sier et al. (2015) suggest that the start of the Eemian interglacial climatic event was delayed by 5000 years in northwest Europe compared to that in southern Europe - a point originally proposed by Kukla et al (2002). The latter authors suggested that the Eemian Stage interglacial in western Europe lasted for 17,000 or even 23,000 yr based on comparison of the marine and southern European terrestrial biostratigraphies. However, this interpretation was catagorically rejected by Turner (2002) who demonstrated that the event lasted no more than 13,000 yr from sites north of the Alps and Pyrenees, based upon the counting of annually laminated lacustrine sediment sequences. The implication in any case is that the onset of the Eemian in northwestern Europe occurs later than the global sea-level highstand of MIS 5e. If correct, this could mitigate against adopting the Northwest European climatic template. It should be noted, however, that the Greenland ice sheet shows highest temperatures from $\sim 127 \mathrm{ka}$ (NEEM Community Members, 2013), suggesting that the Eemian in northwestern Europe did not start later than this. Clearly the resolution of this dilemma of the duration of this interglacial event and the timing of its associated marine transgression must await further clarification.

Notwithstanding this, Otvos concludes that adoption of the general European practice that asymmetrically splits MIS 5 into a short MIS 5e interglacial and a long early Wisconsinan Glacial (MIS 5d-a) interval is preferred in North America. Subdivisions in the normalized $\delta^{18} \mathrm{O}$ curve that serve as the chronological framework and the wealth of European pollen data support this approach. This potentially important problem has implications for understanding the climatic evolution and terminology in the Late Pleistocene Subseries.

\subsection{Future proposals}

Regarding any future proposal for the Upper Pleistocene GSSP, the following points obtain.

(1) The most unambiguously recognized part of the marine isotopic signature for MIS 5e is the steep inclination at the MIS 6-5 boundary (Termination II; 130 ka based 
orbital tuning in Lisiecki and Raymo, 2005), and the inception of the subsequent plateau. But isotope stratigraphy is not necessarily isochronous, and Lisiecki and Raymo (2009) documented Atlantic over Pacific leads of several thousands of years for the past six terminations.

(2) Modeling simulations incorporating ice core data from both Greenland and Antarctica show asynchronous peak temperatures, with North Atlantic high-latitude temperatures lagging southern hemisphere records by several thousand years (Capron et al., 2014).

(3) The Blake Event has an inherently unstable nature, and its expression varies with geography (Sier et al., 2015).

(4) The eustatic signature should be a globally synchronous proxy for ice volume, but is best observed in shallow and marginal marine settings that may have an incomplete stratigraphy.

(5) An Antarctic ice core should be considered for the GSSP. The abrupt methane rise seen in ice cores at Termination II is a distinctive global event (Capron et al., 2014) and could serve as the primary guide to the boundary. Methane rise is related closely to rising temperatures in the higher northern latitudes (methane lagged temperature rise by less than 30-70 years for the last glacial period in Greenland; Wolff and Spahni, 2008, Wolff, 2011), and the abrupt increase during Termination II is considered to reflect synchronous abrupt warming of the air above Greenland (Capron et al., 2014, p. 119). Termination II is well recorded in Antarctic ice cores, and has a gas orbital age of 132.4 $\mathrm{ka}$ at its midpoint, with a subsequent steep methane increase at $128.51 \pm 1.72 \mathrm{ka}$ in the EPICA Dome C core (Bazin et al., 2013) that leads the onset of the Eemian in southern Europe by about 2 kyr (e.g. Brauer et al., 2007).

(6) Speleothem records of the last interglacial from East Asia and elsewhere provide supporting detailed information on ice core records, including radiometric dating of Termination II that supports, within published errors, the gas orbital chronology of the Antarctic ice cores (Bazin et al., 2013; Genty et al., 2013).

\section{The GSSP for the Holocene Series/Epoch}

The Holocene (Greek: "wholly recent") refers to the percentage of extant organisms in the fossil record, and was defined by Gervais (1867-1869) "for the postdiluvial deposits approximately corresponding to the post-glacial period" (Bourdier, 1957, p. 101; Gibbard and van Kolfschoten, 2005). It compares approximately in extent to Lyell's (1839) "Recent" (see Walsh, 2008 for discussion), and to Forbes' (1846) "Postglacial". The International Geological Congress (IGC) in 1885 formally adopted the term Holocene in favour of "Recent", the latter term having no chronostratigraphic legitimacy.

An otherwise unremarkable interglacial, the Holocene has always been associated with the presence of humans. Charles Lyell defined his Recent as "[the time] elapsed since the earth has been tenanted by man" (Lyell, 1833, p. 52).

The base of the Holocene Series/Epoch was ratified by the IUGS EC on 8 May, 2008. It was the outcome a proposal submitted by a joint working group of the INQUA international focus group INTIMATE (Integration of ice-core, marine and terrestrial records) and the SQS. The GSSP is located at $1492.45 \mathrm{~m}$ in the NorthGRIP 2 (NGRIP2) 
Greenland ice core (Walker et al., 2009; Fig. 13), this being the first time an ice core had been used to define a GSSP. The GSSP reflects the first indications of climatic warming at the end of the Younger Dryas/Greenland Stadial 1 cold phase, and is marked by an abrupt decline in deuterium excess values as the primary guide. Other indicators include a short-term shift to heavier $\delta^{18} \mathrm{O}$ values (but longer-term shift to lighter $\delta^{18} \mathrm{O}$ ), shifts in other chemical proxies, a trend towards lower dust concentrations, and a sharp increase annual ice-layer thickness. The deuterium excess decline corresponds to an ocean surface temperature drop of $2-4^{\circ} \mathrm{C}$. This is interpreted to reflect a change in the source of precipitation from the mid-Atlantic Ocean during the glacial latest Pleistocene to colder higher latitudes in the early Holocene. It seems to have been caused by a rapid northward movement of the polar front, and hence represents a major and rapid climatic reorganization. Using multi-parameter annual layer counting, the base of the Holocene is dated to 11,700 calendar yr b2k (before AD 2000) with a maximum counting error of 99 yr $(2 \sigma)$ (Walker et al., 2009). As officially defined, the Holocene does not begin with the termination of the last cold stage (at 14, $500 \mathrm{cal}$. yr BP) but at the end of the Younger Dryas cooling event that interrupts post-glacial warming. The last cold stage termination can be difficult to detect precisely in marine records owing to the large quantities of cold meltwater being released, thereby complicating the warming signal. The ratified age of 11,700 calendar yr b2k is closer to the $10,000{ }^{14} \mathrm{C}$ yr BP age favoured during the $1960 \mathrm{~s}$ as a potential chronometric definition (i.e. a Global Standard Stratigraphic Age; GSSA) for the Holocene prior to the acceptance that a GSSP would be more desirable (Walker et al., 2009). Although defined in a Greenland ice core, the base of the Holocene can be identified precisely in Global Auxiliary Stratotypes designated in lake deposits from Germany, eastern Canada, Japan, and New Zealand, and a deep marine core from the Cariaco Basin, Venezuela (Walker et al., 2009).

The Holocene extends to the present day, and there is interest in predicting when it would end in the absence of anthropogenic forcing. Based on analogy with MIS 19, which has similar orbital characteristics, the end of the present interglacial would occur within the next 1500 years (Tzedakis et al., 2012), and may have already been prolonged by human-induced greenhouse gasses, including pre-industrial-age emissions (Giaccio et al., 2015).

\section{Subdivision of the Holocene Series/Epoch}

The concept of subseries for the Holocene Series has been discussed above (Section 5). A formal threefold subdivision of the Holocene was proposed by the INTIMATE/SQS joint working group in a discussion paper (Walker et al., 2012). This paper advocated the 8.2 ka cooling event as the primary guide for the Early-Middle Holocene boundary, with a suggested GSSP in the Greenland NGRIP1 ice core. The event is expressed in several Greenland ice cores by a pronounced brief ( 150 year) interval of heavier $\delta^{18} \mathrm{O}$ values, along with a decline in ice-core annual layer thickness and deuterium excess, a minimum in atmospheric methane, and subsequent $\mathrm{CO}_{2}$ increase. A distinct acidity peak likely representing an eruption from an Icelandic volcano was proposed as the marker horizon and has an age of 8,236 years b2k. The $8.2 \mathrm{ka}$ event is most conspicuous in mid- to high latitudes but is a near-global phenomenon and is detected in the tropics. It is recognized in marine (benthic and planktonic) as well as lacustrine, speleothem, and ice core records. 
In the South Atlantic and Southern Ocean, it may be expressed by a brief warming phase (Walker et al., 2012).

The discussion paper (Walker et al., 2012) also proposed the $4.2 \mathrm{ka}$ aridification event as the primary guide for the Middle-Late Pleistocene boundary. This event has been linked to cultural disturbance and collapse in North Africa, the Middle East and southern Asia (deMenocal, 2001; Walker et al., 2012). It is exemplified by a speleothem record (KM-A) with a five-year sample resolution from Mawmluh Cave in Cherrapunji, Meghalaya, north-east India. This record is based on $\delta^{18} \mathrm{O}$, the variability of which is used as a proxy for monsoon strength. It is constrained by U/Th dating, and spans 3600 to 12,500 years B.P. The heaviest $\delta^{18} \mathrm{O}$ values are between $4071 \pm 18$ and $3888 \pm 22$ years B.P. (midpoint 3.98 ka B.P.), representing an interval of 183 years, and represent a brief shift in Indian monsoon dynamics. This pronounced excursion is almost synchronous with the widely recognized low-latitude aridity event. Hence, as a novel departure from tradition, the stalagmite KM-A from the Mawmluh Cave (Berkelhammer et al., 2012) was suggested by Walker et al. (2012) as a potential GSSP for the base of the Upper Holocene subseries. The location of this potential GSSP is considered appropriate as the $4.2 \mathrm{ka}$ event is considered primarily a low-latitude phenomenon. Following a period of consulation and revision, it is expected that a formal proposal to approve the boundaries identified will be made to SQS and ultimately ICS shortly.

Kalnina et al. (this volume) have analyzed studies of peat stratigraphy and shifts in peat formation to assess the evolution of peatland in Latvia. Changing water levels in peatland affects rates of deposition and decomposition of the peat, as well as the vegetation, allowing the climate to be reconstructed in detail. Peatlands were established in the Early Holocene with cool, wet conditions characterizing the late Early Holocene. Warm and dry conditions in the Middle Holocene were replaced by wetter conditions in the Late Holocene, with a large number of bogs being established at this time.

Significantly, the changes in peatland stratigraphy broadly follow the tripartite proposal of Walker et al. (2012), although the Middle-Late Holocene boundary is transitional in nature.

The 4.2 ka event was not specifically recognized in the study of Kalnina et al. (this volume). In higher latitudes of the northern hemisphere and also in South America, it is often paradoxically expressed by cooler and/or wetter conditions (Roland, 2012, Roland et al., 2014), highlighting the complexity of processes responsible for this event. A detailed multiproxy analysis of the peatland record in Northern Ireland does not provide compelling evidence of a $4.2 \mathrm{ka}$ event, suggesting further spatial complexity for this event (Roland et al., 2014). Moreover, although the 4.2 event is recognized in marine deposits in lower latitudes owing to changes in the monsoon system, there is no evidence for extensive freshwater release into the North Atlantic or of significant northern hemisphere ice sheet growth (Walker et al., 2012). Accordingly, there is no clear global expression in the marine realm. Of course, in practice both the 8.2 and 4.2 boundaries can be determined using ${ }^{14} \mathrm{C}$ dating.

\section{Fine-scale division of the Quaternary}


The principal work of the SQS until now has rightly been the formal division of the Quaternary at the rank of stage or above, but these efforts have also highlighted the need to define chronostratigraphic terms of lower rank with greater precision. Many such terms in constant use in Quaternary research have either been inadequately defined or are applied in ways for which they were never originally intended. They include terms for short-term climate oscillations that have proliferated during the last two decades, in particular those used to identify the rapid changes now detected in ice-core and marine sediment sequences. Although such terms are of lower hierarchical status than the stages in which they occur, some have attainted a significant profile in stratigraphical and especially chronological communications (see Pillans and Gibbard, 2012).

\subsection{The "Last Glacial Maximum"}

The outstanding example of fine-scale division is the "Last Glacial Maximum", a term which, as Hughes and Gibbard (this volume) discuss in their contribution, has attained iconic status in Quaternary science. This term, equally familiar as the acronym LGM, is now ubiquitous in discussions of the last glaciation where it refers to the episode when global ice volume last reached its maximum, and the associated glacio-eustatic sea level stood at its lowest. It would be reasonable, therefore, to assume that this interval had been precisely defined, but in fact its boundaries are ill-defined and it has no formal stratigraphical basis. Despite a previous proposal to define it as a chronozone in the marine records on the basis of oxygen isotopes and sea levels, spanning the interval 2319 or 24-18 ka and centred on $21 \mathrm{ka}$ (e.g. Mix et al. 2001), the unit remains problematical. It is now questionable whether the criteria originally chosen by these authors still fall within their suggested chronozone time span, but the real issue concerns whether the boundaries can be time-correlated and so have any practical utility. In terrestrial records the LGM is poorly represented since many sequences show a diachronous response to global climate changes during the last glacial cycle. Indeed, the imprecision of the term has become increasingly apparent with the advent of numerical dating, which has demonstrated the asynchroneity of global glaciation (summarized in Hughes et al. 2013). The combined asynchrony and diachroneity of responses to global climate fluctuations in differing environmental settings inevitably provide potential pitfalls when the oscillations themselves are used as the basis for correlation.

As noted above, the LGM has been proposed as a chronozone based on marine isotope sequences. However, because the LGM (and isotope stage boundaries in general) does not have reliably isochronous boundaries as recognized within a marine sediment or ice-core sequence, it is difficult to use as a chronostratigraphic unit (Salvador, 1994; Ehlers et al., 2011). Moreover, the fact that glaciers around the world reached their maximum extents at different times during the last glacial cycle implies that the concept of a global LGM is of limited chronostratigraphical value when used to correlate glacial deposits and landforms (Hughes et al. 2013). This situation highlights the problems of using the marine isotopic record of global ice volume for correlating terrestrial sequences (Gibbard and West, 2000). This dilemma is not restricted to the glacial record, but also has relevance to any profile that is correlated with the marine isotope sequence based on assumptions of paleoenvironmental causation and counting backwards or forwards from apparent climatic marker events. Instead, the marine isotope record has the greatest value 
for terrestrial correlation simply as a broad foundation reference scale for global timeequivalence.

It is therefore more expedient to define a global LGM within event stratigraphy comparable to that already adopted for the Greenland ice-core sequence (see discussion in Hughes and Gibbard, this volume). These authors show that the global LGM can be defined as an event coeval with Greenland Stadial 3 (27.540-23.340 ka) in the NGRIP Greenland ice-core stratigraphy. This event spans several critical environmental global markers, including the global sea-level low-stand (Peltier and Fairbanks, 2006;

Thompson and Goldstein, 2006) and peaks in dust concentrations or dust flux recorded in the Greenland and Antarctic ice-core records (Ruth et al., 2007; Lambert et al., 2012), which coincide with the extension of the Laurentide Ice Sheet, and other major ice sheets, to their maximum.

As Hughes et al. (2013) noted, one of the major implications of the asynchroneity of maximum glacial extent apparent in the last glacial cycle is the possibility that this pattern might have been repeated during earlier glaciations, particularly during the Middle Pleistocene (Ehlers et al., 2011). If this occurred it could explain why some glaciations are represented in one region of the world, whilst elsewhere they seem to be unrepresented.

On a larger scale, Hughes and Gibbard (this volume) raise an important matter concerning the definition of climate events and their correlation on a global or at least extra-regional scale. Difficulties and potential pitfalls can arise when climatic changes are used to correlate strata or landforms based on fundamental assumptions of timeequivalence (i.e. climatostratigraphy), even when based on an event as significant as the LGM. The obvious lesson is that problems comparable to those outlined by Hughes and Gibbard are very likely to hold for most, if not all, potentially global events. The implication, therefore, is that in most cases, a climate signal cannot be assumed to have a simple coeval record across the world.

\subsection{Subdivision of regional stages}

A further matter concerns the general issue of the subdivision of the regional chronostratigraphic stages. The last glacial stage (Weichselian, Valdaian, Devensian, Wisconsinan and equivalents) has been divided into three, or previously four, substages (Early, Middle or Pleniglacial, Late Weichselian, etc., and Late-glacial), using geochronology (mainly $\left.{ }^{14} \mathrm{C}\right)$. Similar divisions were proposed for the North American Wisconsinan Stage (Chamberlin, 1895; Leighton, 1933). The most workable proposal to sub-divide the European Weichselian Stage is that by Mangerud et al. (1974). They proposed that the Early Weichselian/Middle Weichselian Substage boundary be placed at the Early Glacial/Pleniglacial boundary of van der Hammen et al. (1971) at 70 ka, and likewise that the Middle Weichselian/Late Weichselian Substage boundary be placed at a level corresponding to $\sim 13 \mathrm{ka}$, although the latter is now placed at $\sim 25 \mathrm{ka}{ }^{14} \mathrm{C}$ B.P. in order to correspond with the MIS 3/2 boundary (Thompson and Goldstein, 2006). They also proposed that the climatostratigraphic stadials and interstadials, formerly recognized within the Weichselian, should be redefined as chronozones in a formal chronostratigraphy. At the time, however, the terminology was deemed to be incomplete. In their system, the Late Weichselian Substage corresponded to the classical Late-glacial 
of northwestern Europe (beginning 13 ka), comprising the Oldest Dryas, Bølling, Older Dryas, Allerød, and Younger Dryas chronozones (Hartz and Milthers 1901; Iversen 1942, 1954, 1967, 1973; see Pillans and Gibbard, 2012). However, Mangerud et al. (1974) stated categorically that the term Late-glacial (and also Post-glacial) should not be used for formal stratigraphic units. These boundaries are based principally on dates and as such would be comparable to standard stratigraphic ages (i.e. regional standard stratigraphic ages or RSSAs) if they were formally defined. However, the definition of regional substages would preferably be from stratotype sections and points (RSSPs) for each boundary in common with the higher rank units.

The conventional three-fold division has not been proposed for the regional preWeichselian (and equivalent) glacial stages in Europe. However, with increasing knowledge of events, the potential for considering a comparable division of earlier stages can be feasible. By contrast, the biostratigraphic subdivision of European interglacial events is long established (e.g. Jessen and Milthers 1928; Turner and West 1968; Zagwijn, 1963).

The NW European Saalian/Wolstonian Stage (broadly equivalent to MIS 11b?-6) spans the period from the end of the Holsteinian / Hoxnian temperate (interglacial) Stage to the beginning of the Eemian/Ipswichian temperate (interglacial) Stage (Litt and Turner, 1993). It therefore represents an interval of approximately $260 \mathrm{ka}$, i.e. twice the duration of the Weichselian Stage. Division of the Saalian Stage would therefore seem obvious. The most efficient way to achieve this would be to divide it into early, middle and late substages, respectively, based broadly on the equivalent marine isotope stage divisions; MIS 11b-10, MIS 9-8 and MIS 7-6, respectively. Events within the substages could then be identified using the same approach as those within the Weichselian substages. The basal boundaries of these substages, in common with those mentioned above, would also require definition at stratotype reference localities.

While substage divisions are chronostratigraphic, i.e. they are based on "timerock" classification, it is important to restate that event stratigraphy has much to offer for communication of climate-driven sequences, such as those that characterize the Quaternary. The LGM exemplifies the value of adopting parallel classifications that serve subtly different functions. However, in this context, it is interesting that glacial maximum events (GMs) have not been formally recognized for earlier glaciations, although Margari et al. (2014) did note that for MIS 6 "eustatic sea level records and glacial geological evidence suggest that ice sheets expanded, with global ice-volume reaching its maximum extent towards the end of MIS 6", i.e. 140-136 ka (within MIS 6a; "PGM" - "Penultimate Glacial Maximum", sensu Stirling et al. 1998); or 149-140 ka (Railsback et al., 2014; unpublished). Previous glaciations also show GM peaks of similar duration, e.g. within MIS 12a ( 437-430 ka) and MIS 16a ( 640-625 ka), where marine isotope substage divisions follow Railsback et al. (2015).

Whether these events are as significant as the LGM remains to be seen, but the need for precision and consistency in the application and definition of stratigraphic terminology for small-scale divisions is unquestionably as important as for those of a larger scale. The definition of the units represents an important future task for the SQS.

\section{2. "Anthropocene"}


The discussion has focused to this point on the definition of existing chronostratigraphic units, but the recent proposal to establish an "Anthropocene" division in latest Quaternary time, has seen the term increasingly adopted by a range of workers, informally to identify the current interval of anthropogenically-driven global Earth system change. Zalasiewicz et al. (2015a [this volume]), which includes members of the SQS Anthropocene Working Group (AWG; strictly a "task group" according to ICS statutes), evaluate the need to determine whether the term "Anthropocene" could, or should, be defined as a formal series/epoch, based on the recognition of a suitable marker horizon or event. Following standard procedures, such a recognition would require the "Anthropocene" to have a global signature distinct from that of the Holocene or of previous interglacial events of the Pleistocene, and be marked by significant and potentially irreversible biotic (i.e., biostratigraphic), sedimentary and geochemical indicators. Notwithstanding the indisputable evidence in recent geological records of anthropogenic effects in natural environments, there are disagreements among workers whether the stratigraphic signature of these trends is sufficiently distinct and adequately dated at the global scale, for the proposal to be substantiated on stratigraphic grounds. Moreover there are strong variations of opinion on where in both time and place such a boundary could be located.

Bearing in mind these considerations, Zalasiewicz et al. recognize that humans began developing an increasing, but generally regional and highly diachronous, influence on the Earth System thousands of years ago. With the onset of the Industrial Revolution, humankind became a more pronounced geological factor, but they take the view that it was from the mid-20th century that the worldwide impact of the accelerating industrialisation and population growth became both global and near-synchronous.

\subsection{The onset of the "Anthropocene"}

The AWG members outline three potential options they are considering for a definition for the onset of the "Anthropocene": 1) an "early Anthropocene" some thousands of years ago (see Smith and Zender, 2013); 2) the beginning of the Industrial Revolution at 1800 CE (Common Era)(see Crutzen and Stroemer, 2000); and 3) the "Great Acceleration" of the mid-twentieth century (see Steffen et al., 2007). Of these, the last has the most pronounced and globally synchronous signal. In the light of these possibilities, Zalasiewicz et al. propose that the onset of the "Anthropocene" be marked not by a GSSP, as is established practice in the Phanerozoic part of the formally ratified global Geological Time Scale (GTS), but rather by a Global Standard Stratigraphic Age (GSSA), in other words a particular point in time, defined in this case in terms of the human calendar. They suggest that the boundary be recognized in geological (specifically chemostratigraphic) records by radiogenic fall-out from atmospheric nuclear explosions, and dated at the timing of the detonation of the first nuclear bomb at Alamogordo, New Mexico, USA, on $16^{\text {th }}$ July 1945 . While this may not be a perfect marker, it offers the potential to resolve the multiple lines of evidence on human-driven planetary change.

This event is favoured because standard stratigraphic practice requires definition of a significant, globally widespread and abrupt signature to identify the boundary event worldwide, and fallout from nuclear weapons testing seems most suitable (Waters et al., 2015). ${ }^{239} \mathrm{Pu}$ is the preferred isotope, being rare in nature, a significant component of fallout, with a long half-life ( $24 \mathrm{kyr})$, low solubility and high particle reactivity, making it 
a stable marker in sedimentary successions. A GSSP is therefore feasible to define the unit and would ideally be located about $30-60^{\circ}$ north of the Equator, where fallout was greatest and within anoxic or hypersaline environments associated with minimal bioturbation or sediment reworking (Waters et al., 2015). Waters et al. (2015) therefore prefer a GSSP to a GSSA as the means of definition, and for this purpose they point out that the initial nuclear weapons test at Alamogordo in 1945 lacks a clear radiogenic signature in the geological record. They note instead that the most pronounced rise in plutonium dispersal begins in 1952, resulting from a series of bomb tests that took place in the atmosphere, and that this would provide a more practical guide to the start of the "Anthropocene".

However, discussion of the "Anthropocene" definition question has moved forward rapidly. Of particular significance is a recent publication by Lewis and Maslin (2015), written apparently without knowledge of the Zalasiewicz et al. paper, that offers two different possible boundary dates, either 1610 or 1964 . The former, represented by what they term the "Orbis spike", is a sharp dip in atmospheric $\mathrm{CO}^{2}$ production, attributed to a massive decline in the human population of the Americas with the arrival of Europeans. More broadly, the "Orbis spike" is thought to reflect colonialism, global trade, and the burning of coal that initiated the increased human impact on the environment that Lewis and Maslin suggest characterizes the "Anthropocene". "Broadly, this highlights social concerns, particularly the unequal power relationships between different groups of people, economic growth, the impacts of globalized trade, and our current reliance on fossil fuels. The onward effects of the arrival of Europeans in the Americas also highlights a long-term and large-scale example of human actions unleashing processes that are difficult to predict or manage" (Lewis and Maslin, 2015, p. 177). Alternatively, they examine the ${ }^{239} \mathrm{Pu}$ radiogenic proposal of the AWG, preferring instead to locate the potential boundary later in 1964 near the peak of the atomic bomb testing era. In fact the peak of testing occurs in 1962-1963 just prior to the partial (atmospheric) test ban treaty of 1963. Interestingly, they suggest a potential GSSP in a tree ring sample from a pine (Pinus sylvestris) collected from Poland, to coincide with a pronounced spike in ${ }^{14} \mathrm{C}$ (another ubiquitous product of nuclear weapons testing but with a half-life of 5,730 years). They conclude that linking the "Anthropocene" to the onset of nuclear weapons testing "tells a story of an elite-driven technological development that threatens planet-wide destruction", but that a GSSP coinciding with the outcome of a test ban treaty will "highlight the ability of people to collectively successfully manage a major global threat to humans and the environment" (Lewis and Maslin, 2015, p. 178).

The Lewis and Maslin (2015) proposal has not met with universally positive acceptance, however. In a response to these authors, the AWG (Zalasiewicz et al., 2015b, 2015c) discuss both suggested GSSPs but point out that in order to fulfill the requirements of internationally recognized stratigraphical conventions, the proposed "Anthopocene" should reflect a unique stratigraphic unit characterized by anthropogenic signatures that are unambiguous, widespread and essentially permanent. They regard neither of the two dates proposed by Lewis and Maslin (2015) as being suitable to define the start of the event under these criteria. They do not consider the short-lived decline in 1610 of atmospheric $\mathrm{CO}_{2}$ to be a stratigraphically ideal marker for an epoch-scale boundary because it is within the range of natural variability for the Holocene, unlike the post-industrial signature, and the dip at 1610 neither matches the match the suggested 
regional anthropogenic trigger, nor matches global trends. Regarding the suggested date of 1964, the "Great Acceleration" in human activity had already started, and 1964 postdates the upturn seen in many physical and socio-economic trends and their stratigraphic signals that occurred around 1950 (Zalasiewicz et al., 2015b, c). Moreover, placing the boundary at the peak of the signal rather than at its inception does not follow normal stratigraphical practice (Zalasiewicz et al., 2015c). On these bases, the AWG have concluded that the Lewis and Maslin proposals bring useful perspectives and ideas, but do not resolve the issue of definition for the Anthropocene.

\subsection{The question of the status and rank (if any) for the "Anthropocene"}

Meanwhile discussions have continued on whether or not it is even possible to define a single horizon or start date, given that human activity began at markedly different times around the world. This was originally highlighted by Ruddiman (2003) and recently re-emphasized by the same author (Ruddiman et al. 2015), who questioned the wisdom of selecting 1945 as the start of the "Anthropocene" when this would exclude extensive agricultural and early-industrial modifications such as clear-cutting of forests in arable regions for agriculture, irrigating rice paddies, and ploughing and planting of prairie and steppe grasslands. A 1945 start would also exclude the important rise in $\mathrm{CO}_{2}$ and $\mathrm{CH}_{4}$ concentrations that stem from agricultural and industrial emissions. Ruddiman et al. (2015, p. 39) note that "forest cutting and grassland conversion are by far the two largest spatial transformations of Earth's surface in human history. From this viewpoint, the 'stratigraphically optimal' choice of 1945 as the start of the Anthropocene does not qualify as "environmentally optimal"'. Ruddiman et al. (2015) do conclude, however, that the term "Anthropocene" is clearly here to stay but that it might be used informally to avoid the confinement of a rigidly defined term while acknowledging humanity's environmental transformations of our planet.

This latter view is reinforced by other skeptical writers. For example, Walker et al. (2015) remark that "whilst there is a movement towards the recognition of a new period that acknowledges, and may indeed be characterised by, the influence of humans on much of the natural environment, the fact remains that we continue to live within the same climatic- and biologically-defined time interval for which the term 'Holocene' was proposed and formally ratified by the IUGS".

However, there is a potential danger that any one boundary definition would divide the research community, not serve its needs. "A 'late' boundary would reinforce problems that arise when change modeling is undertaken with too brief a time perspective" (J. Lewin, personal communication, 2015). Moreover, Finney (2014) has questioned the usefulness of defining an "Anthropocene" as a material unit for representation on geological maps. He also questions whether, and how, the useful designation "made ground" on maps and geological sections would be separated into "Anthropocene" and Holocene components. Walker et al. (2015) continue that "in the absence of a globally identifiable anthropogenic marker event that can be clearly recognized in a range of depositional contexts, that can be mapped in a conventional geological sense, and that can provide a consistent stratigraphic basis for detaching the 'Anthropocene' from the preceding Holocene, there is, in our view, no justification for formally defining the 'Anthropocene' as a new stratigraphic unit (of whatever status) 
within the established Geological Time Scale". In the absence of a distinctive and recognizable marker horizon, the geologist is left to "map a unit conceptually rather than conceptualizing a mappable stratigraphic unit" (Autin and Holbrook, 2012, p. 61).

Accepting that the "Anthropocene" is here to stay, and if it is to be regarded as a formal chronostratigraphic unit, then there is the question of its rank. The "Anthropocene", if defined as an epoch/series as is currently preferred by the Anthropocene Working Group, would truncate the Holocene Series and require stratigraphers to discriminate between the two. In routine mapping, this would be impractical, and the utility of the Holocene would then be diminished, with many surficial deposits of necessity being labeled "Holocene-Anthropocene". To avoid this inelegant terminology, it would make more sense to define the "Anthropocene" at the rank of stage or substage (if formalized at all), as this would maintain the Holocene in its useful, entire, traditional and historical contexts. It is not a trivial point that the Holocene has included modern deposits since its original inception in the late nineteenth century (Gervais, 1867-1869). The term "Anthropocene" as a stage (or substage) would need to carry the appropriate "-ian" ending.

Clearly there is a choice between two major, although very different interpretations of "Anthropocene" (Waters and Zalasiewicz, written communication 2015; Steffen, written communication 2015). Either it could be defined as a synchronously-bounded geological time unit describing a major change in the Earth system, reflected and recorded by changes in strata (whether human-made or not). As with all of geology, no stratigraphic signals are precisely synchronous, but some approach synchrony closely, and these are the ones most used in defining and locating a boundary. This is effectively the "Anthropocene" as originally proposed by Paul Crutzen (Crutzen and Stoermer, 2000) and then developed by Earth systems scientists. The stratigraphers' brief is to examine whether there is sufficient evidence in recent strata that reflects this change, and to recommend whether or not such a time unit might be formalized, and if so, how.

Alternatively it could be defined as a diachronously-bounded time unit, identified from those sediments that have been clearly reworked by or originate from human activity (Edgeworth et al. 2014). It follows that this "human imprint" is present earlier in some parts of the world than in others. It has been developed in the archaeological and related communities as a reinterpretation of the "Anthropocene" concept. It is a viable concept within the archaeological and related disciplines and is consistent with extant, culturally-based archaeological quasi-time unit divisions (Neolithic, Iron Age etc.) and in effect sums all of these. Conversely, it is not consistent with chronostratigraphic units nor viable as one.

Both concepts are valid within their respective spheres, and indeed, comparisons and correlations can be made between them. Both deserve names. But they cannot be hybridised in any effective way to make a single type of boundary, or share the same name "Anthropocene" if that name is to have any precise scientific meaning.

Discussions have so far centred on the northern hemisphere but a recent review by Lowe and Bostock (2015) offers an Australasian perspective. They conclude that of the potential boundaries suggested so far, only the Tambora eruption in Indonesia (AD 1815, and triggering brief global cooling), the "Great Acceleration" (AD 1950), and the nuclear weapons testing events (start AD 1945, peak 1964) are appropriate to Australasia. 
Whatever the ultimate decision, the AWG accepts that the process of boundary selection may encourage the historical and environmental communities to engage more effectively in the emerging interdisciplinary science basis of the "Anthropocene".

\section{Climate and Quaternary GSSPs}

The Quaternary represents a unique testing ground for chronostratigraphic concepts, including the selection of GSSPs. For example, no other geological period has an ice core record, and many quantitative dating methods do not extend beyond the Quaternary (Pillans and Gibbard, 2012). The range of GSSPs suggested, proposed, and ratified for the Quaternary illustrates the diversity of possibilities, and emphasizes the importance of Earth-system evolution, especially climate change, in formal chronostratigraphy.

The Gelasian and Calabrian Stage GSSPs are both orbitally constrained through marine isotope stratigraphy and sapropel stratigraphy, and both are positioned close to magnetostratigraphic boundaries. All three candidates for the Middle Pleistocene GSSP have marine isotope stratigraphy, two of the three (Chiba and Valle di Manche) have magnetostratigraphy, and two of three (Chiba and Montalbano Jonico) have an independent geochronology based on tephra dating (Section 6). All the above GSSP selections are based on outcropping marine deposits. They follow "conventional" concepts, in the sense of those generally followed in the Neogene, and they substantially meet ICS guidelines (Cowie, 1986; Cowie et al., 1986; Remane et al., 1996).

Nonetheless, the original intent for both Calabrian and Gelasian stages was to recognize pronounced cooling in and beyond the Mediterranean (Aguirre and Pasini, 1985; Rio et al., 1998), and the Middle Pleistocene GSSP will acknowledge a major shift in Earth's climate system (Head and Gibbard, submitted).

The Upper Pleistocene GSSP has been proposed within a non-marine interval in drilled core from the Amsterdam terminal borehole in the Netherlands (accepted by ICS but not ratified by IUGS; Section 8). A conventional onshore marine section, the Fronte Section in Taranto, Italy, has also been suggested (Negri et al., this volume). We suggest (Section 8) that an Antarctic ice core also be considered for the GSSP. The primary guide for the GSSP is the base of the last interglacial (base of MIS 5e), which is the warmest pre-Holocene interglacial since the Pliocene, and orbitally-constrained stratigraphy therefore is crucial.

The Holocene GSSP has been defined in the NGRIP Greenland ice core, using geochemical signals of warming after the Younger Dryas cold event as the primary guide for the GSSP. The precisely defined GSSP (Walker et al., 2009) can also be recognized globally by ${ }^{14} \mathrm{C}$ dating. Varved lake deposits in Sweden had been discussed previously for the Holocene GSSP (Walker et al., 2009). Suggestions for the Middle and Late Holocene subseries GSSPs are a Greenland ice core and an Indian stalagmite, repectively (Walker et al., 2012).

Whether the "Anthropocene" should be treated as a formal chronostratigraphic unit is currently under discussion, but both a GSSA (Zalasiewicz et al., this volume) and a GSSP (Waters et al., 2015) based on atomic weapons testing have been suggested. Lewis and Maslin (2015) suggested a tree ring sample from Poland as a GSSP for the 
"Anthropocene", as it could mark a pronounced spike in ${ }^{14} \mathrm{C}$ which is a ubiquitous product of nuclear weapons.

Creative approaches to GSSPs, especially for the later Quaternary, have been driven by the increasing demand for precise chronology, which is itself needed to understand millennial- or even centennial-scale leads and lags in the Quaternary climate system. This demand forces a departure from orthodox pre-Quaternary approaches. Nonetheless, GSSPs, regardless of the primary guides they represent, must be characterized by an array of markers to facilitiate global recognition in diverse sedimentary settings. Ultimately, the physical GSSP in the sedimentary record (the "golden spike") is the true global standard for chronostratigraphy, not the marker it is putatively represents.

\section{Summary and Conclusions}

The Quaternary, one of the earliest terms to enter the chronostratigraphic lexicon, was one of the last systems/periods to be satisfactorily defined, in 2009. Historically, it has been defined on climatic and biostratigraphic grounds, but its early connection with ice ages from the mid-nineteenth century onwards led to the misconception that it was not a legitimate chronostratigraphic unit and ultimately to its disappearance from the Geological Time Scale in 2004. Five years of fraught and often acrimonious interaction between INQUA/SQS and ICS/SNS ensued. Only with the appointment of a new ICS Executive in 2008, and the subsequent adherence to due process, was the situation resolved.

It is ironic that the chief objection to treating the Quaternary as a chronostratigraphic unit was based on its conceptual link to climatic deterioration, when both the Pleistocene (King and Oakley, 1949) and the Gelasian (Rio et al. 1998) were driven by the same concept. Assertions that the Neogene extends to the present day (Berggren, 1998) are based on an unjustified certainty about the original definition, and on the impractical assumption that original definition supercedes later use and custom (Walsh, 2006, 2008). As noted by Walsh (2008), objections to the Quaternary as a chronostratigraphic unit also arise from an outdated view that marine biochronology should hold a monopoly in defining Phanerozoic standard global geochronologic boundaries (Berggren, 1998, p. 125; Van Couvering, 2006, p. 310). With these prejudices removed, and with the strong support of INQUA, the Quaternary was ratified as a system/period with its base defined by the Gelasian GSSP at 2.6 Ma, in 2009.

The base of the Pleistocene was simultaneously lowered from the Vrica GSSP $(1.8 \mathrm{Ma})$ to that of the Gelasian $(2.6 \mathrm{Ma})$, not only to satisfy the hierarchical requirements of the timescale but also to rectify the mistaken claim that significant cooling in the Mediterranean began at 1.8 Ma. The Vrica GSSP was nonetheless used to define the Calabrian Stage, effectively the second stage of the Lower Pleistocene, in 2011. It is emphasized that while subseries are not currently represented in the International Geological Time Scale, they have long been used in Quaternary subdivision. Hence, it is agreed within SQS that the major divisions of the Pleistocene, Lower (Early), Middle and Upper (Late), should be subseries (subepochs). This quasi-formal tripartite subdivision 
has been in use since the 1930s. The definition of these subseries will be achieved in parallel with the definition of the "standard stages".

The Middle Pleistocene GSSP is a high priority for SQS and is near resolution, with three excellent candidate sections under consideration. These are the Montalbano Jonico and Valle di Manche sections in Basilicata and Calabria, respectively, in southern Italy, and the Chiba section in Japan. The Matuyama-Brunhes boundary, which serves as the primary guide for the Early-Middle Pleistocene boundary, is recorded only in the Valle di Manche and Chiba sections.

Since 1932, the base of the Upper Pleistocene has been defined by the base of the last interglacial, and this approximates the base of MIS 5e (Termination II, 130 ka). A proposal to define the Upper Pleistocene GSSP in the Amsterdam Terminal borehole in the Netherlands in 2008 was not approved by the IUGS EC, ultimately requiring that the search be reopened. The Fronte section in the vicinity of Taranto, Basilicata, southern Italy, serves as the potential reference for the Tarentian, a presently undefined regional (Italian) marine stage. It is also being considered as a potential GSSP for the Upper Pleistocene, although the interglacial marine deposits rest unconformably upon the $\sim 500$ ka Middle Pleistocene Blue Clay. Any of several Antarctic ice cores should be evaluated as an alternative GSSP, given that an abrupt methane rise seen in ice cores at Termination II is a distinctive global event. This could serve as the primary guide to the MiddleUpper Pleistocene boundary, with speleothem records providing detailed supporting information. Defining the base of the Upper Pleistocene, while obviously an important advance, will not solve all the problems of detailed interregional correlation within Last Interglacial deposits, especially where terrestrial deposits have recorded diachronous climatic events. In this regard, a greater understanding of the Blake Event ( 123 ka) could be of particular value, although it seems to be an unstable interval at the temporal resolution required.

The Holocene Series, ratified in 2008, was defined by a GSSP in the NorthGRIP 2 Greenland ice core. This was the first time an ice core had been used to define a GSSP. The base of the Holocene, at 11,700 calendar yr b2k, does not represent the termination of the last cold stage (at 14, 500 cal. yr BP) but at the end of the Younger Dryas cooling event that interrupts post-glacial warming. Counterintuitively, the primary guide, which is the deuterium excess decline, corresponds to an ocean surface temperature drop which is interpreted as a rapid northward movement of the polar front during global warming.

Attempts to subdivide the Holocene Series have a long history, but no formal or widely agreed scheme exists. A formal threefold subdivision of the Holocene has been proposed in a discussion paper by Walker et al. (2009), based on a Lower-Middle Holocene boundary at $8.2 \mathrm{ka}$ and a Middle-Upper Holocene boundary at $4.2 \mathrm{ka}$. The 8.2 ka event is a near-global cooling event with a suggested GSSP in the Greenland NGRIP1 ice core. The $4.2 \mathrm{ka}$ event is an aridification event primarily recognized in lower latitudes. This event may be difficult to recognize in higher latitude and the marine realm, although that may not be critical as this part of the time scale is well within the range of ${ }^{14} \mathrm{C}$ dating.

An important task of the SQS is to examine the fine-scale chronostratigraphic division of the Quaternary. The "Last Glacial Maximum" (LGM) exemplifies terminology that has assumed chronostratigraphic status with insufficient testing. Gibbard and Hughes (this volume) have shown that the LGM as a chronozone has 
questionable utility owing to the fact that glaciers around the world reached their maximum extents at different times during the last glacial cycle. Using event stratigraphy, the global LGM is more usefully defined as an event coeval with Greenland Stadial 3 (27.540-23.340 ka) in the NGRIP Greenland ice-core stratigraphy.

The "Anthropocene" is the latest division in Quaternary time. Although presently without rank or definition, it attempts to identify the current interval of anthropogenically-driven global Earth system change. The SQS Anthropocene Working Group has taken the view that the global and near-synchronous acceleration in industrialisation and population growth during the mid-20th century, the "Great Acceleration", is the most meaningful and practical definition for its onset. The formal rank of epoch/series is currently preferred. Zalasiewicz et al. (this volume) propose that the onset be marked by a Global Standard Stratigraphic Age (GSSA) dated at the timing of the detonation of the first nuclear bomb at Alamogordo, New Mexico, USA, on $16^{\text {th }}$ July 1945, although a GSSP using ${ }^{239} \mathrm{Pu}$ as the principal guide has also been recently suggested. Other definitions recently suggested include the "Orbis spike", a sharp dip in atmospheric $\mathrm{CO}^{2}$ production in 1610 linked to human population decline in the Americas, and the $1964{ }^{239} \mathrm{Pu}$ peak near the peak of the atomic bomb testing era. Then there is the question of rank. A formally defined "Anthropocene" at the rank of epoch/series would truncate the Holocene Series, and destabilize the geological time scale. A lower rank of stage, or substage, for the "Anthropocene" would circumvent this disturbance. Some authors have questioned whether it is even possible to meaningfully define a single horizon or start date, given the diachroneity of human activity around the world, and suggest an informal usage for the "Anthropocene".

Regardless of how the "Anthropocene" is finally resolved, it will have demonstrated, along with other boundaries discussed in this review, the enormous scope for creativity that the Quaternary offers in subdividing Earth's history.

\section{Acknowledgements}

We are grateful to Philip Hughes, Charles Turner, Bruce Railsback, and Mike Walker for helpful discussions. Jim Ogg kindly supplied information on IUGS matters, and Luca Capraro, John Clague, and Mike Walker provided photos of the Vrica Section, Monte San Nicola section, and Holocene GSSP, respectively. Luca Capraro, Neri Ciaranfi, Osamu Kazaoka, Hisao Kumai, Alessandra Negri, and many other colleagues, are warmly thanked for conducting field trips to examine potential GSSPs in Italy and Japan. MJH acknowledges support from a Discovery Grant of the Natural Sciences and Engineering Research Council of Canada.

\section{References}

Agassiz, L., 1840. Etudes sur les glaciers (private edition), Neuchâtel.

Agassiz, L., 1841. Glaciers and the evidences of their having once existed in Scotland, Ireland, and England. Proceedings of the Geological Society of London 3 (72), 327-332. 
Aguirre, E., Pasini, G., 1985. The Pliocene-Pleistocene boundary. Episodes 8, 116-120.

Aiello, G., Barra, D., Bonaduce, G., 2000. Systematics and biostratigraphy of the ostracoda of the Plio-Pleistocene Monte S. Nicola section (Gela, Sicily). Bollettino della Società Paleontologica Italiana 39, 83-112.

Aiello, G., Barra, D., Parisi, R., 2015. Lower-Middle Pleistocene ostracod assemblages from the Montalbano Jonico section (Basilicata, Southern Italy). Quaternary International (this volume).

Amorosi, A., Antonioli, F., Bertini, A., Marabini, S., Mastronuzzi, G., Montagna, P., Negri, A., Rossi, V., Scarponi, D., Taviani, M., Angeletti, L., Piva, A., Vai, G.B., 2014. The Middle-Upper Pleistocene Fronte Section (Taranto, Italy): An exceptionally preserved marine record of the Last Interglacial. Global and Planetary Change 119, 2338.

Anonymous, 1988. Biostratigraphy rejected for Pleistocene subdivisions. Episodes 11(3), 228.

Antonioli, F., Deino, A., Ferranti, L., Keller, J., Marabini, S., Mastronuzzi, G., Negri, A., Piva, A., Vai, G.B., Vigliotti, L. 2008. Lo Studio della sezione "Il Fronte" per la definizione del Piano Tarentiano (Puglia, Italy). Il Quaternario, Italian Journal of Quaternary Sciences 21(1A), 35-38.

Arduino, G., 1760. Sopra varie sue Osservazioni fatte in diverse parti del Territorio di Vicenza, ed altrove, appartenenti alla Teoria Terrestre, ed alla Mineralogia. Letter to Prof. Antonio Vallisnieri, dated $30^{\text {th }}$ March, 1759. Nuova Raccolta di Opuscoli Scientifici e Filologici (Venice), v. 6 (1760).

Arias, C., Azzaroli, A., Bigazzi, G., Bonadonna, F., 1980. Magnetostratigraphy and Pliocene-Pleistocene boundary in Italy. Quaternary Research 13, 65-74.

Aubry, M.-P., Berggren, W.A., Van Couvering, J., McGowran, B., Pillans, B., Hilgen, F., 2005. Quaternary: status, rank, definition, survival. Episodes 28, 118-120.

Aubry, M.-P., Berggren, W.A., Van Couvering, J., McGowran, B., Hilgen, F., Steininger, F., Lourens, L., 2009. The Neogene and Quaternary: chronostratigraphic compromise or non-overlapping magisteria? Stratigraphy 6, 1-16.

Autin, W.J., Holbrook, J., 2012. Is the Anthropocene an issue of stratigraphy or pop culture? GSA Today 22, 60-61.

Ávila, S.P., Melo, C., Silva, L., Ramalho, R.S., Quartau, R., Hipólito, A., Cordeiro, R., Rebelo, A.C., Madeira, P., Rovere, A., Hearty, P.J., Henriques, D., da Silva, C.M., de Frias Martins, A.M., Zazo, C., 2015. A review of the MIS 5e highstand deposits from 
Santa Maria Island (Azores, NE Atlantic): palaeobiodiversity, palaeoecology and palaeobiogeography. Quaternary Science Reviews 114 (2015) 126-148.

Bassett, M.G., 1985. Towards a "common language" in stratigraphy. Episodes 8(2), 8792.

Bazin, L., Landais, A., Lemieux-Dudon, B., Kele, H.T.M., Veres, D., Parrenin, F., Martinerie, P., Ritz, C., Capron, E., Lipenkov, V., Loutre, M.F., Raynaud, D., Vinther, B., Svensson, A., Rasmussen, S.O., Severi, M., Blunier, T., Leuenberger, M., Fischer, H., Masson-Delmotte, V., Chappellaz, J., Wolff, E., 2013. An optimized multi-proxy, multisite Antarctic ice and gas orbital chronology (AICC2012): 120-800 ka. Climate of the Past 9, 1715-1731.

Berggren, W.A., 1998. The Cenozoic Era: Lyellian (chrono)stratigraphy and nomenclatural reform at the millenium. In: Blundell, D.J., Scott, A.C. (Eds.), Lyell: the Past is the Key to the Present. Geological Society, Special Publication, 143. Geological Society, London, p. 111-132.

Berggren, W.A., Van Couvering, J.A., 1974. The Late Neogene. Paleogeography, Palaeoclimatology, Palaeoecology 16(1-2), 216 p.

Berggren, W.A., Van Couvering, J.A., 1982. Quaternary. In: Robison, R.A., and Teichert, C.D. (eds.), Treatise on Invertebrate Paleontology, Part A: Introduction, Fossilization (Taphonomy), Biogeography and Biostratigraphy. Geological Society of America, Boulder, A505-A543, University of Kansas Press, Laurence, KA.

Berggren, W.A., Kent, D.V., Swisher, C.C., III, Aubry, M.-P., 1995. A revised cenozoic geochronology and chronostratigraphy. In Berggren, W.A., Kent, D.V., Aubry, M.-P., Hardenbol, J., Eds., Geochronology time scales and global stratigraphic correlation, p. 129-212. Tulsa, OK: SEPM (Society of Economic Paleontologists and Mineralogists). Special Publication No. 54.

Berkelhammer, M.B., Sinha, A., Stott, L., Cheng, H., Pausata, F.S.R., Yoshimura, K., 2012. An abrupt shift in the Indian Monsoon 4000 years ago. Geophysical Research Letters 196: DOI: 10.1029/2012GM001207.

Bertini, A., Toti, F., Marino, M., Ciaranfi, N., 2015. Vegetation and climate across the Early-Middle Pleistocene transition at Montalbano Jonico, southern Italy. Quaternary International (this volume).

Bonaduce, G., Sprovieri, R., 1985. The appearance of Cytheropteron testudo Sars (Crustacea: Ostracoda) is a Pliocene event. Evidences from a Sicilian sequence (Italy). Bollettino della Societi Paleontologica Italiana 23(1), 131-136. 
Bourdier, F., 1957. Quaternaire. In: Pruvost, P. (Ed.), Lexique stratigraphique international. Vol. 1 Europe. Centre National de la Recherche Scientifique, Paris, pp. 99100.

Bowen, D.Q., 1988. Quaternary Geology: A Stratigraphic Framework for Multidisciplinary Work. Pergamon Press, Oxford, 237 pp.

Bowen, D.Q., Gibbard, P.L., 2007. The Quaternary is here to stay. Journal of Quaternary Science 22, 3-8.

Brauer, A., Allen, J.R.M., Mingram, J., Dulski, P., Wulf, S., Huntley, B., 2007. Evidence for last interglacial chronology and environmental change from Southern Europe. Proceedings of the National Academy of Sciences 104, 450-455.

Butzer, K.W., Isaac, G.L. (Editors), 1975. After the Australopithecines. Mouton, The Hague, 911 pp.

Capraro, L., Asioli, A., Backman, J., Bertoldi, R., Channell, J.E.T., Massari, F., Rio, D., 2005. Climatic patterns revealed by pollen and oxygen isotope records across the Brunhes-Matuyama boundary in the central Mediterranean (Southern Italy). In: Head, M.J., Gibbard, P.L. (Eds.), Geological Society of London, Special Publication, vol. 247, pp. 159-182.

Capraro, L., Macrì, P., Scarponi, D., Rio, D., 2015. The lower to Middle Pleistocene Valle di Manche section (Calabria, Southern Italy): State of the art and current advances. Quaternary International (this volume).

Capron, E., Govin, A., Stone, E.J., Masson-Delmotte, V., Mulitza, S., Otto-Bliesner, B., Rasmussen, T.L., Sime, L.C., Waelbroeck, C., Wolff, E.W., 2014. Temporal and spatial structure of multi-millennial temperature changes at high latitudes during the Last Interglacial. Quaternary Science Reviews 103, 116-133.

Castradori, D., Rio, D., Hilgen, F.J., Lourens, L.J., 1998. The global standard stratotypesection and point (GSSP) of the Piacenzian Stage (Middle Pliocene). Episodes 21, 8893.

Chamberlin, T.C., 1895. The classification of American glacial deposits. Journal of Geology 3, 270-277.

Ciaranfi, N., D'Alessandro, A., 2005. Overview of the Montalbano Jonico area and section: a proposal for a boundary stratotype for the lower-middle Pleistocene, Southern Italy Foredeep. Quaternary International 131, 5-10.

Ciaranfi, N., Lirer, F., Lirer, L., Lourens, L.J., Maiorano, P., Marino, M., Petrosino, P., Sprovieri, M., Stefanelli, S., Brilli, M., Girone, A., Joannin, S., Pelosi, N., Vallefuoco, M., 2010. Integrated stratigraphy and astronomical tuning of the Lower-Middle 
Pleistocene Montalbano Jonico land section (southern Italy). Quaternary International 210, 109-120.

Cita, M.B., 2008. Summary of the Italian marine stages of the Quaternary. Episodes 31(2), 251-254.

Cita, M.B., Castradori, D., 1994. Workshop on marine sections of Gulf of Taranto (Southern Italy) usable as potential stratotypes for the GSSP of the Lower, Middle and Upper Pleistocene. Il Quaternario 7, 677-692.

Cita, M.B., Castradori, D. 1995. Rapporto sul Workshop "Marine sections from the Gulf of Taranto (Southern Italy) usable as potential stratotypes for GSSP of the Lower, Middle and Upper Pleistocene”. Bollettino della Società Geologica Italiana 114, 319-336.

Cita, M.B., Capraro, L., Ciaranfi, N., Di Stefano, E., Marino, M., Rio, D., Sprovieri, R., Vai, G.B., 2006. Calabrian and Ionian: A proposal for the definition of Mediterranean stages for the Lower and Middle Pleistocene. Episodes 29(2), 107-114.

Cita, M.B., Gibbard, P.L., Head, M.J., and The Subcommission on Quaternary Stratigraphy, 2012. Formal ratification of the base Calabrian Stage GSSP (Pleistocene Series, Quaternary System). Episodes 35(3), 388-397.

Cowie, J.W., 1986. Guidelines for boundary stratotypes. Episodes 9(2), 78-82.

Cowie, J.W., Ziegler, W., Boucot, A.J., Bassett, M.G., Remane, J., 1986. Guidelines and statutes of the International Commission on Stratigraphy (ICS). Courier Forschungsinstitut Senckenberg 83, 1-14.

Cowie, J.W., Bassett, M.G. (compilers), 1989. 1989 global stratigraphic chart with geochronometric and magnetostratigraphic calibration. Episodes 12 (2), supplement, 1 sheet.

Crutzen, P.J., Stoermer, E.F., 2000. The Anthropocene. Global Change Newsletter 41, 17-18.

de Serres, M., 1830. De la simultaneité des terrains de sédiment supérieurs. In: La Géographie Physique de l'Encyclopédie Methodique, 5, 125 pp.

Deino, A.L., Kingston, J.D., Glen, J.M., Edgar, R.K., and Hill, A., 2006. Precessional forcing of lacustrine sedimentation in the late Cenozoic Chemeron Basin, Central Kenya Rift, and calibration of the Gauss/Matuyama boundary. Earth and Planetary Science Letters 247, 41-60.

deMenocal, P.B., 2001. Cultural responses to climate change during the Late Holocene. Science 292, 667-673. 
Desnoyers, J., 1829. Observations sur un ensemble de dépots marins plus récents que les terrains tertiaires du bassin de la Seine, et constituant une formation géologique distincte: précedées d'un apercu de la nonsimultanéité des bassins tertiaires. Annales scientifiques naturelles $16,171-214,402-419$.

Dowsett, H.J., 2007. The PRISM palaeoclimate reconstruction and Pliocene sea-surface temperature. In: Williams, M. et al. (eds.), Deep-Time Perspectives on Climate Change: Marrying the Signal from Computer Models and Biological Proxies. The Geological Society, London, 459-480.

Dreyfus, G.B., Raisbeck, G.M., Parrenin, F., Jouzel, J., Guyodo, Y., Nomade, S., Mazaud, A., 2008. An ice core perspective on the age of the Matuyama-Brunhes boundary. Earth and Planetary Science Letters 274, 151-156.

Edgeworth, M., Richter, D. deB., Waters, C., Haff, P., Neal, C., Price, S.J., 2014. Diachronous beginnings of the Anthropocene: The lower bounding surface of anthropogenic deposits. The Anthropocene Review 2, 33-58.

Ehlers, J., Gibbard, P.L., Hughes, P.D., (Eds.), 2011. Introduction. Quaternary Glaciations - Extent and Chronology: A Closer Look. Developments in Quaternary Science 15. Elsevier, Amsterdam, p. 1-14.

Farrand, W.R., 1990. Origins of Quaternary-Pleistocene-Holocene stratigraphic terminology. In: Laporte, L. F. (ed.), Establishment of Geologic Framework for Paleoanthropology. Geological Society of America Special Paper 242, p. 15-22.

Finney, S.C., 2010. Formal definition of the Quaternary System/Period and redefinition of the Pleistocene Series/Epoch. Episodes 33 (3), 159-163.

Finney, S.C., 2014. The 'Anthropocene' as a ratified unit in the ICS International Chronostratigraphic Chart: fundamental issues that must be addressed by the Task Group. In: Waters, C.N., Zalasiewicz, J., Williams, M., Ellis, M.A., Snelling, A. (eds.), A Stratigraphical Basis for the Anthropocene, Geological Society of London, Special Publications 395, 23-28.

Forbes, E., 1846. On the connexion between the distribution of the existing fauna and flora of the British Isles, and the geological changes which have affected their area, especially during the epoch of the Northern Drift. Memoirs of the Geological Survey of Great Britain 1, 336-432.

Genty, D., Verheyden, S., Wainer, K., 2013. Speleothem records over the last interglacial. PAGES news 21(1), 24-25.

Gerasimov, I.P., 1979. Anthropogene and its major problem. Boreas 8, 23-30. 
Gervais, P., 1867-1869. Zoologie et paleontology générales: Nouvelles recherches sur les animaux vertébrés et fossiles. Bertrand, Paris, 2.

Giaccio, B., Regattieri, E., Zanchetta, G., Nomade, S., Renne, P.R., Sprain, C.R., Drysdale, R.N., Tzedakis, P.C., Messina, P., Scardia, G., Sposato, A., Bassinot, F., 2015. Duration and dynamics of the best orbital analogue to the present interglacial. Geology, doi:10.1130/G36677.1

Gibbard, P.L., 2003. Definition of the Middle-Upper Pleistocene boundary. Global and Planetary Change 36, 201-208.

Gibbard, P.L., 2005. The status of the term 'Quaternary': Minutes of a special meeting of members of the joint ICS-INQUA task group held 24 March, 2005. Available online at: http://quaternary.stratigraphy.org/meetings/task.html

Gibbard, P., Head, M.J., 2009a. The definition of the Quaternary System/Era and the Pleistocene Series/Epoch. Quaternaire 20(2), 125-133.

Gibbard, P.L., Head, M.J., 2009b. IUGS ratification of the Quaternary System/Period and the Pleistocene Series/Epoch with a base at 2.58 Ma. Quaternaire 20(4), 411-412.

Gibbard, P.L., Head, M.J., 2010. The newly-ratified definition of the Quaternary System/Period and redefinition of the Pleistocene Series/Epoch, and comparison of proposals advanced prior to formal ratification. Episodes 33, 152-158.

Gibbard, P., van Kolfschoten, T., 2005. The Pleistocene and Holocene epochs, p. 441452. In: Gradstein, F.M., Ogg, J.G., and Smith, A.G. (eds.), A Geologic Time Scale 2004. Cambridge University Press, Cambridge, i-xix, 1-589 [Imprinted 2004].

Gibbard, P.L., West, R.G., 2000. Quaternary chronostratigraphy: the nomenclature of terrestrial sequences. Boreas 29, 329-336.

Gibbard, P.L., Head, M.J., Walker, M.J.C., The Subcommission on Quaternary Stratigraphy, 2010. Formal ratification of the Quaternary System/Period and the Pleistocene Series/Epoch with a base at 2.58 Ma. Journal of Quaternary Science 25(2), 96-102.

Gradstein, F.M., 2005. ICS Forum. Definition and status of the Quaternary. Stratigraphy 2(2), 191-192.

Gradstein, F., Ogg, J., 2002. Future directions in stratigraphy. Episodes 25(3), 203-208.

Gradstein, F.M., Ogg, J.G., 2004. Geologic Time Scale 2004 - why, how and where next! Lethaia 37, 175-181. 
Gradstein, F.M., Ogg, J.G., Smith, A.G., Bleeker, W., Lourens, L.J., 2004. A new geologic time scale with special reference to the Precambrian and Neogene. Episodes 27, 83-100, with accompanying chart.

Gradstein, F.M., Ogg, J.G., Smith, A.G. (eds.), 2005. A Geologic Time Scale 2004. Cambridge University Press, Cambridge, i-xix, 1-589 [Imprinted 2004, published March 2005].

Gradstein, F.M., Ogg, J.G., Schmitz, M.D., Ogg, G.M. (eds.), The Geologic Time Scale 2012. Two volumes. Elsevier, Oxford.

Harland, W.B., Cox, A.V., Llewellyn, P.G., Pickton, C.A.G., Smith, A.G., Walters, R., 1982. A geologic time scale. Cambridge University Press, Cambridge, i-xi, 1-131.

Harland, W.B., Armstrong, R.L., Cox, A.V., Craig, L.E., Smith, A.G., Smith, D.G., 1990. A geologic time scale 1989. Cambridge University Press, Cambridge, i-xvi, 1-263.

Hartz, N., Milthers, V., 1901. Det senglaciale Ler i Allerød Teglverksgrav. Meddelelser fra Dansk Geologisk Forening 8, 31-60.

Head, M., Zalasiewicz, J., Cohen, K., van Kolfschoten, T., Kalnina, L., Voelker, A., Negri, A., Lirer, F., Ciaranfi, N., Suganuma, Y., Kazaoka, O., Okumura, K., Gladenkov, Y., Morard, A., Miura, H., Agnini, C., Raffi, I., di Stefano, A., 2013. Minutes of the business meeting of the Subcommission on Quaternary Stratigraphy, International Commission on Stratigraphy, 5 July 2013, Gulbenkian Conference Centre, Lisbon, during the STRATI 2013 meeting. Available from the SQS website at: http://quaternary.stratigraphy.org/meetings/SQSMtg\%202013.pdf

Head, M.J., Gibbard, P.L., 2005. Early-Middle Pleistocene transitions: an overview and recommendation for the defining boundary. In: Head, M.J. and Gibbard, P.L. (eds.), Early-Middle Pleistocene transitions: the land-ocean evidence. Geological Society of London, Special Publication 247, p. 1-18.

Head, M.J., Gibbard, P.L., Salvador, A., 2008a. The Quaternary: its character and definition. Episodes 31(2), 234-238.

Head, M.J., Gibbard, P.L., and Salvador, A., 2008b. The Tertiary: a proposal for its formal definition. Episodes 31(2), 248-250.

Head, M.J., Pillans, B., Farquhar, S., 2008c. The Early-Middle Pleistocene Transition: characterization and proposed guide for the defining boundary. Episodes 31(2), 255-259.

Head, M.J., Gibbard, P.L., van Kolfschoten, T., 2013. The Quaternary System/Period: current status and future challenges. Ciências da Terra 18, 77-80. 
Head, M.J., Gibbard, P.L. Submitted. The Early-Middle Pleistocene transitions: linking terrestrial and marine realms. Quaternary International.

Hearty, P.J., Hollin, J.T., Neumann, A.C., O’Leary, M.J., McCulloch, M., 2007. Global sea-level fluctuations during the Last Interglaciation (MIS 5e). Quaternary Science Reviews 26, 2090-2112.

Hedberg, H.D. (ed.), 1976. International Stratigraphic Guide: A Guide to Stratigraphic Classification, Terminology, and Procedure. International Subcommission on Stratigraphic Classification of IUGS International Commission on Stratigraphy; and John Wiley and Sons, New York, London, xvii + 200 p.

Hennissen, J.A.I., Head, M.J., De Schepper, S., Groeneveld, J., 2014. Palynological evidence for a southward shift of the North Atlantic Current at 2.6 Ma during the intensification of late Cenozoic Northern Hemisphere glaciation. Paleoceanography 28, doi:10.1002/ 2013PA002543.

Hilgen, F., Aubry, M.-P., Mcgowran, B., Berggren, B.[W.A.], Lourens, L., Van Couvering, J., Steininger, F., 2008. Paleogene and Neogene Periods of the Cenozoic Era. A formal proposal and inclusive solution for the status of the Quaternary. Unpublished. Available from: http://quaternary.stratigraphy.org/Temporary\%20Items/

Hilgen, F.J., Lourens, L.J., Van Dam, J.A., 2012. The Neogene Period. In: Gradstein, F.M., Ogg, J.G., Schmitz, M.D., Ogg, G.M. (eds.), The Geologic Time Scale 2012, vol. 2. Elsevier, Oxford, p. 923-978.

Hopwood, A.T., 1935. Fossil elephants and Man. Proceedings of the Geologists' Association 46, 46-60.

Hörnes, M., 1851. Vorerinnerung [dated 1 July 1851]. In Die fossilen Mollusken des Tertiar-beckens von Wien. I. Band. Univalven, Hörnes, M., Partsch, P. (Authors). Abhandlungen der kaiserlich-königlichen geologischen Reichsanstalt 3 (Wien), 5-10.

Hörnes, M., 1853. Mittheilungen an Professor BRONN gerichtet. Neues Jahrbuch für Mineralogie, Geologie, Geognosie und Petrefakten-kunde 1853, 806-810.

Hughes, P.D., Gibbard, P.L., Ehlers, J., 2013. Timing of glaciation during the last glacial cycle: evaluating the meaning and significance of the 'Last Glacial Maximum' (LGM). Earth Science Reviews 125, 171-198.

Hughes, P.D., Gibbard, P.L., 2015. A stratigraphical basis for the Last Glacial Maximum (LGM). Quaternary International (this volume).

Hyodo, M., Kitaba, I., 2015. Timing of the MatuyamaeBrunhes geomagnetic reversal: Decoupled thermal maximum and sea-level highstand during Marine Isotope Stage 19. Quaternary International (this volume). 
INQUA Executive Committee, 2005. The Quaternary in the geologic time scale. Statement by INQUA Executive Committee, August 31, 2005. Unpublished, 1 p. Available from: http://quaternary.stratigraphy.org/meetings/task.html

INQUA Executive Committee, 2006. Letter to Dr. Felix Gradstein, Chairman, International Commission on Stratigraphy, dated March 24, 2006. Available from: http://quaternary.stratigraphy.org/meetings/task.html

INQUA Executive Committee, 2009. INQUA's position on the base of the Quaternary System/Period. Letter from John J. Clague and Brad Pillans on behalf of the INQUA Executive Committee to Prof. Stan Finney, Chair, ICS, dated 28 February, 2009.

ISSN (International Subcommission on Stratigraphic Classification), 2004. Newsletter 6 (Circular n. 107), December 2004, 41 pp. Available online from:

http://quaternary.stratigraphy.org/meetings/task.html

IUGS Executive Committee, 2006. Letter to Prof. Felix Gradstein, Chairman, International Commission on Stratigraphy, re. Quaternary in the Time-scale Charts. Dated August 25, 2006. Available from: http://quaternary.stratigraphy.org/meetings/task.html

IUGS Executive Committee, 2007a. Letter to ICS officers, re. IUGS International Commission on Stratigraphy, dated 5 February, 2007. Available from: http://quaternary.stratigraphy.org/meetings/task.html

IUGS Executive Committee, 2007b. Email from Peter T. Bobrowsky (Secretary General, IUGS) on behalf of IUGS EC to James Ogg (Secretary General, ICS), 28 May, 2007.

Iversen, J., 1942. En pollenanalytisk Tidsfæstelse af Ferskvandslagene ved Nørre Lyngby. Meddelelser fra Dansk Geologisk Forening 10, 130-151.

Iversen, J., 1954. The late-glacial flora of Denmark and its relation to climate and soil. Danmarks Geologisk Undersøgelse II. Rekke 80, 87-119.

Iversen, J., 1967. Naturens udvikling siden sidste istid. Danmarks Natur 1, 345-445.

Iversen, J., 1973. The development of Denmark's nature since the last glacial. Danmarks Geologisk Undersøgelse V:7c, 126 pp.

Jessen, K., Milthers, V., 1928. Stratigraphical and palaeontological studies of interglacial freshwater deposits in Jutland and Northwest Germany. Danmarks Geologisk Undersøgelse II, 48, $380 \mathrm{pp}$.

Kalnina, L., Stivrins, N., Kuske, E., Ozola, I., Pujate, A., Zeimule, S., Grudzinska, I., Ratniece, V., 2015. Peat stratigraphy and changes in peat formation during the Holocene 
in Latvia. Quaternary International (this volume).

Kazaoka, O., Suganuma, Y., Okada, M., Kameo, K., Head, M.J., Yoshida, T., Sugaya, M., Kameyama, S., Ogitsu, I., Nirei, H., Aida, N., Kumai, H., 2015. Stratigraphy of the Kazusa Group, Boso Peninsula: An expanded and highly-resolved marine sedimentary record from the Lower and Middle Pleistocene of Central Japan. Quaternary International (this volume).

King, W.B.R., Oakley, K.P., 1949a. Definition of the Pliocene-Pleistocene boundary. Nature 163, 186-187.

King, W.B.R., Oakley, K.P., 1949b. Report of the Temporary Commission on the PlioPleistocene Boundary, appointed 16th August 1948. In Butler, A.J., ed., IGC, 18th Session, Great Britain, 1948. Part I. General proceedings, 213-228. London: The Geological Society.

Kitaba, I., Hyodo, M., Katoh, S., Dettman, D.L., Sato, H., 2013. Mid-latitude cooling caused by geomagnetic field minimum during polarity reversal. Proceedings of the National Academy of Sciences of the United States of America 110, 1215-1220, doi.org/10.1073/pnas.1213389110.

Kukla, G., de Beaulieu, J.-L., Svobodova, H., Andrieu-Ponel, V., Thouveny, N., Stockhausen, H., 2002. Tentative correlation of pollen records of the Last Interglacial at Grande Pile and Ribains with Marine Isotope Stages. Quaternary Research 58, 32-35.

Lambert, F., Bigler, M., Steffensen, J.P., Hutterli, M., Fischer, H., 2012. Centennial mineral dust variability in high-resolution ice core data from Dome C, Antarctica. Climates of the Past 8, 609-623.

Leighton, M.M., 1933. The naming of the subdivisions of the Wisconsin glacial age. Science 77, 168.

Lewis, S.L., Maslin, M.A., 2015. Defining the Anthropocene. Nature, 519(7542), 171180.

Lisiecki, L.E., Raymo, M.E., 2005. A Pliocene-Pleistocene stack of 57 globally distributed benthic $\square^{18} \mathrm{O}$ records. Paleoceanography, 20, PA1003, doi:10.1029/2004PA001071.

Lisiecki, L.E., Raymo, M.E., 2009. Diachronous benthic $\delta^{18} \mathrm{O}$ responses during late Pleistocene terminations. Paleoceanography, 24, PA3210, doi:10.1029/2009PA001732.

Litt, T., Gibbard, P., 2008. A proposed Global Stratotype Section and Point (GSSP) for the base of the Upper (Late) Pleistocene Subseries (Quaternary System/Period). Episodes $31(2), 260-263$. 
Litt, T., Turner, C., 1993. Arbeitserbgenisse der Subkommission für Europäische Quartärstratigraphie: Die Saalesequenz in der Typusregion (Berichte der SEQS 10). Eiszeitalter und Gegenwart 43, 125-128.

Litt, T., Bettis III, E.A., Bosch, A., Dodonov, A., Gibbard, P., Jiaqi, L., Kershaw, P., von Koenigswald, W., McManus, J., Partridge, T., Turner, C. (Subcommission on Quaternary Stratigraphy (SQS) Working Group Middle/Upper Pleistocene Boundary), 2008. A proposal for the Global Stratotype Section and Point (GSSP) for the Middle/Upper (Late) Pleistocene Subseries boundary (Quaternary System/Period). Unpublished, 36 pp.

Lourens, L.J., 2008. On the Neogene-Quaternary debate. Episodes 31, 239-242.

Lourens, L., Hilgen, F., Shackleton, N.J., Laskar, J., Wilson, D., 2005. The Neogene Period. In: Gradstein, F.M., Ogg, J.G., Smith, A.G. (eds.), A Geologic Time Scale 2004. Cambridge University Press, Cambridge, p. 409-440 [Imprinted 2004].

Lowe, D.J., Bostock, H.C., 2015. The Anthropocene: an Australasian perspective and survey. New Zealand Soil News 67, 115-120.

Lyell C. 1833. Principles of Geology. Vol. III, 398 pp.+160 pp. appendices. [First London edition published by John Murray, reprinted as a facsimile in 1991 by the University of Chicago Press, with a new introduction and bibliography by Martin J.S. Rudwick].

Lyell, C., 1839. Nouveaux éléments de géologie. Pitois-Levrault et Cie, Paris, 648 pp.

Lyell, C., 1873. The geological evidences of the antiquity of man (4th edition). J. Murray, London, 572 pp.

Maiorano, P., Capotondi, L., Ciaranfi, N., Girone, A., Lirer, F., Marino, M., Pelosi, N., Petrosino, P., Piscitelli, A., 2010. Vrica-Crotone and Montalbano Jonico sections: a potential unit-stratotype of the Calabrian Stage. Episodes 33, 218-233.

Mangerud, J., Andersen, S.T., Berglund, B.E., Donner, J.J., 1974. Quaternary stratigraphy of Norden, a proposal for terminology and classification. Boreas 3, 109-12.

Margari, V., Skinner, L.C., Hodell, D.A., Martrat, B., Toucanne, S., Grimalt, J.O., Gibbard, P.L., Lunkka, J.P., Tzedakis, P.C., 2014. Land-ocean changes on orbital and millennial time scales and the penultimate glaciation. Geology 42, 183-186.

Marino, M., Bertini, A., Ciaranfi, N., Aiello, G., Barra, D., Gallicchio, S., Girone, A., La Perna, R., Lirer, F., Maiorano, P., Petrosino, P., Toti, F., 2015. Paleoenvironmental and climatostratigraphic insights for Marine Isotope Stage 19 (Pleistocene) at the Montalbano Jonico succession, South Italy. Quaternary International (this volume).

Massari, F., Capraro, L., Rio, D., 2007. Climatic modulation of timing of systems-tract 
development with respect to sea-level changes (middle Pleistocene of Crotone, Calabria, Southern Italy). Journal of Sedimentary Research 77, 461-468.

McGowran, B., Berggren, B.[W.A.], Hilgen, F., Steininger, F., Aubry, M.-P., Lourens, L., Van Couvering, J., 2009. Neogene and Quaternary coexisting in the geological time scale: The inclusive compromise. Earth-Science Reviews 96, 249-262.

Mix, A.C., Bard, E., Schneider, R., 2001. Environmental processes of the ice age: land, oceans, glaciers (EPILOG). Quaternary Science Reviews 20, 627-657.

Morlot, A., 1854/56. Notice sur le Quaternaire en Suisse. Bulletin de la Société vaudoise des sciences naturelles, 4 (32), 41-45.

Morlot, A., 1859. Sur le terrain Quartaire du Basin du Léman. Bulletin de la Société vaudoise des sciences naturelles 6 (44), 101-108.

NEEM Community Members, 2013. Eemian interglacial reconstructed from a Greenland folded ice core. Nature 493, 489-494.

Negri, A., Amorosi, A., Antonioli, F., Bertini, A., Florindo, F., Lurcock, P.C., Marabini, S., Mastronuzzi, G., Regattieri, E., Rossi, V., Scarponi, D., Taviani, M., Zanchetta, G., Vai, G.B., 2015. A potential global boundary stratotype section and point (GSSP) for the Tarentian Stage, Upper Pleistocene, from the Taranto area (Italy): Results and future perspectives. Quaternary International (this volume).

Nikiforova, K.V., Alekseev, M.N., 1997. International Geological Correlation Program, Project 41: "Neogene/Quaternary Boundary". In: Van Couvering, J.A. (ed.), The Pleistocene Boundary and the Beginning of the Quaternary, p. 3-12.

Ogg, J., 2004. Introduction to concepts and proposed standardization of the term "Quaternary". Episodes 27(2), 125-126.

Ogg, J., Bown, P., 2008. Request for IUGS ratification of the GSSP defining the base of the upper subdivision (subseries) of the Pleistocene Series. Unpublished letter to the IUGS Secretariat, with attachments. Twenty-seven pages. Dated 26 August, 2008.

Ogg, J.G., Pillans, B., 2008. Establishing Quaternary as a formal international Period/System. Episodes 31(2), 230-233.

Otvos, E.G., 2015. The Last Interglacial Stage: Definitions and marine highstand, North America and Eurasia. Quaternary International (this volume).

Pasini, G., Colanongo, M.L., 1997. The Pliocene-Pleistocene boundary-stratotype at Vrica, Italy. In: Van Couvering, J.A. (ed.), The Pleistocene Boundary and the Beginning of the Quaternary. Cambridge University Press, Cambridge U.K., p. 15-45. 
Peltier, W.R., Fairbanks, R.G., 2006. Global glacial ice volume and Last Glacial Maximum duration from an extended Barbados sea level record. Quaternary Science Reviews 26, 862-875.

Petrosino, P., Jicha, B.R., Mazzeo, F.C., Ciaranfi, N., Girone, A. Maiorano, P., Marino, M., 2015. The Montalbano Jonico marine succession: An archive for distal tephra layers at the Early-Middle Pleistocene boundary in southern Italy. Quaternary International (this volume).

Pillans, B., 2003. Subdividing the Pleistocene using the Matuyama-Brunhes boundary (MBB): an Australasian perspective. Quaternary Science Reviews 22, 1569-1577.

Pillans, B., 2004. Proposal to redefine the Quaternary. Episodes 27(2), 125-126.

Pillans, B., Naish, T., 2004. Defining the Quaternary. Quaternary Science Reviews 23, 2271-2282.

Pillans, B., Gibbard, P., 2012. The Quaternary Period. In: Gradstein, F.M., Ogg, J.G., Schmitz, M.D., Ogg, G.M. (eds.), The Geologic Time Scale 2012, vol. 2. Elsevier, Oxford, p. 979-1010.

Prat, S., 2007. The Quaternary boundary: 1.8 or 2.6 millions years old? Contributions of early Homo. Quaternaire 18, 99-107.

Railsback, L.B., Xiao, H., Liang, F., Akers, P.D., Brook, G.A., Dennis, W.M., Lanier, T.E., Tanf, M., Cheng, H., Edwards, R.L., 2014. A stalagmite record of abrupt climate change and possible westerlies-derived atmospheric precipitation during the Penultimate Glacial Maximum in northern China. Palaeogeography, Palaeoclimatology, Palaeoecology 393, 30-44.

Railsback, L.B., Gibbard, P.L., Head, M.J., Voarintsoa, N.R.G., Toucanne, S., 2015. An optimized scheme of lettered marine isotope substages for the last 1.0 million years, and the climatostratigraphic nature of isotope stages and substages. Quaternary Science Reviews 111, 94-106.

Railsback, L.B., Brook, G.A., Ellwood, B.B., Liang, F., Cheng, H., Edwards, R.L. Submitted. A record of wet glacial stages and dry interglacial stages over the last $560 \mathrm{kyr}$ from a standing massive stalagmite in Carlsbad Cavern, New Mexico, USA.

Palaeogeography, Palaeoclimatology, Palaeoecology (unpublished).

Reboul, H. 1833. Géologie de la période Quaternaire et introduction à l'histoire ancienne. Paris: F.G. Levrault, 222 pp.

Remane, J. (compiler), 2000. International Stratigraphic Chart. International Union of Geological Sciences, and UNESCO Division of Earth Sciences: Paris. 
Remane, J., and Michelsen, O., 1998. Report on the vote about the demand to lower the Plio-Pleistocene boundary (PPB). Unpublished report of the International Commission on Stratigraphy, dated 21 December 1998, 3 pp. [reproduced in Newsletter no. 6 of the International Subcommission on Stratigraphic Clasification, December 2004, pp. 5-7. Available from http://users.unimi.it/issc/webapp/uploads/6_ISSC_nl06.pdf]

Remane, J., Bassett, M.G., Cowie, J.W., Gohrbandt, K.H., Lane, H.R., Michelsen, O., and Wang, N., with the cooperation of members of ICS, 1996. Revised guidelines for the establishment of global chronostratigraphic standards by the International Commision on Stratigraphy (ICS). Episodes, 19, 77-81.

Rio, D., Sprovieri, R., Thunell, R., 1991. Pliocene-lower Pleistocene chronostratigraphy: A re-evaluation of Mediterranean type sections. Bulletin of the Geological Society of America 103, 1049-1058.

Rio, D., Sprovieri, R., Di Stefano, E., 1994, The Gelasian Stage: a proposal of a new chronostratigraphic unit of the Pliocene Series. Rivista Italiana di Paleontologia e Stratigrafia 100, 103-124.

Rio, D., Channell, J.E.T., Massari, F., Poli M.S., Sgavetti, M., D’Alessandro, A., Prosser, G., 1996. Reading Pleistocene eustasy in a tectonically active siliciclastic shelf setting (Crotone peninsula, southern Italy). Geology 24, 743-746.

Rio, D., Sprovieri, R., Castradori, D., Di Stefano, E., 1998. The Gelasian Stage (Upper Pliocene): A new unit of the global standard chronostratigraphic scale. Episodes 21, 8287.

Riccardi, A.C., 2008. Unpublished letter to Dr Stanley Finney, Chairman, International Commission on Stratigraphy. Two pages. Dated 22 September, 2008. [A.C. Riccardi was then President of the IUGS].

Richmond, G.M., 1996. The INQUA-approved provisional Lower-Middle Pleistocene boundary. In: Turner, C. (Ed.), The Early Middle Pleistocene in Europe. Balkema, Rotterdam, pp. 319-326.

Roberts, A.P., Florindo, F., Larrasoaña, J.C., O’Regan, M.A., and Xiang Zhao, 2010. Complex polarity pattern at the former Plio-Pleistocene global stratotype section at Vrica (Italy): Remagnetization by magnetic iron sulphides. Earth and Planetary Science Letters 292, 98-111.

Rocha, R., Pais, J., Kullberg, J.C., Castro, L., Caetano, P., Legoinha, P., 2013. STRATI 2013. First International Congress on Stratigraphy. On the cutting edge of stratigraphy. Ciências da Terra, special volume VII (program and abstracts), pp. i-xxviii, 1-211.

Roland, T.P., 2012. Was There a 4.2 Kyr Event in Great Britain and Ireland? Evidence from the Peatland Record. PhD thesis. University of Exeter. 
Roland, T.P., Caseldine, C.J., Charman, D.J., Turney, C.S.M., Amesbury, M.J., 2014. Was there a '4.2 ka event' in Great Britain and Ireland? Evidence from the peatland record. Quaternary Science Reviews 83, 11-27.

Ruddiman, W.F., 2003. The anthropogenic greenhouse era began thousands of years ago. Climatic Change 61, 261-293.

Ruddiman, W.F., Ellis, E.C., Kaplan, J.O., Fuller, D.Q., 2015. Defining the epoch we live in. Science 348(6230), 38-39.

Ruth, U., Bigler, M., Rothlisberger, R., Siggaard-Andersen, M.L., Kipfstuhl, S., GotoAzuma, K., Hansson, M.E., Johnsen, S.J., Lu, H.Y., Steffensen, J.P., 2007. Ice core evidence for a very tight link between North Atlantic and east Asian glacial climate. Geophysical Research Letters 34, L03706. doi:10.1029/2006GL027876.

Sagnotti, L., Cascella, A., Ciaranfi, N., Macrì, P., Maiorano, P., Marino, M., Taddeucci, J., 2010. Rock magnetism and palaeomagnetism of the Montalbano Jonico section (Italy): evidence for late diagenetic growth of greigite and implications for magnetostratigraphy. Geophysical Journal International 180, 1049-1066.

Sagnotti, L., Scardia, G., Giaccio, B., Liddicoat, J.C., Nomade, S., Renne, P.R., Sprain, C.J., 2014. Extremely rapid directional change during Matuyama-Brunhes geomagnetic polarity reversal. Geophysical Journal International 199, 1110-1124.

Sánchez-Goñi, M.F., Eynaud, F., Turon, J.L., Shackleton, N.J., 1999. High resolution palynological record off the Iberian margin: direct land-sea correlation for the last interglacial complex. Earth and Planetary Science Letters 171, 123-137.

Salvador, A. (ed.), 1994. International Stratigraphic Guide: A Guide to Stratigraphic Classification, Terminology, and Procedure, Second Edition. International Subcommission on Stratigraphic Classification of IUGS International Commission on Stratigraphy and The Geological Society of America, Boulder, Colorado, xix + 214 p.

Salvador, A., 2006a. The Tertiary and the Quaternary are here to stay. AAPG Bulletin 90, 21-30.

Salvador, A., 2006b. A stable Cenozoic geologic time scale is indispensable. Episodes $29,43-45$.

Scarponi, D., Huntley, J.W., Capraro, L., Raffi, S., 2014. Stratigraphic paleoecology of the S. Mauro Marchesato Section (Crotone Basin, Italy): a candidate GSSP of the Middle Pleistocene. Palaeogeography, Palaeoclimatology, Palaeoecology 402, 30-43.

Shackleton, N.J., 1977. The oxygen isotope stratigraphic record of the Late Pleistocene. Philosophical Transactions of the Royal Society of London, B 280, 169-182. 
Shackleton, N.J., Chapman, M., Sánchez-Goñi, M.F., Pailler, D., Lancelot, Y., 2002. The classic Marine Isotope Substage 5e. Quaternary Research 58, 14-16.

Shackleton, N.J., Sánchez-Goñi, M.F., Pailler, D., Lancelot, Y., 2003. Marine Isotope Substage 5e and the Eemian Interglacial. Global and Planetary Change 36, 151-155.

Shik, S.M., 2014. A Modern Approach to the Neopleistocene Stratigraphy and Paleogeography of Central European Russia. Stratigraphy and Geological Correlation 22 (2), 219-230.

Sier, M.J., Roebroeks, W., Bakels, C.C., Dekkers, M.J., Brühl, E., De Loecker, D., Gaudzinski-Windheuser, S., Hesse, N., Jagich, A., Kindler, L., Kuijper, W.J., Laurat, T., Mücher, H.J., Penkman, K.E.H., Richter, D., van Hinsbergen, D.J.J., 2011. Direct terrestrial-marine correlation demonstrates surprisingly late onset of the last interglacial in central Europe. Quaternary Research 75, 213-218. http://dx.doi.org/ 10.1016/j.yqres.2010.11.003.

Sier, M.J., Dekkers, M.J., 2013. Magnetic property analysis as palaeoenvironmental proxy: a case study of the Last Interglacial Middle Palaeolithic site at Neumark-Nord 2 (Germany). In: Gaudzinski-Windheuser, S., Roebroeks, W. (Eds.), Multidisciplinary Studies of the Middle Palaeolithic Record from Neumark-nord (Germany). LDASA, Halle, pp. 117e130.

Sier, M. J., Peeters, J., Dekkers, M. J., Parés, J. M., Chang, L., Busschers, F. S., Cohen, K.M., Wallinga, J., Bunnik, F.P.M., Roebroeks, W., 2015. The Blake Event recorded near the Eemian type locality - A diachronic onset of the Eemian in Europe. Quaternary Geochronology 28, 12-28.

Smith, B.D., Zeder, M.A., 2013. The onset of the Anthropocene. Anthropocene 4, 8-13.

Steffen, W., Crutzen, P.J., McNeill, J.R., 2007. The Anthropocene: are humans now overwhelming the great forces of Nature? Ambio 36, 614-621.

Stirling, C.H., Esat, T.M., Lambeck, K., McCulloch, M.T., 1998. Timing and duration of the Last Interglacial: evidence for a restricted interval of widespread coral reef growth. Earth and Planetary Science Letters 160, 745-762.

Suc, J.-P., Bertini, A., Leroy, S.A.G., Suballyova, D., 1997. Towards the lowering of the Pliocene/Pleistocene boundary to the Gauss-Matuyama reversal. Quaternary International 40, 37-42.

Suganuma, Y., Okada, M., Horie, K., Kaiden, H., Takehara, M., Senda, R., Kimura, J.-I., Kawamura, K., Haneda, Y., Kazaoka, O., Head, M.J., 2015. Age of Matuyama-Brunhes boundary constrained by U-Pb zircon dating of a widespread tephra. Geology, doi:10.1130/G36625.1 
Takeshita, Y., Matsushima, N., Teradaira, H., Uchiyama, T., Kumai, H., 2015. A marker tephra bed close to the Lower-Middle Pleistocene boundary: Distribution of the OntakeByakubi Tephra Bed in central Japan. Quaternary International, http://dx.doi.org/10.1016/j.quaint.2015.03.054

Thompson, W.G., Goldstein, S.L., 2006. A radiometric calibration of the SPECMAP timescale. Quaternary Science Reviews 25, 3207-3215.

Turner, C., 2002. Problems of the duration of the Eemian Interglacial in Europe north of the Alps. Quaternary Research 58, 45-48.

Turner, C., West, R.G., 1968. The subdivision and zonation of interglacial periods. Eiszeitalter und Gegenwart 19, 93-101.

Tzedakis, P. C., Channell, J. E. T., Hodell, D. A., Kleiven, H. F., Skinner, L. C., 2012. Determining the natural length of the current interglacial. Nature Geoscience 5, DOI: 10.1038/NGEO1358.

Vaccari, E., 2006. The "classification" of mountains in eighteenth century Italy and the lithostratigraphic theory of Giovanni Arduino (1714-1795). Geological Society of America Special Paper 411, 157-177.

van Kolfschoten, T., Gibbard, P.L., 2000, The Eemian - local sequences, global perspectives: introduction. Geologie en Mijnbouw/Netherlands Journal of Geosciences 79, 129-133.

Van Couvering, J.A., 1995. Setting Pleistocene marine stages. Geotimes 40, 10-11.

Van Couvering J.A., 2006. Editorial: No warming in the Quaternary. Stratigraphy 2, 310. [Imprinted 2005]

Van Couvering, J.A., ed., 1997. The Pleistocene Boundary and the Beginning of the Quaternary. Cambridge University Press, Cambridge U.K., 296 pp.

Van Couvering, J.A., Castradori, D., Cita, M.B., Hilgen, F.J., Rio, D., 2000. The base of the Zanclean Stage and of the Pliocene Series. Episodes 23, 179-187.

Van der Laan, E., Gaboardi, S., Hilgen, F.J., Lourens, L.J., 2005. Regional climate and glacial control on high-resolution oxygen isotope records from Ain el Beida (latest Miocene, NW Morocco): A cyclostratigraphic analysis in the depth and time domain. Paleoceanography, 20: PA1001, doi: 10.1029/2003PA000995.

van Leeuwen, R.J.W., Beets, D.J., Bosch, J.H.A., Burger, A.W., Cleveringa, P., van Harten, D., Herngreen, G.F.W., Kruk, R.W., Langereis, C.G., Meijer, T., Pouwer, R., de Wolf, H., 2000, Stratigraphy and integrated facies analysis of the Saalian and Eemian 
sediments in the Amsterdam-Terminal borehole, the Netherlands. Geologie en Mijnbouw/Netherlands Journal of Geosciences, 79, 161-196.

van der Hammen, T., Wijmstra, T.A., Zagwijn, W.H., 1971. The floral record of the Late Cenozoic of Europe. In: Turekian, K.K. (ed.), The Late Cenozoic Glacial Ages. pp. 392121. Yale University Press, New Haven, London.

Vangengeim, E. A., 2010. Evolution of views on Quaternary stratigraphic scales worked out in the Geological Institute, Russian Academy of Sciences. Stratigraphy and Geological Correlation 18(6), 674-684.

Walker, M.J.C., Gibbard, P.L., Lowe, J. 2015. Comment on "When did the Anthropocene begin? A mid-twentieth century boundary is stratigraphically optimal" by Jan Zalasiewicz et al. (2015), Quaternary International, doi. ????

Walker, M., Johnsen, S., Rasmussen, S.O., Steffensen, J.P., Popp, T., Gibbard, P., Hoek, W., Lowe, J., Bjorck, S., Cwynar, L., Hughen, K., Kershaw, P., Kromer, B., Litt, T., Lowe, D.J., Nakagawa, T., Newnham, R., Schwander J., 2009. Formal definition and dating of the GSSP (Global Stratotype Section and Point) for the base of the Holocene using the Greenland NGRIP ice core and selected auxiliary records. Journal of Quaternary Science 24, 3-17.

Walker, M.J.C., Berkelhammer, M., Björck, S., Cwynar, L.C., Fisher, D.A., Long, A.J., Lowe, J.J., Newnham, R.M., Rasmussen, S.O., Weiss, H., 2012. Formal subdivision of the Holocene Series/ Epoch: a discussion paper by a Working Group of INTIMATE (Integration of ice-core marine and terrestrial records) and the Subcommission on Quaternary Stratigraphy (International Commission on Stratigraphy). Journal of Quaternary Science 27, 649-659.

Walsh, S.L., 2006. Hierarchical subdivision of the Cenozoic Era: A venerable solution, and a critique of current proposals. Earth-Science Reviews 78, 207-237.

Walsh, S.L., 2008. The Neogene: Origin, adoption, evolution, and controversy. EarthScience Reviews 89, 42-72.

Waters, C.N., Syvitski, J.P.M., Gałuszka, A., Hancock, G.J., Zalasiewicz, J., Cearreta, A., Grinevald, J., Jeandel, C., McNeill, J.R., Summerhayes, C., Barnovsky, A., 2015. Can environmental radiogenic signatures define the beginning of the Anthropocene Epoch? Bulletin of Atomic Scientists 71, 46-57.

Woldstedt, P., 1962. Über die Bennenung einiger Unterabteilungen des Pleistozäns. Eiszeitalter und Gegenwart 3, 14-18.

Wolff, E.W., 2011. Greenhouse gases in the Earth system: a palaeoclimate perspective. Philosophical Transactions of the Royal Society A 369, 2133-2147. 
Wolff, E.W., Spahni, R., 2007. Methane and nitrous oxide in the ice core record. Philosophical Transactions of the Royal Society A 365, 1775-1792.

doi:10.1098/rsta.2007.2044

Zachariasse, W.J. 2001. Editorial. December 2001. Subcommission on Neogene Stratigraphy. http://www.geo.uu.nl/sns/newsletters/2001Editorial.htm

Zagwijn, W.H. 1963. Pollen-analytic investigations in the Tiglian of the Netherlands. Mededelingen van de Geologische Stichting, Nieuwe Serie 16, 49-71.

Zalasiewicz, J., Waters, C.N., Williams, M., Barnosky, A.D., Cearreta, A., Crutzen, P., Ellis, E., Ellis, M.A., Fairchild, I.J., Grinevald, J., Haff, P.K., Hajdas, I., Leinfelder, R., McNeill, J., Odada, E.O., Poirier, C., Richter, D., Steffen, W., Summerhayes, C., Syvitski, J.P.M., Vidas, D., Wagreich, M., Wing, S.L., Wolfe, A.P., An, Z., Oreskes, N., 2015a. When did the Anthropocene begin? A mid-twentieth century boundary level is stratigraphically optimal. Quaternary International (this volume).

Zalasiewicz, J., Waters, C.N., Williams, M., Barnosky, A.D., Cearreta, A., Crutzen, P., Ellis, E., Ellis, M.A., Fairchild, I.J., Grinevald, J. Haff, P.K., Hajdas, I., Leinfelder, R., McNeill, J., Odada, E.O., Poirer, C., Richter, D., Steffen, W., Summerhayes, C., Syvitski, J.P.M., Vidas, D., Wagerich, M., Wing, S.L., Wolfe, A.P., Zhisheng, A., Oreskes, N. 2015b. Disputed start dates for Anthropocene. Nature 520, 436. doi:10.1038/520436b

Zalasiewicz, J., Waters, C.N., Barnosky, A.D., Cearreta, A., Edgeworth, M., Ellis, E.C., Gałuszka, A., Gibbard, P.L., Grinevald, J., Hajdas, I., Ivar do Sul, J., Jeandel, C., Leinfelder, R., McNeill, J.R., Poirier, C., Revkin, A., Richter, D.deB., Steffen, W., Summerhayes, C., Syvitski, J.P.M., Vidas, D., Wagreich, M., Williams, M., Wolfe, A.P. 2015c. Colonization of the Americas, 'Little Ice Age' climate, and bomb-produced carbon: their role in defining the Anthropocene. The Anthropocene Review 1-11. DOI: ????

Zeuner, F.E., 1935. The Pleistocene chronology of central Europe. Geological Magazine $72,350-376$.

Zeuner, F.E., 1959. The Pleistocene Period. Hutchinson, London, pp. 447.

\section{FIGURE CAPTIONS}

Fig. 1. Southern and central Italy showing the location of ratified GSSPs and proposed or suggested GSSPs, as well as other sites discussed in the text. Monte San Nicola= GSSP for Gelasian Stage, Pleistocene Series, Quaternary System. Vrica = GSSP for Calabrian Stage. Montalbano Jonico and Valle di Manche $=$ proposed GSSP for Middle Pleistocene Subseries GSSP. Fronte section = suggested GSSP for Late Pleistocene Subseries GSSP. 
Fig. 2. The current official time scale for the Quaternary, as sanctioned by the International Union of Geological Sciences (IUGS), including both ratified and suggested and proposed GSSPs. No subseries for the Pleistocene or Holocene have yet been ratified.

Fig. 3. The geological time scale for the Quaternary, from the year 2000 to the present ratified time scale. a) IUGS-sanctioned time scale of Remane (2000), which became the "status quo" option during ICS voting in 2009. b) geological time scale with the Quaternary excluded as a formal unit, as proposed by Gradstein and Ogg (2004) and Gradstein et al. (2004, 2005), but appearing in Gradstein et al. (2005) as an informal unit. c) compromise scheme proposed by Pillans (2004) and Pillans and Naish (2005). d) scheme proposed by the ICS during the Leuven workshop in 2005, following Aubry et al., 2005 but excluding the Tertiary. e) scheme proposed by Head et al. (2008a), reflecting the "Quaternary" proposal but acknowledging the existence of the Tertiary System/Period. f) proposal submitted by the Subcommission on Neogene Stratigraphy during ICS voting in 2009. g) alternative scheme submitted by the Subcommission on Neogene Stratigraphy in their proposal (see also Aubry et al, 2005; Aubry et al., 2009, text-fig. 1) but not included on ballot. h) scheme advanced by the Subcommission on Quaternary Stratigraphy (SQS) from 2004 and INQUA from 2006 and proposed by SQS during ICS voting in 2009. This became the official (IUGS-ratified) version of the geological time scale for the Quaternary in 2009. The Calabrian Stage GSSP was to be ratified later, in 2011 (Cita et al., 2012).

Fig. 4. The Monte San Nicola section, near Gela, in Sicily. The GSSP for the Gelasian Stage, Pleistocene Series, and Quaternary System is placed at the base of the marly layer overlying the sapropelic "Nicola bed", indicated by an arrow. The GSSP has an age of 2.58 Ma. Photograph courtesy of John Clague.

Fig. 5. Detail of the sapropelic "Nicola bed" at the Monte San Nicola section, near Gela, in Sicily. The GSSP for the Gelasian Stage, Pleistocene Series, and Quaternary System is placed at the base of the overlying marly layer, as indicated by an arrow. The GSSP has an age of $2.58 \mathrm{Ma}$. Photograph courtesy of John Clague.

Fig. 6. The Vrica section near Crotone, Calabria, southern Italy. The GSSP for the Calabrian Stage and former GSSP of the Pleistocene Series. The GSSP is placed at the base of the marine claystone conformably overlying sapropelic bed 'e', indicated by an arrow in the closeup of the section in (b). Photograph by Ilka Von Dalwigk (June, 2000); supplied by Luca Capraro.

Fig. 7. The "Ideale section" at Montalbano Jonico, Basilicata, southern Italy, a GSSP candidate for the Middle Pleistocene Subseries. Shown are the volcaniclastic layers V3 $(801.2 \pm 19.5 \mathrm{ka})$ and V4 $(773.9 \pm 1.3 \mathrm{ka})$ and the position of maximum flooding. Photograph by MJH (October, 2014).

Fig. 8. A panorama of the Valle di Manche section, near San Mauro Marchesato, Calabria, southern Italy, a GSSP candidate for the Middle Pleistocene Subseries. The 
position of the "Pitagora ash" is shown by the arrow. Photograph by MJH (October, 2014).

Fig. 9. The Valle di Manche section showing the "Pitagora ash", a marker horizon for the Matuyama-Brunhes boundary with is within $0.5-1.0 \mathrm{~m}$ of this bed. The "Pitagora ash" is a redeposited layer, and about $3.5 \mathrm{~cm}$ thick at this locality. Photograph by MJH (October, 2014).

Fig. 10. A typical outcrop of the Lower-Middle Pleistocene Kazusa Group in the Boso Peninsula, Japan. Photograph by MJH (January, 2011).

Fig. 11. The Fronte section, in the vicinity of Taranto, Apulia, southern Italy, a suggested GSSP for the Upper Pleistocene. Here, last interglacial marine deposits unconformably overly Middle Pleistocene (MIS 13, 500 ka) blue clay. Photograph by MJH (October, 2014).

Fig. 12. The Fronte section, in the vicinity of Taranto, showing Upper Pleistocene molluscs and the "cushion coral" Cladocora caespitosa characteristic of the warm-water "Senegalese" fauna. Photograph by MJH (October, 2014).

Fig. 13. The Holocene GSSP in the NGRIP ice core from Greenland: a) is an enlargement of b) at the critical GSSP. The image is reversed so that impurities in the ice, including dust particles from eastern Asia, appear white. Annual banding is visible in the ice. Note a sharp increase in annual ice-layer thickness above the GSSP. The primary guide is a sharp decline in deuterium excess values (not visible), and the GSSP is dated at 11,700 calendar yr b2k with a maximum counting error of $99 \mathrm{yr}(2 \sigma)$. A break in the ice core, just above the red box in (b), has been masked out but represents continuous deposition. Modified from Walker (2009, fig. 4).

\section{TABLES}

Table 1. Requirements for a GSSP as broadly relevant to the Quaternary System, based on the revised guidelines issued by the ICS (Remane et al., 1996, based on Cowie et al., 1986 and Salvador, 1994. p. 90, 91) that remain the primary authority.

1. Best possible record of the relevant marker events - especially the primary event, but also any relevant auxiliary markers, in order to achieve maximum correlation potential.

2. Exposure over an adequate thickness of sediments - this will allow an adequate number of auxiliary markers to be recognized in relation to the boundary.

3. Continuous sedimentation - there should be no gaps, condensation, or mass flows, close to the boundary. 
4. The rate of sedimentation should be sufficiently high to separate successive, including near-contemporaneous, events.

5. Absence of synsedimentary and tectonic disturbance - so as to facilitate unambiguous interpretation of the sedimentary sequence both vertically and laterally.

6. Absence of metamorphism and strong diagenetic alteration - to allow the recognition of primary geochemical and paleomagnetic signals, relatively free from serious overprinting.

7. Abundance and diversity of well-preserved fossils throughout the critical interval. Diverse biotas will offer the best possibility of precise correlations, and therefore an open-marine continental shelf setting is best as both oceanic and neritic species, and indeed pollen and other small fossils washed in from rivers may co-occur, allowing the integration of multiple marine and terrestrial records. The presence of oceanic species is important because they are more likely to have global geographic ranges useful for long-range correlation.

8. Absence of vertical litho- or biofacies changes at or near the boundary. This minimizes the risk of a break in sedimentation, and also the risk that a local paleoenvironmental perturbation is responsible for a biofacies change. Deeper-water settings are therefore favourable.

9. Non-biostratigraphic methods of correlation have seen great progress in recent years and should be given more weight than biostratigraphic methods when choosing boundary levels and type-sections.

10. Radiometric dating - whenever possible, a GSSP should be amenable to direct quantitative calibration, such radiometric dating of an interbedded ash layer at the GSSP.

11. Magnetostratigraphy - a paleomagnetic reversal is a desirable feature of any GSSP because it potentially allows precise correlation both in marine and terrestrial sequences, and even in ice cores using the ${ }^{10} \mathrm{Be}$ flux as proxy for paleomagnetic field intensity (e.g. the Matuyama-Brunhes boundary in the EPICA Dome C Antarctic ice core; Dreyfus et al., 2008).

12. Astrochronology - it is highly desirable, in the Quaternary record at least, for a GSSP to be tuned to the orbital time scale. Records amenable to tuning may include sedimentological cycles such as sapropels in the eastern Mediterranean, physical properties such as magnetic susceptibility, geochemical cycles such as the $\delta^{18} \mathrm{O}$ record from benthic foraminifera, and biostratigraphic cycles as revealed, for example, by repetitive changes in assemblage compositions.

13. Chemostratigraphy - in addition to its use in astrochronology, the chemostratigraphic record may yield secular excursions of direct or indirect global correlative value. An example would be the sharp increase in deuterium excess values in 
the Greenland NGRIP ice core that serves as the primary guide to the base of the Holocene (Walker et al., 2009).

14. Intensive research - the section should be well studied, with the results published in the peer-reviewed literature (and preferably international literature), allowing the GSSP to have maximum utility for local, regional, and global correlation.

15. Accessibility - a GSSP should normally be easily accessible, both physically and politically, for all stratigraphers regardless of nationality. It should be available for responsible re-sampling by bona fide geologists.

16. Protection - the GSSP should be protected from degradation and development so that it can continue to serve its purpose as a standard reference indefinitely.

Notes:

1. Not every global stratotype section will meet all requirements. Common sense and experience usually determine what compromises can be made in order to avoid eternalizing the search for the perfect section. With younger parts of the time scale, there may have been insufficient time for a relatively deep-sea section to become uplifted as a subaerial exposure. The placement of the Holocene GSSP in an ice core is partly for this reason.

2. The International Stratigraphic Guide (Hedberg, 1976, p. 82; Salvador, 1994, p. 88) notes specifically with regard to Quaternary chronostratigraphic units that while the basic principles should be the same as for older Phanerozoic deposits, certain methods used for time correlation, e.g. climatic, paleomagnetic, and isotopic, may be given greater emphasis.

Table 2. Milestones in the recognition and (re-)definition of the Quaternary System/Period.

1759 Quaternary introduced as a "fourth order" (quarto ordine) by Giovanni Arduino.

1829 The term Quaternaire applied by J. Desnoyers for deposits younger than the "older Tertiary" of the Seine (Paris) Basin.

1830 Quaternaire considered by M. de Serres as synonymous with the term Diluvium, and humans contemporaneous with these deposits.

1833 Quaternary defined on paleontological grounds by H. Reboul.

1839 Pleistocene introduced informally by Charles Lyell on biostratigraphic grounds: considered equivalent to older strata of Desnoyers' Quaternary.

1840 New Glacial Theory proposed by Louis Agassiz.

1851 The term "Neogene" is coined by M. Hörnes.

1854/56 Quaternary is defined and subdivided by A. Morlot on the basis of glaciation. 
$194818^{\text {th }}$ International Geological Congress in London: Pliocene-Pleistocene and Tertiary-Quaternary boundaries linked to one another and to climatic deterioration in the Italian Neogene succession.

$198211^{\text {th }}$ INQUA Congress in Moscow, the Vrica section approved to define the Neogene-Quaternary boundary.

1985 Vrica GSSP established to define the base of the Pleistocene.

1989 Quaternary appears on an ICS/IUGS-sanctioned global stratigraphic chart (Cowie and Bassett, 1989).

1996 GSSP for the Gelasian Stage ratified as the highest stage of the Pliocene.

1999 Pleistocene GSSP reaffirmed at Vrica by IUGS EC following ICS minority vote: 10-year moratorium on Pliocene-Pleistocene boundary.

2000 Quaternary appears on an IUGS-sanctioned global stratigraphic chart (Remane, 2000).

2001 Attempts to subsume SQS within SNS.

2002 SQS re-established as an ICS subcommission independent of INQUA.

2004 Quaternary ommitted from the Geologic Time Scale 2004, ostensibly issued under ICS but breaching ICS's own statutes.

2004 INQUA EC expresses interim preference for the Quaternary to remain as a period/system.

2004 SQS business meeting at the 32nd International Geological Congress in Florence affirms prevailing support for the Quaternary as a system/period.

2004 ISSC email survey similarly affirms support for the Quaternary as a system/period.

2004 Joint ICS-INQUA Task Group formed.

2005 Joint ICS-INQUA Task Group meeting in Cambridge achieves broad consensus that the Quaternary should have full system status, and begin at 2.6 Ma.

2005 Joint ICS-INQUA Task Group report recommends that the Quaternary should begin at 2.6 Ma and have the rank of System or Sub-erathem.

2005 INQUA EC responds that only the rank of System, above the Neogene, is acceptable. It requests the establishment of a joint ICS-INQUA working group to lower the base of the Quaternary, with two options for the Pleistocene.

2005 ICS workshop in Leuven agrees to Quaternary as a formal chronostratigraphic unit with a base at 2.6 Ma but at the rank of Sub-erathem. Submits recommendations to INQUA EC and IUGS EC.

2006 INQUA EC having canvassed its members declares that 1) the Quaternary must be full formal chronostratigraphic unit at the rank of Period, 2) the base of the Quaternary should be defined by the Gelasian Stage GSSP and 3) base of the Pleistocene should be lowered to 2.6 Ma, coincident with that of the Quaternary boundary, allowing for a 10-year statutory moratorium ending in 2009. This is INQUA's final (and SQS's consistently-held) position.

2006 IUGS EC rejects ICS recommendations. Enforces status quo of Quaternary as period starting at $1.8 \mathrm{Ma}$. ICS urged to maintain dialogue with INQUA.

2007 IUGS EC rebukes ICS for procedural irregularities, and withholds financial support to ICS.

2007 ICS holds new ballot, approves SQS-INQUA position without regard to the 10year moratorium, and submits recommendation to IUGS EC. 
2007 IUGS EC accepts recommendation for Quaternary as period/system but cites procedural irregularities regarding other recommendations.

$200717^{\text {th }}$ INQUA Congress in Cairns, Australia, unanimously endorses the SQSINQUA position.

2008 Stanley Finney takes the helm as new chair of ICS.

2008 Joint ICS-IUGS open discussion meeting on the Quaternary at the $33^{\text {rd }}$ International Geological Congress (IGC) in Oslo.

2008 "Quaternary" proposal submitted by Phil Gibbard and Martin Head was based on the SQS-INQUA position. A "Neogene" counterproposal submitted by Fritz Hilgen and colleagues splits the Pliocene Series into two series named Lower Pliocene and Upper Pliocene, with the later comprising the Gelasian Stage, and the Quaternary is changed in rank to subsystem.

2008 Both proposals voted upon and overwhelmingly approved by respective subcommissions.

2009 ICS conducts intense open discussion via email and the ICS website.

2009 SNS submits rebuttal of "Quaternary" proposal (Appendix 1) to ICS, Martin Head and colleagues representing SQS respond to rebuttal (Appendix 2), these effectively representing closing arguments for SNS and SQS.

2009 Just prior to voting, SNS asks ICS to modify its proposal, but request denied.

2009 ICS holds ballot on 1) the "Quaternary" proposal, 2) the "Neogene" proposal, and 3) the status quo. Only the "Quaternary" proposal achieves a supermajority. A second round of voting considering the "Quaternary" proposal alone achieves an $89 \%$ (supermajority) approval.

2009 IUGS EC ratifies "Quaternary" proposal. Statutory 10-year moratorium begins.

\section{APPENDICES}

Appendix 1. Response by the ICS Subcommission on Neogene Stratatigraphy to the "Quaternary" proposal (published in Gibbard and Head, 2009a, box 1), dated 17 February 2009.

The case for compromise: coping with the destabilizing impact of the Quaternary as a standard chronostratigraphic unit.

Dr Stan Finney, Chair International Commission on Stratigraphy

Dear Stan,

This is in response to the request by the Subcommission on Quaternary Stratigraphy, submitted on September 1, 2008, to define the Quaternary in a GSSP at the base of the Gelasian Stage, and furthermore to move the base of the Pleistocene to coincide with this. You also have in hand an alternative proposal from our Subcommission for a compromise that minimizes the disruption created by imposing this antique and fundamentally irrelevant term on the established chronostratigraphy. We feel that without such a compromise, the only alternative is complete exclusion of the Quaternary from the formal time scale (Gradstein, et al., 2004). There are three main problems with the SQS 
request:

1. The SQS request violates the basic principle of hierarchical definition, in creating a boundary for the Quaternary a priori, and then requiring that the Pleistocene, a supposedly basic component, be redefined to fit the preconceived boundary.

2. The SQS request, in proposing a formal GSSP in the marine type section of the Gelasian, justifies this as conforming to a concept for the Quaternary that is expressly rooted in evidence for a traditionally favored climate change in continental lithostratigraphy. This is wholly irrelevant to the standard time scale, which is based on the paleontology of marine deposits. The imposition of the incongruous Quaternary boundary in the relationship proposed by SQS needlessly disrupts standard chronostratigraphy and has a destabilizing effect on the literature.

3. The SQS request fails to recognize that despite a loose consensus following the 1948 IGC, the marine-defined Pleistocene has not been formally established as a hierarchical component of the climate-defined Quaternary (point 1). On the contrary, various formalistic definitions of the Quaternary put forth by SQS and INQUA omit consideration of the Pleistocene, except after the fact, and focuses on the exclusive paleoclimatic meaning instead. The System/Period status of the Quaternary claimed by SQS, which leads to so much conflict, is not justified.

In recognition of the importance of the field of Quaternary studies, and with a sincere desire to end the endless controversy and discord, we have suggested that the Quaternary can be accommodated in a compromise that gives it formal status, with the characteristics and boundary desired by the leaders of the Quaternary community. We sincerely trust that the advantages of such a compromise will be honestly considered.

We would like to take the opportunity below, to address the 13 points advanced by our colleagues Phil Gibbard and Martin Head in support of the SQS request.

Point 1. While the concept of the Quaternary was already recognized by Arduino as the fourth and youngest subdivision of the geological succession in the Apennines (1759/1760), the term Quaternary was not formally introduced until 1829 by Desnoyers for a stratigraphic interval (e.g., marine and fresh water deposits of Touraine and Languedoc region of western France) that approximately corresponds with the current Neogene (Berggren and Van Couvering, 1982; Berggren, 1998). It was immediately modified by de Serres (1830) to refer to Diluvial deposits only. Quaternary, like Tertiary, originated in the outdated Neptunian system that recognized the age of rocks by their degree of lithification - in fact it is still the case that unconsolidated alluvium is automatically mapped as Quaternary. Paleogene and Neogene are subdivision of the stratigraphic record based on paleontology. The two models are unrelated, and precedence is thus irrelevant. The terms Tertiary and Quaternary may predate Paleogene and Neogene, but so also Primary and Secondary predate Paleozoic and Mesozoic.

Point 2. The step by step lowering of the base of the Quaternary over the past decades (see our Fig. 2) has reflected shifting ideas in the Quaternary community as to where the 
traditional concept of "first glacial climate" should be identified. That there is a present consensus in this regard does not validate this procedure of starting with a preconceived idea and looking for its stratigraphic manifestation. It is inconsistent with first chronostratigraphic principles in which boundaries are objectively derived from stratigraphic features.

Point 3. While Walsh (2008) made the point that Hörnes did not include strata of Recent age in the Neogene, he also admitted (ibid., p. 51) that among the various "Newer Pliocene" deposits that Hörnes specifically did include were some that are now considered to be early, middle, and possibly even late Pleistocene in age, in the heart of the same time interval ascribed to Quaternary paleoclimates. More to the point, Walsh stated that the "meaning of almost all standard global geochronologic names have evolved since they were first used, and whatever Moriz Hörnes' original meaning of the Neogene was, this original meaning is fundamentally irrelevant to the modern classification of the Cenozoic" (italics ours). While Walsh used this line of reasoning to dismiss the case for the current use of Neogene by the marine community, he should have recognized that it applies with equal force to the case for the current use of Quaternary. In other words, if original definitions are irrelevant, the fact that the "first glaciation" is the traditional criterion for the beginning of the Quaternary does not justify an inflexible adherence to this characterization if it conflicts with an otherwise well-established and functional consensus.

Point 4. Our proposal does not treat the Holocene as a subdivision of the Pleistocene, although that has been a valid option in the past.

Point 5. The Vrica GSSP, contrary to the SQS assertion, is in fact widely correlated (cf. Van Couvering, 1997), in close association with the top of the Olduvai Chron and significant faunal changes in the marine and continental realms (not least the earliest Homo, at Olduvai Gorge itself). As for it being arbitrarily selected, the program to define the base of the Pleistocene in a physical reference point was set in motion by the 1948 resolution and continued for over 40 years (!!!) in IGCP 41 , as detailed in the volume cited above. Whether this level is associated with a climatic change greater or less than that evidenced at the Gelasian GSSP, or indeed at any other level in the Neogene, is irrelevant under the principles of chronostratigraphy.

Point 6. We accept that the base of the Quaternary is now defined at 2.6 (2.588) Ma, while noting that the placement of the boundary is plainly a matter of taste. The phrase "first climatic deterioration", as the basis for the present discussion, was introduced in the resolution of the 1948 London IGC. However, the phrase does not refer to the Italian Pliocene-Pleistocene but to the Italian Neogene (King and Oakley, 1949b). In this context the first signs of climatic deterioration are in the Miocene (i.e. Neogloboquadrina FO at $\sim 11.78 \mathrm{Ma}$ and the Globorotalia miotumida (=conomiozea) group FO at 7.25 Ma), while typical large sinistrally coiled Neogloboquadrata atlantica, cited as evidence of major deterioration at $2.72 \mathrm{Ma}$, in fact invaded the Mediterranean at $~ 7.9 \mathrm{Ma}$ as well. Prominent glacial episodes between 6.3 and $5.5 \mathrm{Ma}$ have been reported by e.g. Van der Laan et al. (2005) with amplitudes in $\delta^{18} \mathrm{O}(\max 0.8$, average $0.5 \%$ ) that are not fundamentally 
different from the amplitudes reached by Late Pliocene - Early Pleistocene glacial cycles (max 1.0, average $0.6-0.7 \%$ ). The Messinian glacials are marked by repeated invasions of sub-polar dinoflagellate assemblages into middle latitudes and ice-rafted debris, seen in North Atlantic cores. To refer to such clearly evidenced events as these, or to the Mammoth event, as "precursors" merely because climate improved afterward is disingenuous. All such events (including the Gelasian event) are cold climate maxima in a fluctuating system.

Point 7. We agree that the Monte San Nicola GSSP is widely correlatable because it is associated with a major paleoclimatic event. The Gelasian global stage was not proposed for this reason, however, but to replace the inadequate concept of the Astian with a new unit having a stratotype in direct superpositional relationship with the stratotypes of the Lower Pliocene global units in the same part of Sicily. This was done with the explicit intention of creating a unified Pliocene mega-stratotype in one marine sequence. Thus it is incongruous to reassign the Gelasian to the Pleistocene.

Point 8. The status of the Quaternary remains open for discussion, like everything else that was "prematurely decided" in 2005 and 2007. It should be stressed that the inclusive compromise of Aubry et al. (2005) was approved by ICS before being rejected by IUGS. The main objection, lack of hierarchy, has been addressed in the present proposal, but the previous compromise remains available as well.

Point 9. There is no fundamental difference between the SQS and SNS positions on the age of the base of the Quaternary, when this is defined in the Monte San Nicola GSSP.

Point 10. The standard global chronostratigraphic scale is the responsibility of ICS / IUGS. In this regard, we stress that the basic principles expressed in the ICS guidelines has to be followed in the final decision on this controversy.

Point 11. We fail to see why a Quaternary Subperiod (or Superseries) would be as disruptive as a Quaternary Period that requires decapitation of the Neogene and redefinition of the Pleistocene.

Point 12. We did not intend to have two separate time scales but, in case an inclusive solution is found undesirable, to have a separate chart for the Quaternary with its own dominantly - continental subdivision outside the global chronostratigraphic scheme. This solution refers to option 6 in Figure 1 in Pillans and Naish (2004). In our opinion such a chart can have a formal status, like any regional chart, and its basic units will exactly match the marine stages of the global chart.

Point 13. We emphasize that in contrast to the SQS proposal, we favour a solution that addresses the concerns of both the marine and Quaternary communities. We believe that it is possible to find a compromise that incorporates the Quaternary as a standard unit with the boundaries and character essentially as proposed by the SQS, while preserving the basic structure of the established Cenozoic time scale. We repeat that a rejection of such a compromise by the leaders of the Quaternary community, in favor of a rigid and 
needlessly disruptive arrangement such as the proposal submitted by SQS, will meet with little sympathy from the profession as a whole, and will unquestionably lead to a continuation of the schism that presently divides us.

We are grateful to you, and the ICS, for the opportunity to respond, and for your impartial consideration of our presentation.

Appendix 2. Rebuttal by M. J. Head and colleagues (for SQS) to the response by the Subcommission on Neogene Stratatigraphy (reproduced in Appendix 1), dated 27 February, 2009.

Prof. Stan Finney, Chair International Commission on Stratigraphy

Dear Stan:

\section{Response to objections by the SNS to the SQS proposal that the base of the Quaternary System/Period be lowered to the Gelasian Stage GSSP (at 2.588 Ma), and that the base of the Pleistocene Series be lowered to the same position}

We thank you and our colleagues in the Subcommission on Neogene Stratigraphy (SNS) for this opportunity to yet further clarify our position regarding the timing and status of the Quaternary and associated units. We are pleased to address comments raised by the SNS in their letter of 17 February 2009 in response to the proposal of the Subcommission on Quaternary Stratigraphy (SQS) dated 28 August 2008, and we briefly address proposals advanced by Aubry et al. (in press [2009]). Before doing so, however, we would like to emphasize several key points:

1. The Quaternary, which traditionally comprises Pleistocene and Holocene, has long been used in both popular and official time scales, including the current IUGSsanctioned time scale of Remane (2000; Figure 1). This time scale places the Quaternary as a period/system above the Neogene, so that the base Quaternary defines its top. Such a configuration reflects an overwhelming body of recent and historical literature (Salvador, 2006a, b), and would have been evident to anyone visiting the International Geological Congress in Oslo last summer (SQS proposal). Our proposal does not truncate the Neogene because the orthodox view it espouses has never acknowledged an extended Neogene.

2. The IUGS has already ratified the Quaternary as a period/system (IUGS email of 28 May 2007 to ICS). Contrary to assertions by the SNS and Aubry et al. (in press[2009]), the status and rank of the Quaternary are not in debate. We confine our proposal deliberately and appropriately to the position of the base Quaternary and bases of relevant subordinate units (Pleistocene Epoch/Series, Gelasian Age/Stage).

3. We propose that the base Quaternary be lowered from its present IUGS-sanctioned position (Remane, 2000) at the base Pleistocene Vrica GSSP (1.8 Ma) to the Gelasian Stage GSSP (2.588 Ma; Figure 1). This acknowledges fundamental and profound changes to Earth's climate system at around 2.6 Ma, and the manifold 
associated biotic and physical responses (Head et al., 2008a).

This lowered position can be correlated globally across and between marine and terrestrial realms. No concentration of global events occurs at the current boundary at Vrica (1.8 Ma). Understandably, the ICS has already agreed with our proposed redefinition of the base Quaternary (Ogg and Pillans, 2008), and we note that the SNS themselves "accept that the base of the Quaternary is now defined at 2.6 (2.588) Ma" (SNS letter of February 17, 2009, point 6). We therefore trust that no objections are accorded to this part of our proposal.

4. Any serious proposal must respect the hierarchical nature of the geological time scale. Accepting an age of around 2.6 Ma for the base Quaternary and utilizing a readymade GSSP (the base Gelasian GSSP), hierarchical principles demand that the base of the Pleistocene be lowered to that of the Quaternary. The Gelasian Stage then becomes the lowermost stage of the Pleistocene, and its establishment by Rio et al. (1998) effectively anticipated this outcome.

5. Users of the geological time scale must be considered, and the Quaternary community numbers 50,000 worldwide with INQUA serving as its voice. INQUA, which has equal status with the IUGS under the International Council of Science (ICSU), unanimously endorses the SQS proposal in its entirety.

Our closing remarks are given at the end of this letter, but we now take this opportunity to briefly counter the 13 points of objection listed by the SNS in their letter of 17 February, 2009.

Point 1. We make the point that the Quaternary as a general concept (Arduino, 1760) and even as a formal term (Desnoyers, 1829) is sanctioned by a long tradition of usage, with its roots predating both the Pleistocene (Lyell, 1839) and Neogene (Hörnes, 1853). The term Quaternary may be etymologically distasteful to some, but to others it is an instructive reminder that stratigraphic classification is dynamic and carries an interesting history. Similar objections might be leveled at the terms Cretaceous and Carboniferous, as these also belonged to once-popular but since abandoned lithology-based classifications (Walsh, 2006). Understandably, the terms Primary, Secondary, Oolitic, Lias and others have fallen out of service because they were not useful; whereas the Cretaceous, Carboniferous, and for that matter Quaternary and Tertiary, have survived because they clearly are (Salvador, 2006a, b; Walsh, 2006). No one would seriously try to suppress the Cretaceous or Carboniferous on grounds that these terms were "antique" or "irrelevant".

Point 2. We are pleased the SNS acknowledges that our proposal represents the current consensus, but we reiterate that this simply reflects a long-held traditional view in which the Quaternary is placed above, not alongside, the Neogene (Harland, 1989 [Harland et al., 1990]). Scientific advances often result from deductive reasoning, and this holds too for modern stratigraphy. An important event or transition in Earth history is initially recognized (often following a "preconceived idea"). The precise lithological position of the boundary (the GSSP) is then selected with due regard to the practicalities of 
correlation. This exact methodology was employed for the selection of the Gelasian Stage GSSP (Rio et al., 1998), which was championed by the SNS itself. We use this same boundary and same methodology for the base Quaternary.

Point 3. The SNS seems not to dispute the conclusion of Walsh (2008) that the notion of a Neogene extending to the present day is indeed based on flawed historical interpretation. While most standard global geochronological names have undeniably shifted from their original meaning over the centuries (Walsh, 2008), we note that the Quaternary has always extended to the present day, and has been exclusively associated with glacial conditions for at least the past 60 years, as our proposal acknowledges.

Point 4. We are pleased that the SNS accepts the decision of the IUGS and does not treat the Holocene as a subdivision of the Pleistocene.

Point 5. We strenuously uphold our assertion that the Vrica GSSP, which presently defines the base Pleistocene, is fundamentally flawed as a boundary of epoch/series rank owing to the paucity of biostratigraphic and physical events at and near the boundary. The "recognition" of this boundary owes mostly to its proximity to the top of the Olduvai Subchron, although this is a full $10 \mathrm{~m}$ above the boundary at Vrica. The boundary is even more elusive in the absence of a continuous paleomagnetic record, and especially in continental deposits, but even in high-latitude marine deposits where calcareous microfossils are sparse to absent and marine isotope stratigraphy unavailable. These deficiencies all explain the long history of dissatisfaction with the present base of the Pleistocene (e.g., Suc et al., 1997) and its continuance to the present time only by minority vote (Bowen and Gibbard, 2007). Contrary to the assertion of the SNS, the emergence of the genus Homo is not associated with the Olduvai Subchron, but dates to around ca. 2.6-2.45 Ma (Deino et al., 2006; Prat, 2007). This date is closer to our proposed redefinition of the base Pleistocene at 2.6 Ma.

Point 6. We have difficulty in understanding the SNS's objections to the placement of the base Quaternary at 2.6 Ma, when the SNS avowedly accepts this very position. The base Quaternary is coincident with the Gelasian GSSP, which the SNS states as being "widely correlatable because it is associated with a major paleoclimate event". We have already noted that cold events occur before the major onset of Northern Hemisphere glaciation. But one simply cannot compare, for example, the isolated event of Marine Isotope Stage M2, occurring as it does within an otherwise stable mid-Pliocene warm interval (e.g., Dowsett, 2007), with the intense, rapidly recurring glacial events at around 2.6 Ma. These later glacial events, and their attendant biotic and environmental manifestations, best serve as a general guide for the base Quaternary, but with the Gelasian GSSP offering the most practical actual definition. The ICS, SQS, SNS, and INQUA all agree with this placement of the base Quaternary.

With respect to the International Geological Congress (IGC) held in London, 1948, King and Oakley (1949a, b) noted that the Pleistocene should include the Villafranchian regional mammal stage. Nearly half of this stage is presently in the Pliocene, and lowering the Pleistocene to include the Gelasian Stage will bring the Pleistocene in closer agreement with the 1948 IGC decision (Ogg and Pillans, 2008). 
Point 7. Since it is agreed by ICS, SQS, SNS, and INQUA that the base Quaternary should be placed at 2.6 Ma, which coincides with the Gelasian GSSP, then the base Pleistocene must be lowered to that of the base Quaternary in order to maintain hierarchical order within the time scale (Figure 1). The Gelasian then becomes the lowermost stage of the Pleistocene. It would be incongruous and confusing to have the Gelasian Stage in the Pliocene Series and the Quaternary System.

Point 8. The status of the Quaternary is in fact closed for discussion. The "IUGS EC unanimously approves the recommendation [of the ICS] to recognize the 'Quaternary' as a formal system/period of the international geological scale" (IUGS to ICS, 28 May, 2007 [IUGS Executive Committee, 2007b]). This decision, far from being premature, resulted from long discussions between the ICS and INQUA, and was facilitated by a special joint working group established for this purpose. The duration of the Quaternary remains open for discussion, but we emphasize that ICS, SQS, and INQUA, and the SNS itself, all agree that the Quaternary should begin at 2.6 Ma.

Point 9. We are heartened that the SNS agrees with our proposal to use the existing Monte San Nicola GSSP (base Gelasian) to define the base Quaternary.

Point 10. We accept that in general terms the standard global chronostratigraphic scale is the responsibility of the ICS/IUGS. However, responsibility for the Quaternary lies jointly with the IUGS and INQUA, as they are equal Science Union members of the International Council for Science. Indeed it might be argued that INQUA has greater jurisdiction over the Quaternary, and therefore the past 2.6 million years of Earth history, because of its larger pool of expertise. In any case, it is important to note that INQUA fully endorses the SQS proposal, which we might add does follow ICS guidelines (e.g., Remane et al., 1996).

Point 11. It is disingenuous to claim that the Neogene is being decapitated. The SQS proposal merely reflects the orthodox scheme in which the Quaternary overlies the Neogene. But this is moot because the IUGS has already ratified the Quaternary as a period/system.

Point 12. We have every confidence that the ICS will reaffirm its earlier full support of the SQS proposal (Ogg and Pillans, 2008). The alternative could bring IUGS and INQUA into direct conflict, which would serve no useful purpose. We consider that the prospect of two independent time scales, one for Quaternarists and another for the remainder of the geological community, as ominously raised by Aubry et al. (in press [2009] - their invocation of the NOMA principle), would be a monumental failure of common sense and cooperation. It would be completely unacceptable to us, and no doubt also to IUGS and INQUA.

Point 13. The implication that the SQS does not address the concerns of the marine Quaternary community is fallacious. Since INQUA has a membership of around 50,000, the Quaternary community undoubtedly has many more marine geoscientists than the 
Neogene community, and much consideration of the SQS position is based on the marine record (e.g., Head et al. 2008a). The SQS and INQUA, in fact, have an uncompromising mandate to provide a solution that will satisfy marine and non-marine geoscientists alike.

\section{Closing remarks}

The SQS proposal to lower the base Quaternary to 2.6 Ma has the support not only of INQUA, but also ICS and the SNS itself. Lowering the base Pleistocene to 2.6 Ma simply follows rational and hierarchical principles: the Gelasian, Pleistocene and Quaternary all then share the same GSSP (at Monte San Nicola, 2.588 Ma). The SNS counterproposal appears driven more by desperation than logic: this may explain why just $65 \%$ of its members voted in favour of their own proposal.

The publication by Aubry et al. (in press [2009]) illustrates two muddled schemes. Both place an Early Pliocene Epoch exclusively in the Neogene, and a separate and independent Late Pliocene Epoch in a Neogene/Quaternary overlap. Thus, two Pliocene epochs are invoked with each occurring counterintuitively in a different unit of higher rank. The Piacenzian is moved from the Middle or Late Pliocene to the Early Pliocene, for which there is no modern precedent. The Quaternary is awkwardly sidelined to the rank of sub-period in one scheme and sub-era in the other, each scheme violating the recently IUGS-re-approved rank of the Quaternary as a period/system. For the Pliocene, a completely unnecessary schism is created that will only assure future confusion (Figure 1). Both Aubry et al. schemes, in their defense, acknowledge that the Quaternary can be justified only if starting at around 2.6 Ma. This one crucial point of agreement is of course the basis for the SQS proposal, and from which our own small adjustments logically follow.

Regarding the Pleistocene, this term was introduced by Lyell in 1839 to represent "ice age" deposits that postdate his already established Pliocene. Because the Pliocene was the last unit of the Tertiary, this opened the possibility for a post-Pliocene Quaternary (Harland et al., 1989 [1990], p. 68). The Pleistocene has therefore always been the lowest division of the Quaternary, the correspondence of their bases has existed for more than a century, and our proposal correctly maintains this historical relationship. The proposal by Aubry et al. (in press [2009]) places much weight on the fossil record, and we do not downplay its historical role in the creation of the time scale (although we do note that their fig. 5 suggests stronger evidence of adaptive radiation in the Quaternary than Neogene!). But ultimately, if Earth's history is to be subdivided into natural units, this requires our planet to be treated as an evolving system that includes its climate, along with other factors. We adopt this more holistic approach in acknowledging fundamental changes to planet Earth at around 2.6 Ma.

In closing, the IUGS has ratified the Quaternary as a system/period, and the lowering of the base Quaternary to $2.6 \mathrm{Ma}$ is already accepted by ICS, SNS, SQS and INQUA. Our proposal simply and rationally requests that small adjustments be made in accordance with hierarchical principles: that the base Pleistocene Epoch/Series be lowered to that of the Gelasian Age/Stage and Quaternary Period/System, with each defined/redefined by the GSSP at Monte San Nicola (dated at 2.588 Ma). We trust that the ICS will continue to support this proposal.

Martin J. Head (Brock University, Canada), Philip L. Gibbard (University of 
Cambridge, U.K.), Jan A. Piotrowski (University of Aarhus, Denmark), Mike Walker (University of Wales, Lampeter, U.K.). 